\title{
EFFECT OF MINERAL NUTRITION ON LODGING OF CEREALS
}

\author{
by E. G. MULDER *) \\ Agricultural Experiment Station and Institute for Soil Research T.N.O., \\ Groningen, the Netherlands
}

1. Introduction.

2. Experimental methods.

3. Plant characters related to tendency to lodging.

4. Effect of nitrogen nutrition on lodging and on plant characters related to tendency to lodging.

5. Effect of potassium nutrition.

6. Effect of phosphorus nutrition.

7. Effect of soil-pH.

8. Effect of soil structure.

9. Effect of lodging on yield.

10. Discussion.

11. Summary.

\section{INTRODUCTION}

In the course of an investigation into the effect of nitrogenous fertilisers on the growth and yield of cereal crops, it was observed that lodging is often the limiting factor in attaining maximal yields by increased nitrogen supply. This is particularly the case under the humid conditions prevailing in the Netherlands during the greater part of the growing season of the cereals. Although for the production of high grain yields some bending over of the ripe plants is desirable, severe lodging both from the point of view of grain formation and of harvesting is unprofitable.

In order to learn the circumstances under which lodging occurs, a number of field and pot experiments with rye, wheat, barley and oats have been carried out from 1940 to 1949. In most of the field experiments nitrogen dressings have been combined with applications of other nutrients and with variations in rate of seeding and in spacing.

Although many papers have dealt with the problem of lodging, there is considerable disagreement amongst various authors as to its cause. The first investigators who studied this phenomenon came to the conclusion

*) Agronomist of the "Landbouwkundig Bureau der Nederlandse Stikstofmeststoffenindustrie". 
that lack of silicic acid was responsible for the inadequate standing ability of cereal plants (see $S$ wi e c i cki ${ }^{34}$ )). Although the view that lodging has to be ascribed to an inadequate uptake of silicic acid may be found in a number of subsequent papers, the fact that normal cereal plants could be cultivated in nutrient solutions from which silicic acid was withheld made it clear that the Si-deficiency hypothesis was untenable.

$\mathrm{S}$ a $\mathrm{ch} \mathrm{s}^{31}$ ), $\mathrm{Koch} \mathrm{h}^{22}$ ) and many other investigators have associated tendency to lodging with etiolation of the lower internodes of the stem as a result of a high rate of seeding or high fertility, particularly abundant nitrogen. The long and weak lower internodes which resulted would have little resistance to bending as a result of which lodging of the crop would easily occur.

$\mathrm{K} \mathrm{T}$ a u ${ }^{24}$ ) who has made a very comprehensive study of lodging phenomena in cereals, admits that etiolation of the lower internodes makes the culm more liable to bending, and therefore has to be considered an important factor in causing tendency to lodging; he denies, however, that lodging occurs simply as a result of etiolation. Plants with strong stems may also lodge when their root development or the anchorage of the roots in the soil is inadequate. The view of $\mathrm{Kr}$ a $\mathrm{u}$ s concerning the importance of a well-developed root system in lodging-resistant plants is also found in some more recent papers. $\mathrm{C}$ a $f \mathrm{f}$ e $\mathrm{y}$ and $\mathrm{C}$ a $r \mathrm{rol} \mathrm{l}^{8}$ ) who have investigated a number of oat varieties for various characters related to tendency to lodging came to the conclusion that a large proportion of well-developed, strong, unbranched anchor roots extending horizontally through the soil may provide the best possible anchorage for the plants. In addition to such a root system, lodging-resistant plants should have sturdy lower stems.

The view that both strength of straw and development and anchorage in the soil of the root system are important factors in procuring a strong standing ability of cereal crops is found in a number of papers ( $\mathrm{H}$ a n l e y ${ }^{20}$ ) $\mathrm{H}$ alli d a ${ }^{18}$ ), $\mathrm{H}$ a $\mathrm{mil}$ t o $\left.\mathrm{n}^{19}\right)$ ). The latter has made a comprehensive study of the root development of eight oat varieties possessing a different degree of lodging resistance. Varieties with a high degree of resistance were generally found to produce large, widely spreading and rigid coronal roots. Varieties which lodged easily were found to possess smaller and more flexible roots, which had a greater tendency to grow downward in the sqil. It is difficult, however, to decide to what extent the resistance to lodging of these oat varieties has to be attributed to the development of their root systems since the latter was found to be significantly correlated with the diameters of the lower parts of the culms.

Many authors have investigated resistance to lodging in connection with the breeding of new varieties of cereals. They have studied various plant characters in relation to resistance to lodging with the purpose of making use of these characters in isolating varieties with a high standing ability. This is of particular importance to those breeders who are working in regions where lodging does not occur regularly. There is, however, decided disagreement between various authors as to the relative importance of various plant characters as an index for lodging resistance. This is largely due to 
the fact that a considerable amount of the variation in these characters found in a population of different strains has to be ascribed to environmental influences. Apparently the intervarietal differences between most plant characters related to lodging resistance have only a relative value. When the growing conditions have been changed these differences also may undergo considerable change. $\mathrm{Bra} \mathrm{d}^{6}$ ) measured a number of plant characters of three oat varieties differing in resistance to lodging. It was found that the variety having the greatest standing ability had the shortest lower internodes, the thickest fifth internode, the thickest culm wall, the greatest number of vascular bundles, the greatest thickness of thick-walled tissue and the thickest sclerenchyma cell walls. Although these findings may demonstrate the importance of many attributes in strengthening the culm of oat plants, according to $\mathrm{B} \mathrm{r} \mathrm{a} \mathrm{d} \mathrm{y}$, these characters cannot be used as an absolute index for lodging resistance since they appear to be variable under the influence of various growing conditions. In agreement with $\mathrm{G}$ a $\mathrm{rber}$ and $\mathrm{Olsen}{ }^{12}$ ) the thickness of the sclerenchyma cell walls was found to be the most independent of soil variations. Even this characteristic, however, was considered too unstable a factor to be of use as an absolute criterion of the lodging-resistant ability of a variety.

According to $\mathrm{Sal} \mathrm{mon}^{32}$ ) breaking strength of the straw may be used as an index for resistance to lodging. It would be even a better measure of tendency to lodging than lodging itself since the latter is closely related to the occurrence of adverse weather conditions. Davis and Stanto ${ }^{10}$ ) found a relatively. good agreement between standing ability of oat varieties in the field and breaking strength of the straw. $\mathrm{C} \mathrm{Ia} \mathrm{r} \mathrm{k} \mathrm{and}$ Wils o $\left.{ }^{9}\right)$, however, were unable to find a correlation between lodging index and breaking strength of the culms in field experiments including 24 varieties of summer wheat and 17 varieties of barley. They obtained a significant correlation between diameter of culm and breaking strength. A tkin s$\left.{ }^{2}\right)^{3}$ ) found no significant correlation between lodging and breaking strength of the straw. Nevertheless he believed that breaking strength determinations can be used to predict lodging behavior in the field and consequently can be used in a breeding programme to isolate lodging-resistant strains. Breaking strength of the straw was found to be closely correlated with culm diameter and with weight per unit length of culm at the base of the plants in wheat. Since the latter can be determined more easily than breaking strength, this author substituted weight per unit length of culm for breaking strength determinations as a measure of lodging resistance. $\mathrm{V}$ a $\mathrm{n} \mathrm{D}$ o b b e $\mathrm{n}^{37}$ ) obtained a poor correlation between weight of basal culm and lodging resistance of a number of varieties of barley, oats and wheat.

Albre $\mathrm{cht}^{1}$ ) found no correlation between breaking strength of the straw and length of the internodes in wheat plants. The former was found to be positively correlated with culm diameter, weight per unit length of culm and wall thickness of the culms. The positive correlation between strength of straw and thickness of sclerenchymatous ring was much less close than that between strength of straw and development of vascular 
bundles. Culm wall thickness and relative development of vascular bundles were considered by this author to be the most important attributes in connection with resistance to lodging. According to $\mathrm{M} \mathrm{ol} \mathrm{d} \mathrm{e} \mathrm{n} \mathrm{h}$ a w e $\mathrm{r}^{25}$ ) lodging-resistant varieties of wheat have a greater number of vascular bundles than varieties which lodge easily. This does not agree with the results obtained by $\mathrm{C}$ a f $\mathrm{fre}$ and $\mathrm{C}$ a r roll who found more vascular bundles in an oat variety which was very liable to lodge than in one which had a high resistance to it. $\mathrm{H}$ a $\mathrm{m} \mathrm{i} 1 \mathrm{t}$ o $\mathrm{n}^{19}$ ) found the greatest number and size of vascular bundles in lodging-resistant oat varieties.

Welto ${ }^{38}$ ) and Welto $\mathrm{W}$ and $\mathrm{Morr}$ is ${ }^{39}$ ) ascribe lodging to a low weight of dry matter per unit length of culm. This may result from a relatively low content of lignin and other carbohydrates and a high water content or from the development of slender culms. According to $\mathrm{H}$ a $\mathrm{m}$ ilt $O n^{19}$ ) a lodging index of a particular variety must include diameter of culm, root type and height of the plant, the relative importance of these characters being given numerically as $10: 5: 1$.

Droogleever Fortuyn-van Leyden ${ }^{11}$ ) studied lodging phenomena in seven rice varieties. She concluded that in addition to a well-developed root system and strong longer internodes the development of a strong leaf sheath enveloping the internodes may be a valuable character in procuring standing ability. In some rice varieties with weak stems the strongly developed leaf sheaths enabled the plants to remain in an upright position until harvest time. This statement is in agreement with an earlier communication by $R$ a miah and $D h$ a rmalin$\mathrm{g}$ a $\left.\mathrm{m}^{29}\right)$. Furthermore these authors stress the importance of diameter of culm internodes and thickness of culm wall in securing lodging resistance in rice plants. $\mathrm{Riv}$ e $\mathrm{r} \mathrm{a}^{30}$ ) ascribes the inadequate standing ability of plants supplied abundantly with nitrogen to the high water content of their culms.

With regard to the effect of mineral nutrition on lodging resistance there is agreement amongst various authors as far as the influence of nitrogen supply to the plants is concerned. Excessive amounts of available nitrogen in combination with favourable growing conditions often lead to the formation of a heavy crop possessing a high tendency to lodging. As far as the cause of this nitrogen effect is concerned, however, the opinions of various authors differ considerably. According to $\mathrm{K} \mathrm{r}$ a u s${ }^{24}$, the great increase in weight of the higher parts of plants supplied with excessive nitrogen is often the cause of the increased liability to lodging. In addition the lower internodes may be weakened owing to reduced wall thickness and reduced thickening and lignification of the mechanical tissues of the culm. The latter is in agreement with the results obtained by $\mathrm{K}$ is sel12), Welto ${ }^{38}$ ) and $W e 1$ to $n$ and $M \circ r$ is ${ }^{39}$ ). The former found a reduced cell wall thickness in oats and grasses treated with nitrogenous fertilisers. The effect was more pronounced in the parenchyma than in the sclerenchyma tissues and more so with nitrate than with ammonium nitrogen as the fertiliser. W e I to n found that oat plants grown on a fertile soil, rich in available nitrogen, had thinner culm walls and a less completely 
lignified sclerenchymatous ring. In accordance with these structural differences the content of carbohydrates, including lignin, was found to be lower in the lodged plants. In contrast to these results, $\mathrm{Ph}$ illips et: al. ${ }^{27}$ ) found a higher lignin content in the straw of lodged wheat plants dressed with sodium nitrate than in straw from non-lodged control plants which had not been fertilised with nitrogen. According to these authors a high lignin content makes the stems less resistant to lodging.

$\mathrm{Purvis}{ }^{28}$ ) investigated the effect of potassium deficiency on the standing ability and the anatomy of the stem of Dactylis glomerata. The strengthening effect of potassium was found to be very pronounced. Frequently the grass on plots without a $\mathrm{K}$-dressing was completely flattened, whereas that on the neighbouring plots supplied with potassium was still standing. In contrast to the strengthening of the plants, the thickening of the sclerenchyma cell walls in the stems was not favoured by an improved K-nutrition. The sclerenchyma walls were thinner where potassium had been supplied especially during the eariy stages. Apparently the rigidity of the plants well-supplied with potassium was not the result of anatomical strengthening. $\mathrm{Tu} \mathrm{b} \mathrm{b} \mathrm{s}{ }^{96}$ ) found potassium-deficient barley plants to have much weaker lower internodes than plants which had been fully manured. P-deficient plants and particularly those with nitrogen deficiency had the strongest lower internodes. This was concluded from measurements of the force required to crush $1 \mathrm{~cm}$ length of straw. In agreement with these measurements the culm wall thickness of the lower internodes of potassium-deficient plants was found to be much less than that of fully manured plants. The thickness of the sclerenchymatous ring of $\mathrm{K}$-starved plants was practically unchanged in comparison with normal plants but a striking reduction of lignified parenchyma was found in the former plants. $\mathrm{Krantz}$ and $\mathrm{Chand} 1$ er ${ }^{23}$ ) found that potassium dressings decreased lodging in corn (maize) only in those cases where visual symptoms of $\mathrm{K}$ deficiency occurred in the undressed plants.

$\mathrm{K}$ is s e $\mathrm{l}^{21}$ ) observed a thickening effect of phosphate dressings on cell walls in oats and in two grasses.

The lodging of cereals due to fungal attack (Cercosporella herpotrichoides) was not considered in the present investigations. When the density of the crop is not too great, nitrogen dressings may enable the plants to partly overcome the detrimental effect brought about by this fungus (B o c km a $\left.n n^{4}\right)$ ). Care was taken to ensure that the crops in which lodging phenomena were studied were free from Cercosporella attack.

\section{EXPERIMENTAL METHODS}

Experiments were laid out on various soils in the northern part of the Netherlands. The cereals were sown at the rate of approximately $100 \mathrm{~kg}$ per ha in the case of oats and barley and $150 \mathrm{~kg}$ per ha in the case of rye and wheat. The spacing was generally $20 \mathrm{~cm}$; in 
some experiments various spacings have been used. Nitrogen was applied in different amounts, usually in the form of ammonium nitrate limestone. In those cases in which no interactions between nitrogen and other nutrient elements were to be studied, the whole area was amply dressed with phosphate, potassium and in some instances with magnesium and copper. Where the effect of phosphorus, potassium and other elements in relation to nitrogen nutrition on lodging were to be studied, the experiments were laid out on soils poor in these elements.

Degree of lodging has been recorded as a lodging index ranging from $0-10$. These indices were obtained by multiplying area of lodged crop by degree of lodging $(0=$ erect, $10=$ total area completely flattened).

In order to determine the effect of excessive amounts of nitrogenous fertilisers on various plant characters, independent of lodging, part of the crop on some plots was supported by ropes so that the plants were forced to keep their upright position (see Plate 1).

- In some cases use was made of pot experiments for studying the effect of different fertiliser treatments in combination with different degrees of illumination.

For the measurement of various plant characters in relation to tendency to lodging samples of from 50 to 100 culms per plot were collected at different stages between flowering and ripening. For this purpose the plants were dug out of the soil in such a way that the upper parts of the roots remained attached to the base of the culm. No attempt was made, however, to collect the whole root system. The samples were used for measuring a number of plant characters such as length and diameter of internodes, weight per unit length of culm, and thickness of culm wall, thickness and lignification of sclerenchymatous ring, wall thickness of sclerenchymatous cells and number of vascular bundles. The latter characters were measured microscopically in hand-prepared cross sections cut from the middle portions of the second lowest internodes. To weaken the lignified tissues the straws were boiled in water for 15 minutes. They were stained by phloroglucinol and hydrochloric acid.

In those cases in which the relation between lodging and root development were to be studied, a method employed by Dr M. A. J. Goed ewa g e e ${ }^{14}$ ) ${ }^{15}$ ) of this station was followed. A pit was dug approximately one meter deep and half a meter wide. A board 90 
by $30 \mathrm{~cm}$ and studded with pins $8 \mathrm{~cm}$ long and $5 \mathrm{~cm}$ apart, was then pushed into the vertical wall of the pit. The soil was cut $1 \mathrm{~cm}$ beyond the end of the pins after which the slab of soil containing the roots of approximately ten cereal plants was carefully dug out and removed to the laboratory. Because of the pins the soil could be washed away . without altering the natural structure of the root system.

\section{Analytical methods}

Lignin was determined according to a modified method of $\mathrm{K} \mathrm{I}$ a s o $\mathrm{n}$ (cf $\left.\mathrm{Bra} \mathrm{un}^{7}\right)$ ). $1 \mathrm{~g}$ of ground straw was weighed into a flask of 11 capacity. To this $20 \mathrm{cc}$ of 80 percent sulphuric acid was added and the mixture was allowed to stand at $20^{\circ} \mathrm{C}$ for 30 minutes with occasional stirring. The mixture was then diluted with water to $500 \mathrm{cc}$ and boiled gently for a further 30 minutes to complete hydrolysis of carbohydrates. The residue was filtered on a weighed filter in a Büchner funnel, washed free of acid with 11 hot water, treated once with acetone, dried, weighed and ashed. A second sample treated in a similar way was used for determining nitrogen. Lignin was calculated on an ash-free and protein-free basis. In some cases the ground material was refluxed for 8 hours with a mixture of two parts ethanol and one part benzene, followed by an extraction with water of $60^{\circ} . \mathrm{C}$ during 24 hours (cf Gos s and P hilli $\mathrm{p} \mathrm{s}^{17}$ )).

\section{PLANT CHARACTERS RELATED TO TENDENCY TO LODGING}

Lodging of cereals often results from the combined effects of an inadequate standing power of the crop and adverse weather conditions prevailing during some part of the period from ear emergence to ripening. When growing conditions during the period of stem elongation have been favourable for the development of plants with a great tendency to lodging, these plants may remain erect if, during the subsequent two months, there is no heavy rain and wind. On the other hand plants relatively resistant to lodging may fall down when exceptionally bad weather prevails from flowering to ripening.

From these considerations it will be seen that tendency to lodging is not identical with lodging itself. Since the grower can influence the liability of a crop to lodging but not the weather conditions, it is clear that investigations concerning the effect of various conditions on lodging have to consider tendency to lodging rather than lodging itself. This applies particularly to those regions where rainy weather does not prevail regularly between ear emergence and ripening of the cereals. In the Netherlands as in other regions with a marine 
climate where such weather is very common during July and August, tendency to lodging will often result in the cereal crop falling down. There are exceptions, however, and the author has therefore investigated the effect of a number of nutritional conditions on lodging itself as well as on a number of plant characters closely related to tendency to lodging. Before discussing the relative value of these plant characters as a measure for tendency to lodging, a short description will be given of the structure of the culm of cereals *).

Generally the culm of cereals is a hollow cylinder consisting of from 5 to 7 internodes. The length of these internodes is smallest at the base of the culm; it increases considerably towards the top. Although from the point of view of resistance to bending it is most desirable that the lower internodes have the greatest diameter, very often this is not the case. The highest and the lowest internodes have generally the smallest diameter. The wall thickness and the degree of lignification, however, have their greatest development in the lower parts of the stem.

The leaf sheaths which surround a considerable part of the internodes presumably play an important role in strengthening the stem particularly when the tissues are still green and weak. This does not apply to the lower internodes, the sheaths of which wither at an early stage.

Anatomically the culm internodes consist of the following tissues:

a) The epidermis.

b) A zone of sclerenchymatic tissue beneath the epidermis, called "hypoderm" by some authors ${ }^{28}$ ). The lignified fibres have narrow lumina and strong walls. The number of lignified cells as well as the wall thickness is variable.

c) Embedded in the sclerenchymatous ring are bands of green assimilating parenchyma which run parallel along the stem.

d) Large-celled ground parenchyma extending from the sclerenchymatous ring to the central cavity. The walls of these parenchymar cells are sometimes lignified.

e) Vascular bundles. There exist two types of vascular bundles, viz. small ones which are situated in a ring in the sclerenchymatous tissue whilst nearer to the centre in the parenchyma large bundles are found, arranged more or less regularly in a ring.

As has been stated earlier, lodging may occur as a result of irreversible bending or breaking of the lower internodes or of uprooting i.e. bending or breaking of the roots. Although the author has observed in some cases, particularly following heavy rain storms, that lodging of cereals was due to uprooting without any bending of the stems,

*) For a more detailed description of the culn of wheat plants see P er c i v a ${ }^{26}$ ).

Plant and Soil $\mathrm{V}$ 
in by far the majority of cases irreversible bending of the stem at its lower internodes was found to be associated with the lodging of the crop. Sometimes a combination of bending of the lower internodes and of bending and breaking of the roots may be found to occur in lodged cereals (see also $\mathrm{K} \mathrm{r}$ a u s${ }^{24}$ )).

From these considerations it may be seen that the tendency of a crop to lodging depends on one or more of the following three characteristics:

a. Resistance of the culms to bending. This applies particularly to the lower internodes which have to resist the greatest moment of force.

$b$. The development of the root system and its anchorage in the soil. A culm highly resistant to bending may be useless in preventing lodging if its roots are weakly developed.

c. Weight of the higher internodes of the stems plus leaves and heads in relation to the length of the culms. The heavier the higher parts of the stem and the greater the distance from their centre of gravity to the base of the culm the greater the moment of the forces acting upon the lower internodes and the roots.

\section{a. Resistance of the culm to bending}

The resistance to bending of a culm internode depends to a large extent on its diameter and wall thickness. Since the diameter of the lower internodes is often correlated negatively with its length, the latter characteristic likewise has been studied in relation to liability to lodging. It should be stressed, however, that the length of the lower internodes as such has no effect on its resistance to bending.

Further characteristics of the culm which may be considered to be highly important in connection with tendency to lodging are the structure and chemical composition of the culm wall. The occurrence of a sclerenchymatous ring in the outer layer of the stem undoubtedly contributes materially to the strength of the culm. Since the number of lignified cells as well as the wall thickness of these cells varies considerably under the influence of external conditions, much attention should be paid to these characters in relation to tendency to lodging. The number of vascular bundles and their structural composition as well as the lignification of the ground parenchyma also may be related to the strength of the culm. 


\section{b. Root development and tendency to lodging}

Lodging-resistant crops should have, in addition to sturdy lower stems, a large proportion of strongly developed coronal roots which extend more or less horizontally through the soil. Roots with a greater tendency to grow downward in the soil are of less importance in this respect ${ }^{8}{ }^{19}$ ).

\section{c. Weight of higher internodes, leaves and head}

Whether the tendency to lodging is due to an inadequate resistance of the lower internodes to bending or to a poorly developed or poorly anchored root system, in both cases it will be affected adversely by a heavy weight of the upper parts of the plant. This weight. may be considerably increased by adhering rain water. W e 1 t o $n$ and $\mathrm{Mor} r$ is ${ }^{39}$ ) found that in oat plants this may amount to approximately one-fifth of their own green weight.

\section{EFFECT OF NITROGEN NUTRITION ON LODGING AND ON PLANT CHARACTERS RELATED TO TENDENCY TO LODGING}

\section{a. Nitrogen mutrition and lodging}

The effect of nitrogen nutrition on the lodging of cereals has been investigated in a number of field experiments laid out on different soils during the years 1940 to 1949. A considerable increase in lodging was observed in most cases when the nitrogen nutrition of the plants had been more excessive (Fig. 1). This is in agreement with practical experience and with the results of many experiments described in the literature.

On different soils and in different years, however, the resalts were not identical. This was partly due to differences in soil fertility, particularly in available soil nitrogen and moisture supply, and partly to differences in climatic conditions. Soils rich in available nitrogen require less fertiliser nitrogen to produce a heavy crop with a great tendency to lodging than do poor soils. In addition to the nitrogen supply of the crop, favourable climatic conditions during the period of elongation of the basal culm internodes of the cereals are required for the production of plants with a great liability to lodging. If during this period the weather is very dry or cold the rate of growth of the plants is reduced as a result of which tendency to lodging is low while lodging itself even at excessive nitrogen levels 
does not usually occur. Such conditions, which may be common in regions with a dry climate, are relatively exceptional in the Netherlands. They may be found more frequently on high sandy

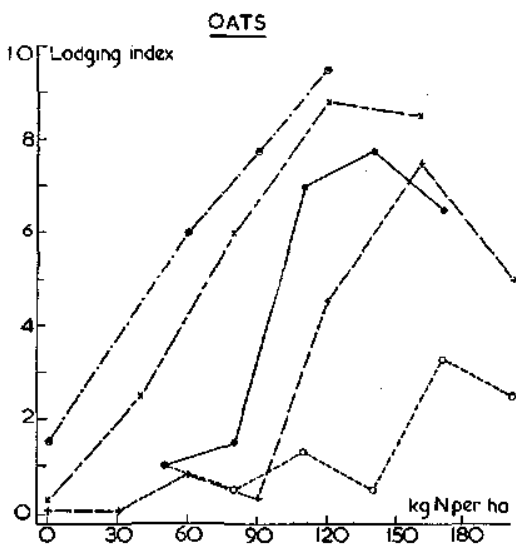

- Exp.590, July6.1940

- 598. . 23. .

- Exp.611, July 25,1941

+ . 595, Aug 6.1941
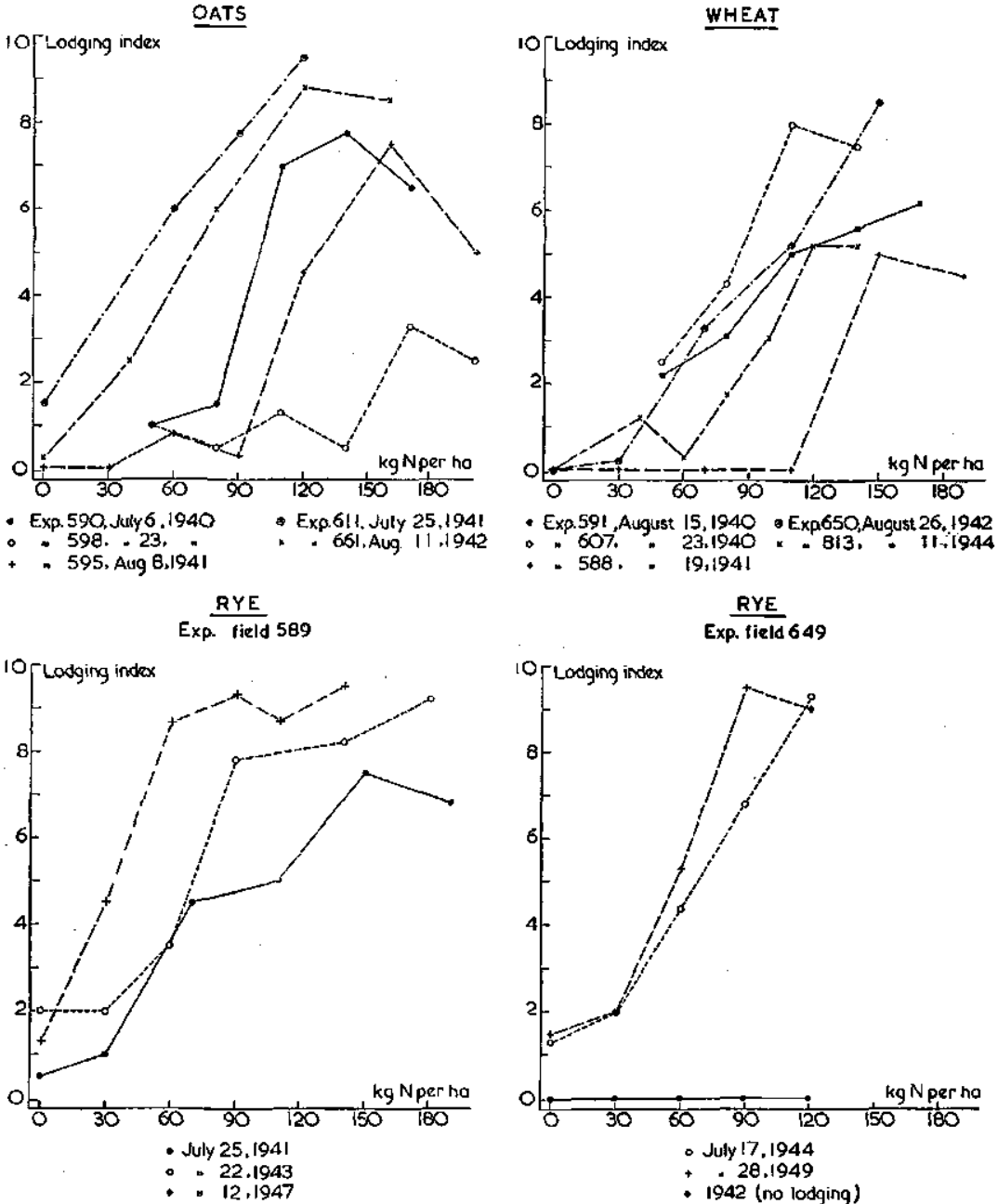

. 588. : 19,194

RYE

Exp. tield 649

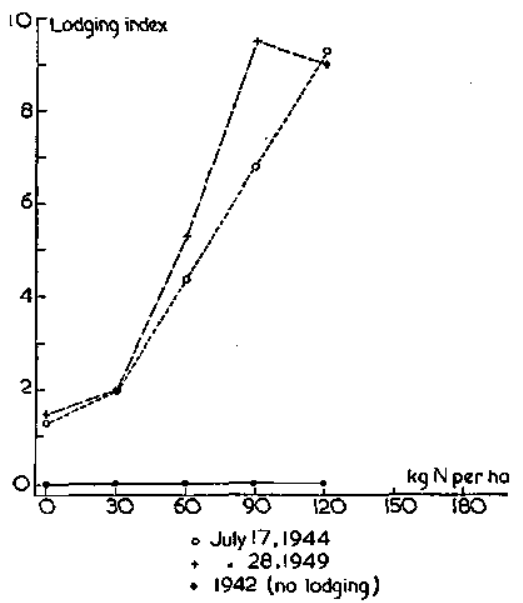

Fig.1. Effect of nitrogen dressings on lodging of oats, summer wheat and winter rye. $0=$ erect, $10=$ completely flattened.

soils with a poor water-holding capacity than on peaty and clay soils. The oats on Experimental plot 598 suffered from such a drought period in 1940 and practically no lodging occurred even at a 
dressing of $200 \mathrm{~kg} \mathrm{~N}$ per ha (Fig. 1). On Exp. plot 590, however, where the plants did not suffer from shortage of water in 1940, the crop was almost completely lodged when $110 \mathrm{~kg}$ of nitrogen per ha or more had been applied.

\section{OATS}
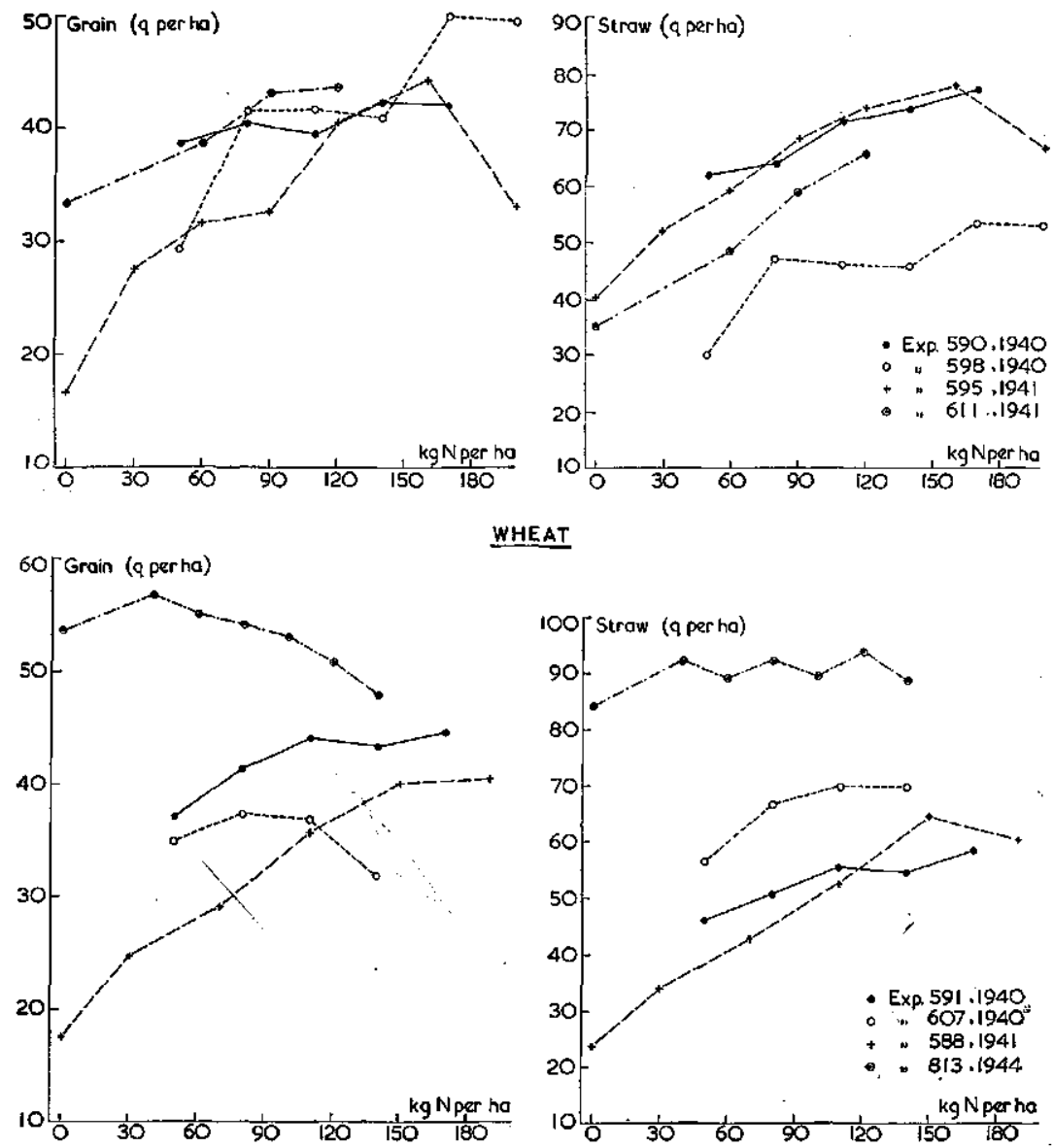

Fig. 2. Effect of nitrogen dressings on yield of oats and"wheat $(1 \mathrm{q}=100 \mathrm{~kg})$.

When the drought period is of a short duration, as was the case with Exp. 598, grain production may not be reduced appreciably. Straw production on this plot, however, was much lower than that on Plot 590, where the grain production suffered seriously from 
lodging (Fig. 2). When the drought period persists for a longer period of time, however, the grain yield will be considerably lower.

The important effect of climatic conditions on lodging may be RYE

Exp.fietd 589
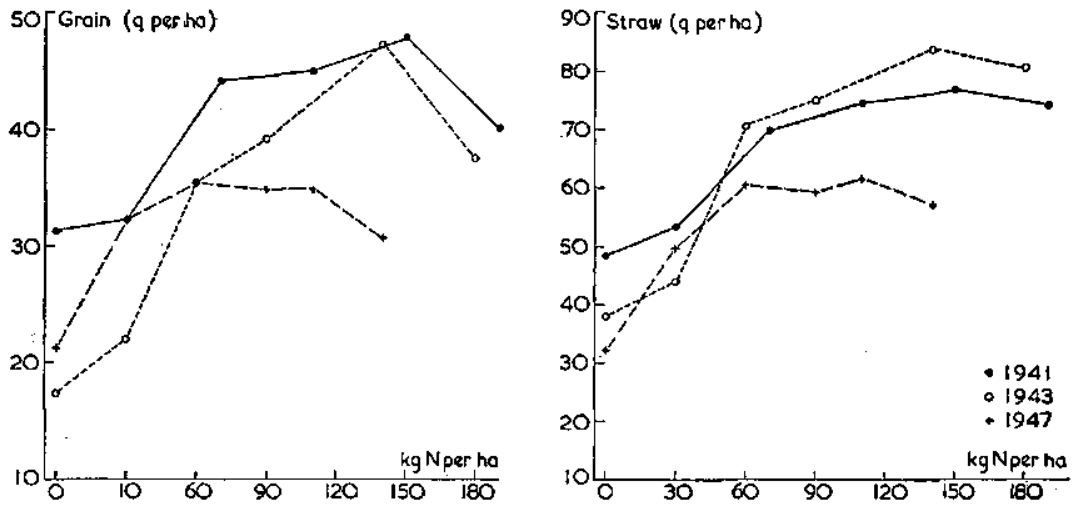

Exp. field 649
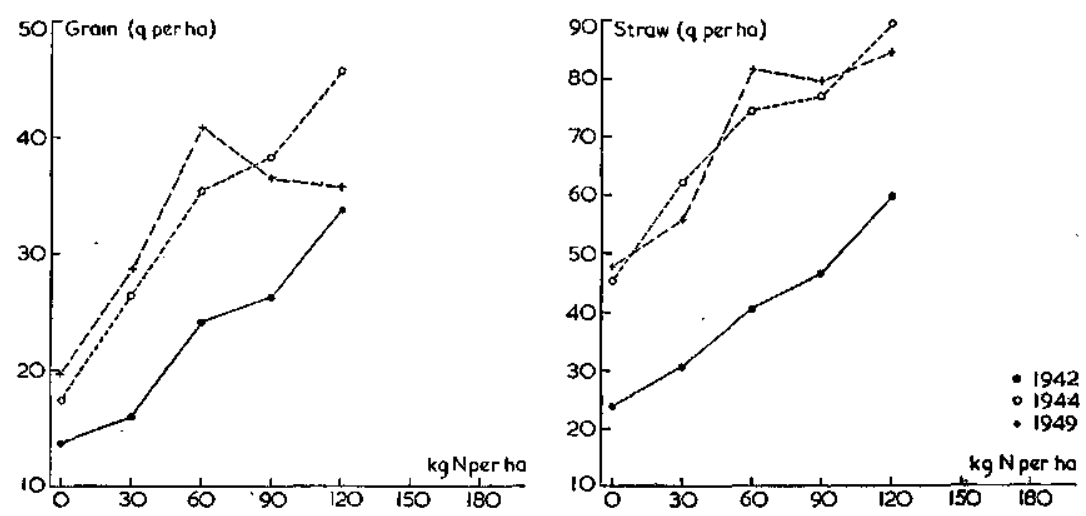

Fig. 3. Effect of nitrogen dressings on yield of rye $(1 \mathrm{q}=100 \mathrm{~kg})$.

seen particularly from those experiments in which the same cereal was cultivated on the same area in different years (Experiments 589 and 649 in Fig. 1). The large differences in lodging of rye observed on these plots may have been due to differences in weather 

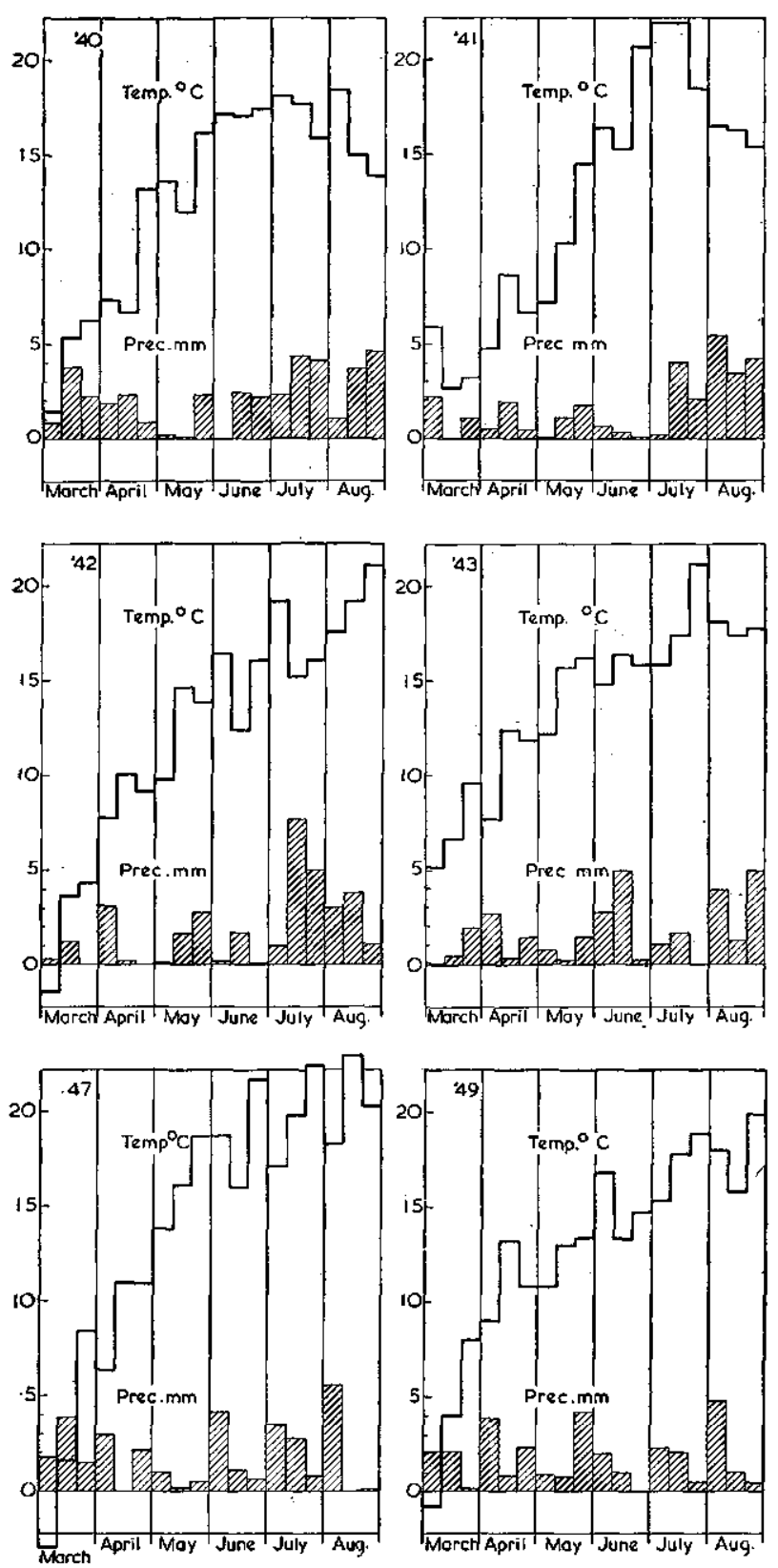

Fig. 4. Average daily temperature and average daily precipitation per 10 days in different years. 
conditions during the growing period of the crops resulting in plants with a widely varying liability to lodging. They may also have been caused, however, by differences in weather conditions between blooming and ripening. Heavy rain storms during this period may beat down crops which under more favourable weather conditions would have remained erect.

On Plot 649 the absence of lodging in 1942 was apparently a result of the very dry spring, with no rain between April 10 and May 10 (cf Fig. 4). As a result the crop responded inadequately to the nitrogen dressings which had been applied on April 17. The rain storms which occurred rather frequently in 1942 were unable to bring about lodging of the crop.

In the case of Plot 589 the severe lodging of the crop in 1947 apparently resulted from both a relatively high tendency to lodging due to favourable growing conditions in the spring and a heavy thunderstorm on June 5 .

A further factor which may be responsible for the differences in lodging in different years is the amount of available soil nitrogen which may vary under the influence of temperature and rainfall in the preceeding months. From the course of the yield curves in Fig. 3 it could be concluded that the rye of Plot 649 in 1942 was supplied less abundantly with soil nitrogen than in 1944 and 1949.

\section{b. Effect of nitrogen nutrition on plant characters related to tendency to lodging}

1. Length of internodes. One of the plant characters which have been studied extensively in relation to lodging is the length of the various internodes of the culm. It is a well-known fact that etiolated plants form long, slender and weak stems. Since nitrogen nutrition promotes the stooling of cereal plants and the formation of leaf material, it will bring about a considerable shading of the lower parts of the stem.

For the measurements of the internodes samples of from 50 to 100 culms from plots dressed with different amounts of fertiliser nitrogen were collected at various times between flowering and ripening. In some cases samples have been taken from lodged and non-lodged areas of the same plot or from general fields. The results of these determinations are given in Table 1 and in Fig. 5. Since the number of internodes of the various culms of the samples varied 
from five to seven, or sometimes eight, average values have been calculated of culms with equal numbers of internodes.

It should be stressed that the length of the internodes has been

RYE

Exp. field 649. 1949

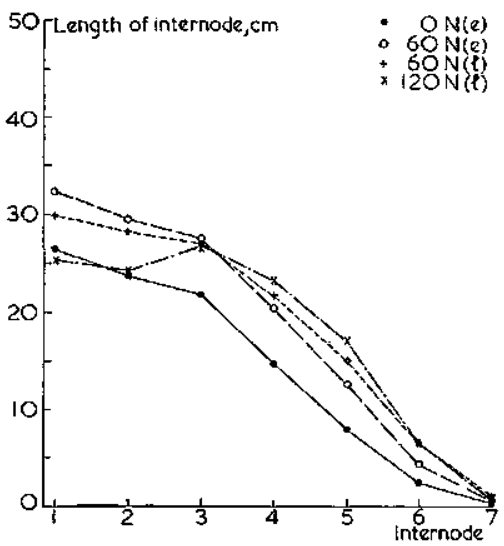

WHEAT

Exp. field 650,1942

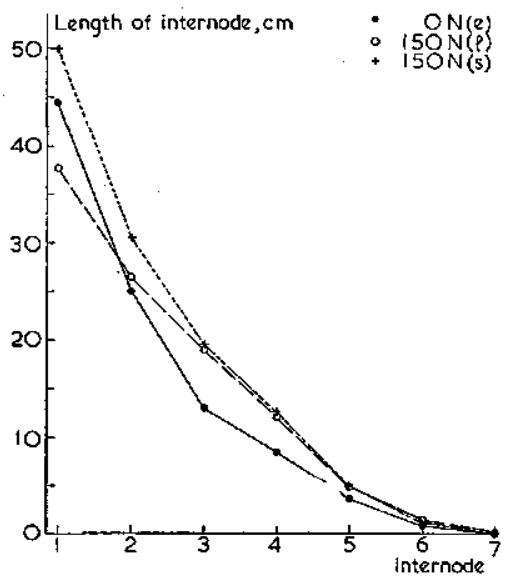

WHEAT

Exp. field 607,1940

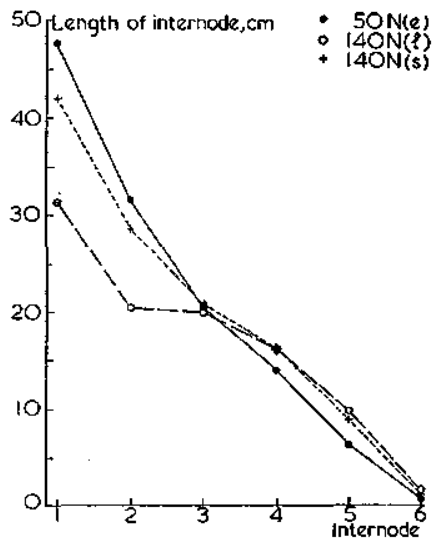

WHEAT

Gen. field 1943

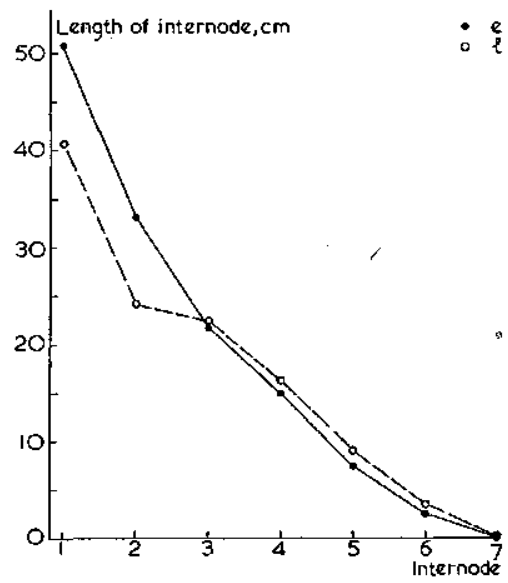

Fig. 5. Length of internodes of cereal culms at different nitrogen dressings. $\mathrm{e}=$ erect, $\mathbf{l}=$ lodged, $\mathrm{s}=$ supported plants, 1 st $=$ highest internode.

ascertained with the naked eye, so that values which could not be easily measured in this way, viz. those shorter than $2-3 \mathrm{~mm}$ were 


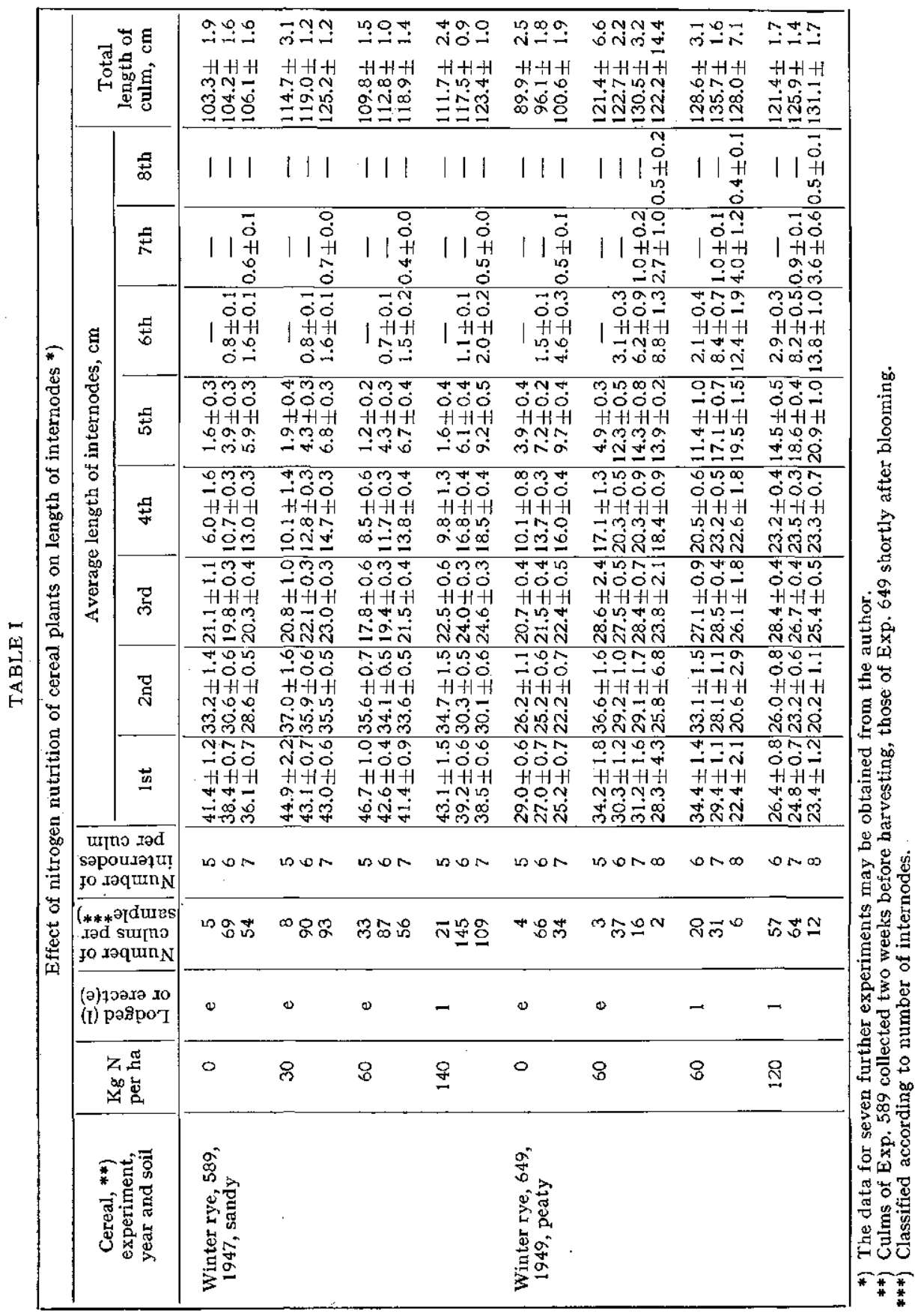


omitted. Had a more accurate measurement been possible, the number of internodes in all culms of a particular crop would probably have been the same. Under certain circumstances the lower internodes may reach measurable lengths, in other cases they remain very short or even rudimentary. Since it is highly probable that culms of the latter type have very compact and sturdy basal parts, attention has been paid to the relationship between number of internodes and nitrogen nutrition.

The results of the measurements show that plants with an excessive nitrogen supply and which in general are very liable to lodge, have longer lower internodes than those grown on the same field with a low or moderate nitrogen supply (see also Fig. 5) *).

It is remarkable that the upper two internodes of plants wellsupplied with nitrogen are frequently considerably shorter than those of plants dressed with moderate amounts. This is particularly true when lodging has occurred at an early date. When plants with a high liability to lodging had been supported by ropes so that they remained erect (Plate I) the upper internodes attained a normal length. This clearly shows the inhibiting effect of lodging on the growth of the upper internodes. The lower internodes of these supported plants, however, had approximately the same length as those of the lodged plants, indicating that the relatively long lower internodes of the latter plants was not a result of lodging.

The negative correlation between length of lower and higher internodes may likewise be found more or less clearly in unlodged plants. This will be seen when plants grown in a greenhouse are compared with those grown outdoors (cf Fig. 6). The former have longer lower internodes but shorter higher ones. It may also be concluded from the fact that plants with a larger number of measurable internodes have the shortest upper internodes (Table I). In the latter case it is assumed that an increase in the number of internodes simply means an elongation of the lowest so enabling them to be measured.

*) Since the number of measurable internodes is frequently higher when the nitrogen supply to the plants has been more abundant (see Table I), it will be clear that the differences in length of lower internodes between plants with varying nitrogen supply, will become more pronounced when average values for all plants in one sample have been calculated. In this case the assumption has been made that the number of internodes in all cuims of a certain variety is constant. In Figs. 5 and 6 these average values have been plotted. 
When a comparison is made between the lengths of the lower internodes of plants grown under various climatic conditions

\section{RYE}
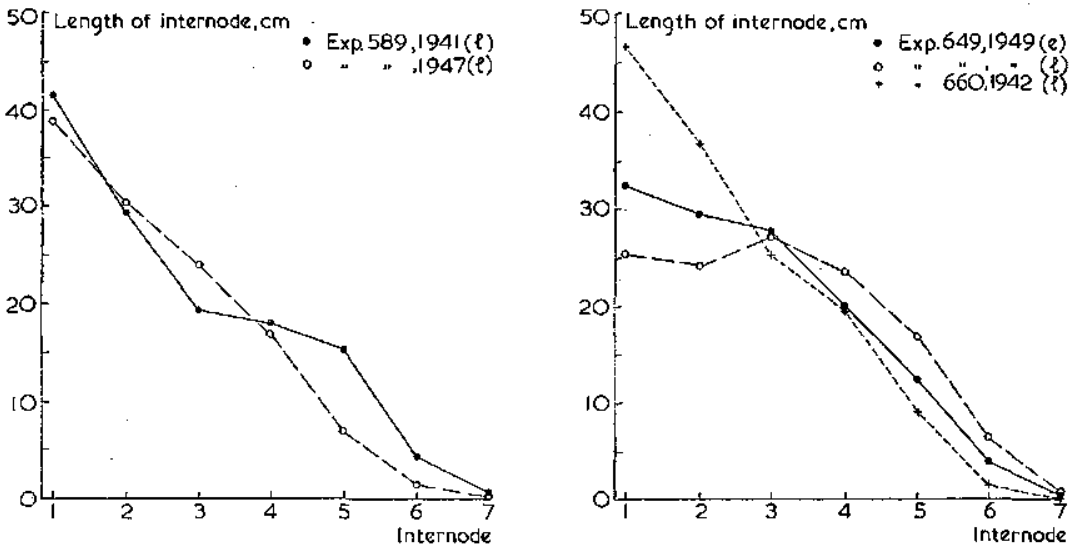

WHEAT

OATS
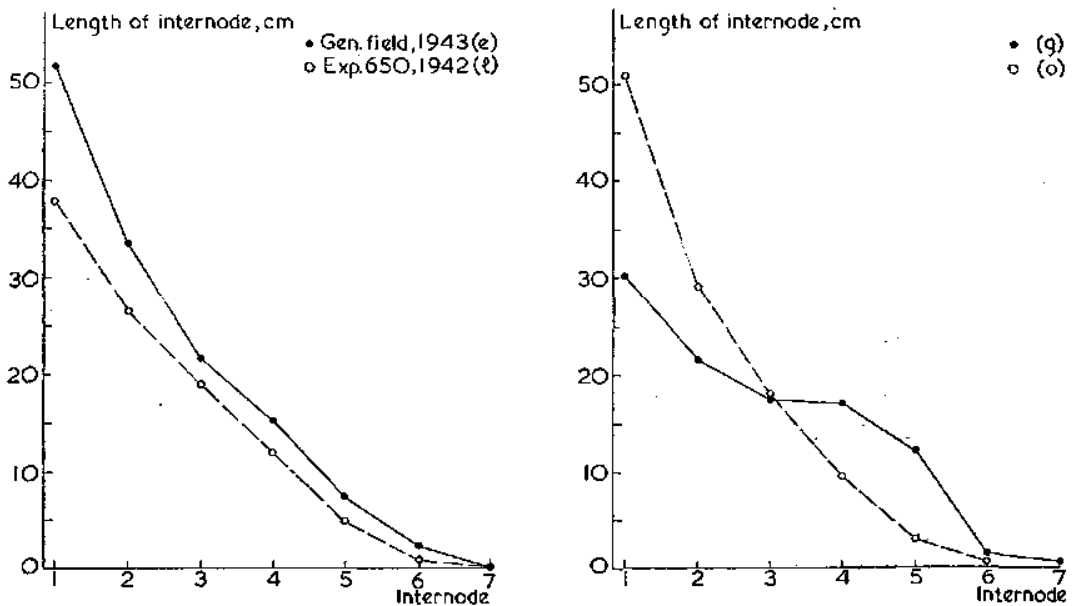

Fig. 6. Length of internodes of cereal culms at different nitrogen dressings. $\mathrm{e}=$ erect, $\mathrm{l}=$ lodged, $\mathrm{g}=$ grown in a greenhouse, $\mathrm{o}=$ grown in the field, Ist $=$ highest internode.

(different years, greenhouse as compared with field conditions) it will be seen that the differences between these plants are sometimes 
of much more importance than those found in plants of the same field grown at varying nitrogen levels. In the experiments with rye it was found that the length of the 5th and 6th internodes from plants grown in 1941 (Exp. 589) was more than twice the length of corresponding internodes from plants grown on the same field in 1947 (cf Fig. 6). In 1949 (Exp. 649) the length of the 6th internodes of lodged plants was four times the length of similar internodes in 1942 (Exp. 660). In the former year even the lowest internodes showed a considerable elongation. Since the spring of 1949 was characterized by exceptionally warm weather (cf Fig. 4) it is highly probable that the very rapid growth of the cereal plants which was further promoted by a favourable water and nitrogen supply in many fields has resulted in long, weak, lower internodes which had little resistance to bending. In this year lodging occurred in practically every rye field in the Netherlands.

Similar differences in the length of the lower internodes were found in the experiments with oats and wheat. Plants grown in a greenhouse had usually considerably longer lower internodes than those grown in the field (see Fig. 6). This is probably due to the higher temperature and somewhat reduced illumination under greenhouse conditions.

Although the long lower internodes of plants grown at high temperatures and with favourable water and nitrogen supplies are undoubtedly a valuable indication of the weakness of those plants, the data of Fig. 6, however, clearly show, that the length of these internodes cannot be used as a general index for liability to lodging. The lodged rye plants of Exp. 660 in 1942 for instance had considerably shorter lower internodes than the non-lodged plants of Exp. 649 in 1947. Similarly the erect wheat plants of the 1943 experiment had considerably longer lower internodes than the lodged plants of Exp. 650 in 1942. Apparently the long lower internodes of the erect plants had more resistance to bending than the relatively short ones of the lodged plants. Differences in root development and weight of heads and leaves may also have played a part in affecting the liability to lodging.

2. Number of internodes. Although it is not known whether plants with a greater number of internodes are more liable to lodging than those with a relatively small number, it is probable that the latter plants have more sturdy basal parts so that they 
have a greater resistance to lodging than those with a higher number. From the results of Table I it can be seen that favourable growing conditions, particularly nitrogen supply, may promote the number of internodes measurable with the naked eye.

RYE

Exp. field 649,1949

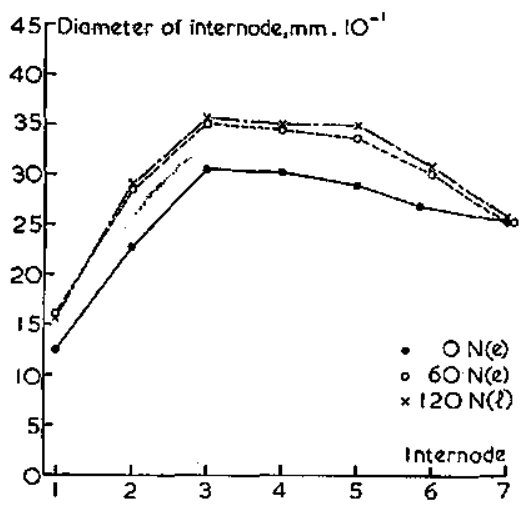

Exp. field 589,1947

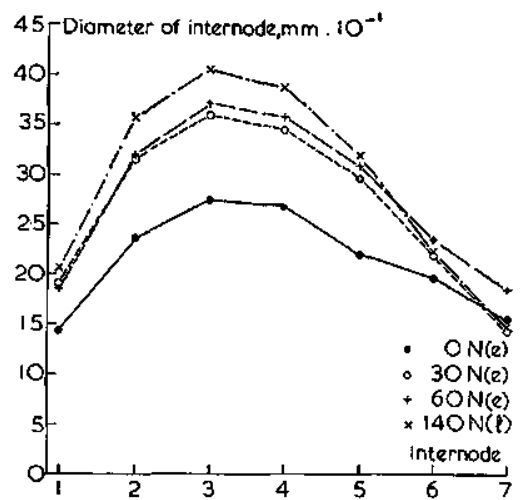

WHEAT

Exp. field 650, 1942

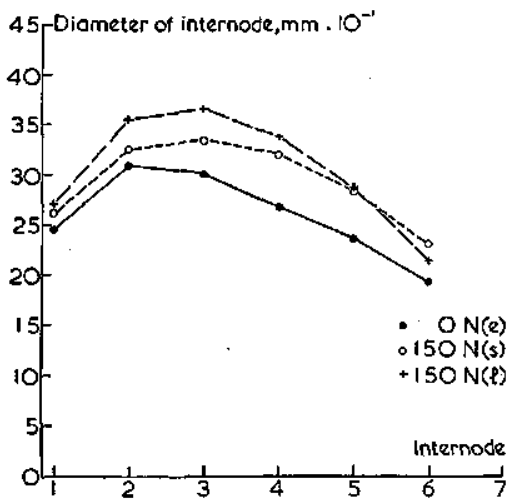

Gen. field 1943

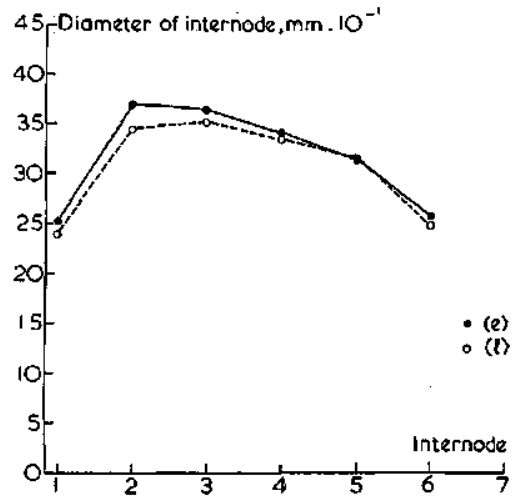

Fig. 7. Diameter of internodes of cereal culms at different nitrogen dressings. $\mathrm{e}=$ erect, $1=$ lodged, $\mathrm{s}=$ supported plants, 1 st $=$ highest internode

3. Diameter of internodes. The culm diameter was measured at the middle of the internodes. The results of a number of measurements are given in Table II (see also Fig. 7). It will be seen that the 3rd or 4th internodes generally have the greatest 


\begin{tabular}{|c|c|c|c|c|c|c|c|c|c|c|c|}
\hline \multirow{13}{*}{ 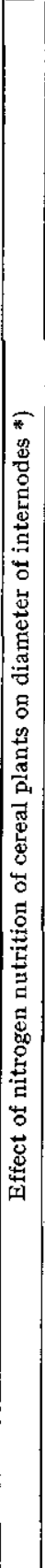 } & \multirow{8}{*}{ 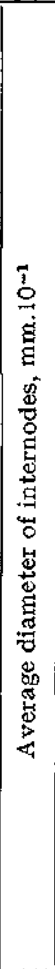 } & $\stackrel{5}{\infty}$ & 111 & 111 & | I | & $|1|$ & 111 & 1111 & 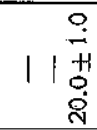 & 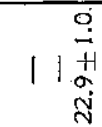 & 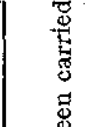 \\
\hline & & 悉 & $\begin{array}{c}0 \\
\stackrel{0}{0} \\
11 \\
1 \\
0 \\
0 \\
0 \\
\end{array}$ & 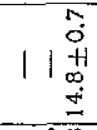 & 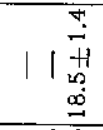 & 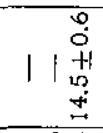 & 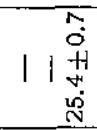 & 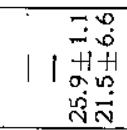 & 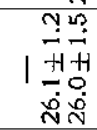 & 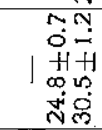 & 吾 \\
\hline & & गี & $\begin{array}{l}00 \\
\dot{0} 0 \\
H+1 \\
N 0 \\
\infty 0 \\
\infty \\
\infty\end{array}$ & 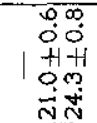 & 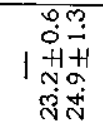 & 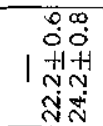 & 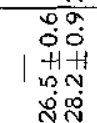 & 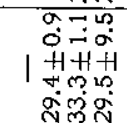 & 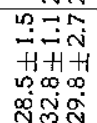 & 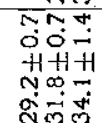 & \\
\hline & & 韋 & 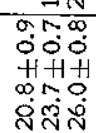 & 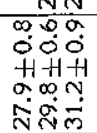 & 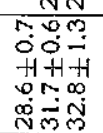 & 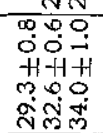 & 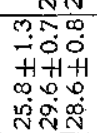 & 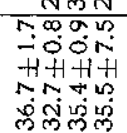 & 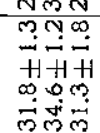 & 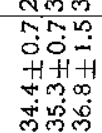 & \\
\hline & & $\underset{7}{7}$ & 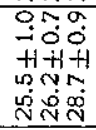 & 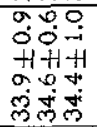 & 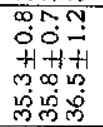 & 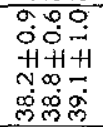 & 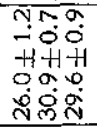 & 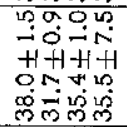 & 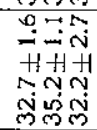 & 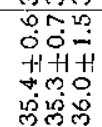 & \\
\hline & & 总 & 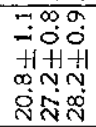 & 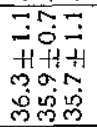 & 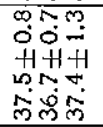 & 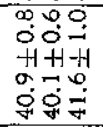 & 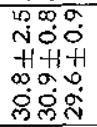 & 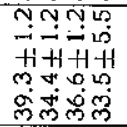 & 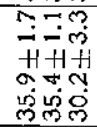 & 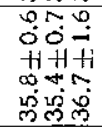 & \\
\hline & & "ెี & 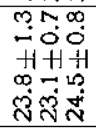 & 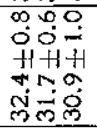 & 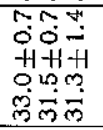 & 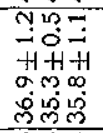 & 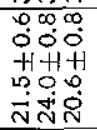 & 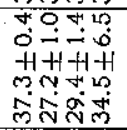 & 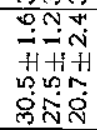 & 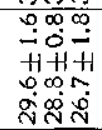 & $\dot{\theta}$ \\
\hline & & 䓪 & 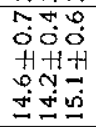 & 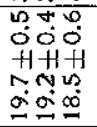 & 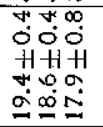 & 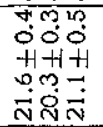 & 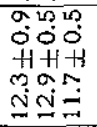 & 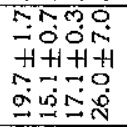 & 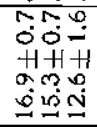 & 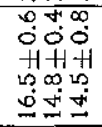 & 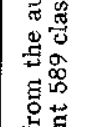 \\
\hline & 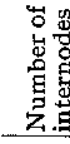 & & DON & WON & DON & son & DOR & $400 N \infty$ & or $\infty$ & $\infty N \infty$ & 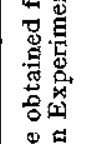 \\
\hline & 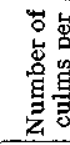 & & ㅊํㅇㅇ & 음옹요 & n̊ㅛㅛ & 윰영 & 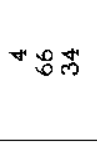 & ms. & ৪ুল̄o & 象芯 & \\
\hline & 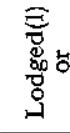 & & 0 & 0 & 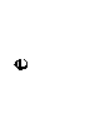 & $\rightarrow$ & (1) & 0 & - & $\rightarrow$ & 次 \\
\hline & $\begin{array}{l}z_{0} \\
b_{0}^{\infty}\end{array}$ & & $\circ$ & ले & 8 & 옥 & 0 & 8 & 8 & $\stackrel{ }{త}$ & \\
\hline & 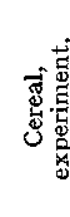 & & 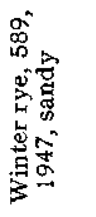 & & & & 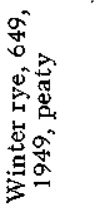 & & & , & \begin{tabular}{l}
5 \\
\multirow{3}{*}{} \\
0 \\
0
\end{tabular} \\
\hline
\end{tabular}


diameter. Plants supplied with inadequate amounts of nitrogen have smaller culm diameters than those with a normal nitrogen supply. With excessive amounts of nitrogen the diameter of the higher internodes may sometimes be increased; the lower internodes, however, have equal or smaller diameters.

When culms with different numbers of measurable internodes in the same samples are compared it appears that as the number of internodes increases the diameter of the lowest ones decreases. This means that increase in internode numbers which may be brought about by excessive nitrogen dressings may reduce the resistance to bending of the culm base.

4. Culmwall thickness. Culm wall thickness like culm diameter is an important property in providing resistance to bending and breaking of cereal culms. The thickness of the culm wall was measured microscopically in the same sections which were used for the measurement of anatomical features. These sections were cut from the middle portions of the second lowest internodes. The results of these measurements are given in Table III. It will be seen that lodged plants which have been supplied excessively with nitrogen may have thinner culm walls than erect plants grown on the same soil at a lower rate of fertiliser dressing. This was the case with the oat plants of Exp. 661, the wheat of Exp. 650 and the wheat of the farmer's field. In the case of the rye plants of Exp. 649 no effect of nitrogen nutrition on culm wall thickness was observed while those of Exp. 589 even had the greatest wall thickness at the highest nitrogen dressing.

In those cases in which culms with different numbers of measurable internodes in the same sample had been investigated, it appeared that those with a greater number of internodes generally had a greater culm wall thickness in the lowest internodes. This means that the decrease in resistance to bending of these plants as a result of decreased culm diameter of the lowest internodes was presumably counterbalanced by an increase in culm wall thickness of these internodes.

5. Thickness of sclerenchymatous ring. The thickness of the sclerenchyma zone of the culm was measured at two quite different places in the transverse section of the second lowest internodes viz. a) where vascular bundles were absent and b) where a small vascular bundle was situated inside the sclerenchyma. In the 
TABLE III

Effect of nitrogen nutrition of cereal plants on culm wall thickness and anatomical characteristics of the second lowest culm internodes

\begin{tabular}{|c|c|c|c|c|c|c|c|c|c|c|}
\hline \multirow[t]{2}{*}{$\begin{array}{l}\text { Cereal, exp., } \\
\text { year and soil }\end{array}$} & \multirow[t]{2}{*}{$\begin{array}{l}\text { Kg N } \\
\text { per ha }\end{array}$} & \multirow{2}{*}{$\begin{array}{l}\text { Lodged } \\
\text { (1) or } \\
\text { erect } \\
\text { (e) }\end{array}$} & \multirow{2}{*}{$\begin{array}{c}\text { Number } \\
\text { of } \\
\text { culms } \\
\text { used }{ }^{* *} \text { ) }\end{array}$} & \multirow{2}{*}{$\begin{array}{c}\text { Number } \\
\text { of } \\
\text { inter- } \\
\text { nodes } \\
\text { per } \\
\text { culm }\end{array}$} & \multirow{2}{*}{$\begin{array}{c}\text { Culm } \\
\text { wall } \\
\text { thick- } \\
\text { ness, } \mu\end{array}$} & \multicolumn{2}{|c|}{$\begin{array}{l}\text { Thickness of } \\
\text { sclerenchy- } \\
\text { matous ring, } \mu\end{array}$} & \multirow{2}{*}{$\left|\begin{array}{c}\text { Lignified } \\
\text { tissue as } \\
\% \text { of } \\
\text { total } \\
\text { area of } \\
\text { scl. ring }\end{array}\right|$} & \multirow{2}{*}{$\begin{array}{c}\text { Thickness } \\
\text { of scleren- } \\
\text { chyma } \\
\text { cell walls, } \\
\mu\end{array}$} & \multirow{2}{*}{$\begin{array}{c}\text { Number } \\
\text { of } \\
\text { vascular } \\
\text { bundles }\end{array}$} \\
\hline & & & & & & $\left|A^{* * *}\right\rangle$ & $B * * *\}$ & & & \\
\hline \multirow{6}{*}{$\begin{array}{l}\text { Winter rye, } \\
649,1949, \\
\text { peat }\end{array}$} & $\overline{0}$. & $\overline{\mathrm{e}}$ & $14-16$ & 6 & $543 \pm 21$ & $85 \pm 14$ & $121 \pm \overline{16}$ & $76 \pm 4$ & $3.5 \pm 0.17$ & $24 \pm 0.8$ \\
\hline & & & $9-10$ & 7 & $593 \pm 41$ & $84 \pm 9$ & $135 \pm 20$ & $68 \pm 4$ & $3.6 \pm 0.25$ & $26 \div 0.8$ \\
\hline & 60 & e & 18 & 6 & $509 \pm 25$ & $81 \pm 4$ & $121 \pm 7$ & $79 \pm 3$ & $3.4 \pm 0.15$ & $27 \pm 0.9$ \\
\hline & 60 & 1 & 8 & 6 & $587 \pm 27$ & $76 \pm 4$ & $115 \pm 3$ & $64 \pm 7$ & $3.5 \pm 0.22$ & $26 \pm 1.6$ \\
\hline & & & 4 & 7 & $635 \pm 61$ & $78 \pm 12$ & $116 \pm 10$ & $55 \pm 3$ & $3.5 \pm 0.17$ & $30 \pm 1.2$ \\
\hline & 120 & 1 & $26-30$ & 6 & $578 \pm 17$ & $82 \div 5$ & $124 \pm 4$ & $65 \pm 3$ & $2.4 \pm 0.10$ & $27 \pm 0.8$ \\
\hline \multirow{3}{*}{$\begin{array}{l}\text { Winter rye, } \\
589,1947, \\
\text { sandy }\end{array}$} & 30 & $\mathrm{e}$ & $59-60$ & - & $570 \pm 17$ & $73 \pm 2$ & - & - & $3.9 \pm 0.11$ & - \\
\hline & 60 & e & 60 & - & $567 \pm 15$ & $71 \pm 2$ & 一 & - & $4.1 \pm 0.11$ & $\rightarrow$ \\
\hline & 140 & 1 & $59-70$ & $一$ & $726 \pm 17$ & $64 \pm 1$ & 一 & - & $2.5 \pm 0.10$ & 一 \\
\hline S.wheat, Gf*), & 80 & e & $21-30$ & 6 & $1009 \pm 27$ & $96 \pm 2$ & $130 \pm 3$ & $82 \pm 3$ & $5.7 \pm 0.11$ & $31 \pm 0.5$ \\
\hline 1943, peaty & 80 & 1 & $27-30$ & 6 & $876=19$ & $71 \pm 2$ & $108 \pm 2$ & $71 \pm 3$ & $4.3 \pm 0.03$ & $30 \pm 0.8$ \\
\hline \multirow{4}{*}{$\begin{array}{l}\text { Oats, } 661, \\
1942, \text { peaty }\end{array}$} & 0 & e & $20-24$ & 5 & $736 \pm 45$ & $71 \pm 4$ & 117 土6 & $84 \pm 2$ & $6.4 \pm 0.20$ & $23 \pm 1.0$ \\
\hline & & & $3-6$ & 6 & $933 \pm 86$ & $92 \pm 16$ & $150 \pm 11$ & $75 \pm 8$ & $7.3 \pm 0.26$ & $22 \pm 1.6$ \\
\hline & 160 & 1 & $25-29$ & 5 & $566 \pm 16$ & $70 \pm 2$ & $110 \pm 2$ & $84 \pm 2$ & $5.3 \pm 0.15$ & $22 \pm 0.4$ \\
\hline & & & $27-33$ & 6 & $672 \pm 23$ & $96 \pm 4$ & $134 \pm 3$ & $69 \pm 2$ & $6.3 \pm 0.14$ & $22 \pm 0.5$ \\
\hline \multirow{4}{*}{$\begin{array}{l}\text { S. wheat, } \\
650,1942, \\
\text { peaty }\end{array}$} & 0 & e & $25-28$ & 5 & $.03 \pm 22$ & $84 \pm 3$ & $116 \pm 3$ & $99 \pm 0$ & $5.9 \pm 0.10$ & $25 \pm 0.2$ \\
\hline & & & $9-11$ & 6 & $316=45$ & $96 \pm 6$ & $140 \pm 6$ & $88 \pm 5$ & $5.7 \pm 0.18$ & $25 \pm 1.0$ \\
\hline & 150 & 1 & $22--24$ & 5 & $649+24$ & $81 \pm 3$ & $125 \pm=4$ & $93 \pm 2$ & $4.6 \pm 0.15$ & $26 \pm 0.5$ \\
\hline & & & $44-48$ & 6 & $724 \pm 20$ & $90 \pm 3$ & $130 \pm 3$ & $81 \pm 2$ & $=34-0.13$ & $26 \pm 0.3$ \\
\hline
\end{tabular}

*) $\mathrm{Gf}=$ general field.

**) Culms collected: Exp. 649 shortly after blooming, Exp. 589 two weeks, Gf and Exp, 661 a few days and Exp. 650 four weeks before harvesting.

***) A : no vascular bundle, B: vascular bundle inside sclerenchymatous ring.

latter case the sclerenchyma zone always is considerably thicker.

As may be seen from Table III the thickness of the sclerenchymatous ring was unaffected by the nitrogen nutrition in the case of the rye of Exp. 649 and the wheat of Exp. 650. In the oats of Exp. 661 nitrogen manuring tended to reduce the development of the sclerenchyma. In the rye of Exp. 589 and the wheat of the general field the thickness of the sclerenchyma zone of the lodged plants was considerably reduced. Since a strong sclerenchymatous ring is of much importance for the standing ability of the culm, a reduction

Plant and Soil V 
of this tissue undoubtedly enhances the liability of the plant to lodging.

6. Thickness of sclerenchyma cell walls. Of all the anatomical characters studied thickness of sclerenchyma cell walls was affected most consistently by nitrogen manuring. In the lodged rye plants of Exp. 589 and Exp. 649 the greatest reduction in lignification was found (Table III and Plate II A and B).

7. Thickness of lignified parenchyma cell walls. In addition to thickness of sclerenchyma cell walls, lignification of the exterior layers of inner parenchyma was found to be clearly reduced in the case of ample nitrogen supply. Although no measurements of this character have been carried out, the microphotographs clearly show the differences in wall thickness of these parenchyma cells (Plate II A and B).

8. Area of lignified tissue in sclerenchymatous ring. As was described in section 3, bands of green parenchyma are embedded in the sclerenchyma. The extension of these bands appeared to be affected by the nitrogen nutrition of the plants. Lodged plants, supplied excessively with nitrogen often have larger parenchyma bands than those supplied poorly with nitrogen. This may be concluded from Table III, column 9, where a large area of lignified tissue corresponds with a poor development of the parenchyma bands.

9. Lignin content of basal culm internodes. The results of a number of lignin determinations in the second lowest internodes of cereal culms are recorded in Table IV. It will be seen that in general the lodged plants have a lower lignin content in their basal culm internodes than the non-lodged plants. The differences are less pronounced, however, than in the case of thickness of sclerenchyma cell walls.

10. Number of vascular bundles. According to Mol$\mathrm{d}$ e $\mathrm{n} \mathrm{h}$ a w e ${ }^{25}$ ) wheat varieties resistant to lodging have a greater number of vascular bundles than those with a great tendency to lodging. This statement was denied by $\mathrm{Caffrey}$ and $\mathrm{Carrol1}{ }^{8}$ ) but $\mathrm{Hamil}$ t o $\mathrm{n}^{19}$ ) found a larger number of vascular bundles in a lodging-resistant oat variety than in a non resistant one.

In the present study it was observed that oat culms have a smaller number of vascular bundles than rye and wheat culms. The latter apparently possess the greatest number. No effect of nitrogen nutri- 
TABLE IV

Effect of nitrogen nutrition of cereal plants on lignin content of the lower culm (second lowest internodes)

\begin{tabular}{|c|c|c|c|c|}
\hline Cereal *) & $\begin{array}{l}\text { Experiment, } \\
\text { year and soil }\end{array}$ & $\begin{array}{l}\mathrm{Kg} \mathrm{N} \\
\text { per ha }\end{array}$ & $\begin{array}{l}\text { Lodged (1) } \\
\text { or erect(e) }\end{array}$ & $\begin{array}{l}\text { Lignin, \% of } \\
\text { dry matter }\end{array}$ \\
\hline Winter rye & $\begin{array}{l}589 \\
1947 \\
\text { sandy }\end{array}$ & $\begin{array}{r}0 \\
30 \\
60 \\
140\end{array}$ & $\begin{array}{l}\mathrm{e} \\
\mathrm{e} \\
\mathrm{e} \\
1\end{array}$ & $\begin{array}{l}19.3 \pm 0,07 \\
19.3 \pm 0.28 \\
19.5 \pm 0.08 \\
16.0 \pm 0.12\end{array}$ \\
\hline Winter rye & $\begin{array}{r}649 \\
1949 \\
\text { peaty }\end{array}$ & $\begin{array}{r}0 \\
60 \\
60 \\
120\end{array}$ & $\begin{array}{l}e \\
\mathrm{e} \\
1 \\
1\end{array}$ & $\begin{array}{l}15.1 \pm 0.26 \\
17.7 \pm 0.04 \\
16.9 \pm 0.13 \\
16.9 \pm 0.09\end{array}$ \\
\hline Summer wheat & $\begin{array}{l}\text { General field } \\
1943, \text { peaty }\end{array}$ & $\begin{array}{l}80 \\
80\end{array}$ & $\begin{array}{l}\text { e } \\
1\end{array}$ & $\begin{array}{l}20.3 \pm 0.35 \\
19.1 \pm 0.24 * *) \\
18.5 \pm 0.24 \\
\left.17.4 \pm 0.37^{* *}\right)\end{array}$ \\
\hline Summer wheat & $\begin{array}{l}650 \\
1942 \\
\text { peaty }\end{array}$ & $\begin{array}{r}0 \\
150\end{array}$ & $\begin{array}{l}e \\
1\end{array}$ & $\begin{array}{l}19.7 \pm 0.03 \\
15.7 \pm 0.17 * * *) \\
17.6 \pm 0.12 \\
14.3 \pm 0.43 * * *)\end{array}$ \\
\hline Oats & $\begin{array}{l}661 \\
1942 \\
\text { peaty }\end{array}$ & $\begin{array}{r}0 \\
160\end{array}$ & e & $\begin{array}{l}21.3 \pm 0.10 \\
18.6 \pm 0.11 * *) \\
20.5 \pm 0.04 \\
18.2 \pm 0.21 * *)\end{array}$ \\
\hline
\end{tabular}

*) Culms collected: Exp. 589 two weeks before harvesting, Exp. 649 shortly after flowering, Gf and Exp. 661 a few days and Exp. 650 four weeks before harvesting.

**) Sample pre-treated with ethanol-benzene mixture, followed by an extraction with water at $60^{\circ} \mathrm{C}$.

***) Third lowest internodes.

tion was found as may be seen in Table III column 11. The degree of lignification of the vascular bundles, however, is clearly affected by the nitrogen nutrition. In agreement with the lignification of the sclerenchymatous ring which is reduced by an ample nitrogen supply, it was found that the layer of lignified cells surrounding the vascular bundle was clearly more lignified when the nitrogen nutrition of the plants had been inadequate.

11. Weight per cm of culm length in lower internodes. Weight per unit length of culm base was found by A t kin ${ }^{2}$ ) to be positively correlated with breaking strength of the straw. It is obvious, however; that ahigh value for this 
character is of much importance in the standing ability of the plant only if the dry matter available is distributed in such a way that a high resistance to bending and breaking has been attained.

The weight of an internode per unit of length depends on a) $\mathrm{cnlm}$ diameter, b) thickness of culm wall and c) chemical composition of the culm wall.

TABLE V

\begin{tabular}{|c|c|c|c|c|c|c|c|}
\hline \multicolumn{6}{|c|}{ Effect of nitrogen nutrition of cereal plants on weight per cm of culm length (second } \\
1owest internodes)
\end{tabular}

*) $100 \mathrm{~kg} \mathrm{~K} \mathrm{~K}_{2} \mathrm{O}$ per ha.

**) $300 \mathrm{~kg} \mathrm{~K}, \mathrm{O}$ per ha.

†) $\mathrm{s}=$ supported.

†) Culms with 5, 6,7 and 8 internodes respectively.

As will be seen from the results in Table $V$ the highest values for this property have generally been found in plants dressed with a low or moderate amount of fertiliser nitrogen. With an ample nitrogen supply considerably lower weights have been found.

12. Root syste $m$. Preliminary observations on the root system of lodged and erect plants showed that in general the latter had more 

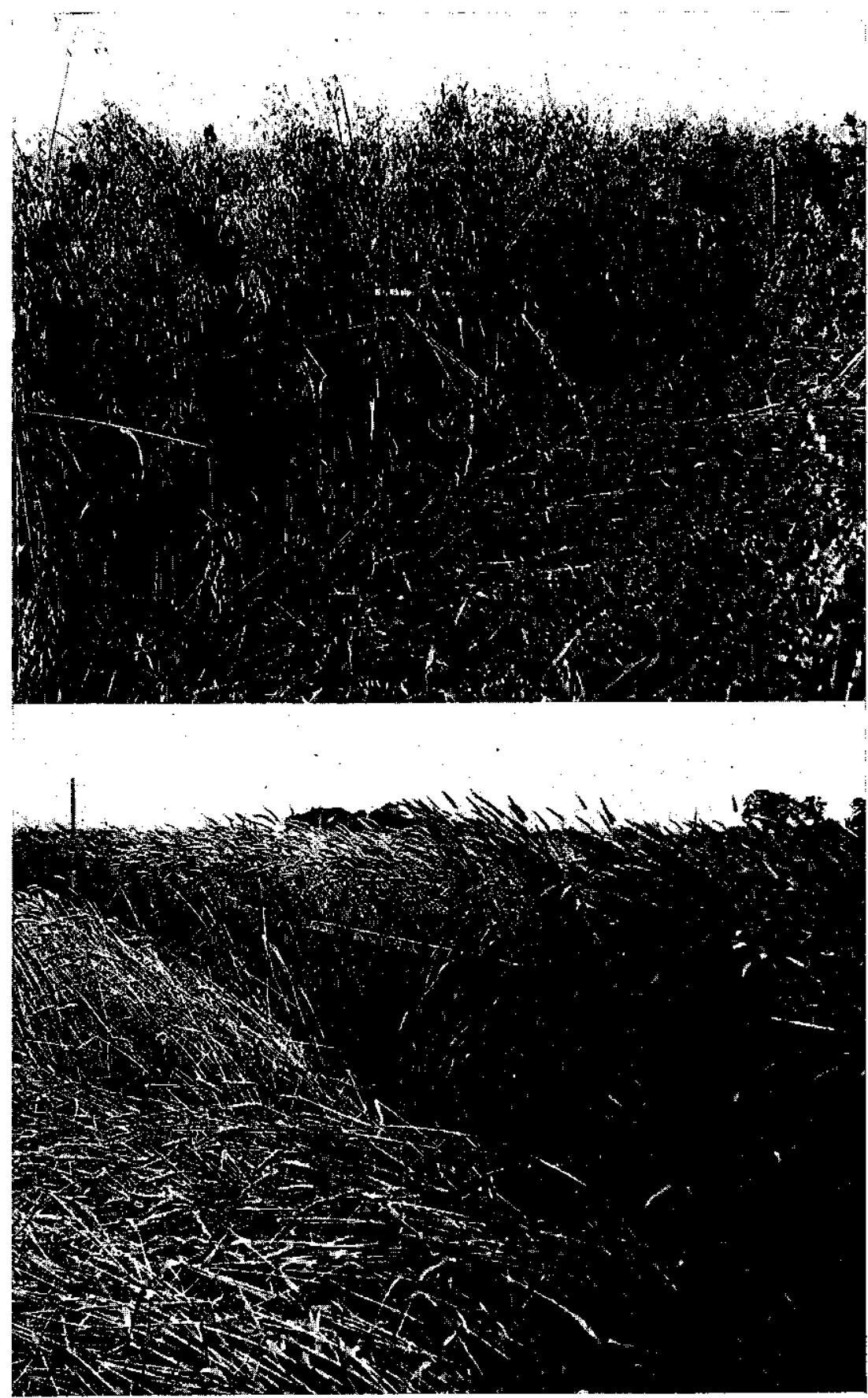

Plate I. Lodged oat and wheat plants amply dressed with nitrogen. Part of the plots supported by ropes to prevent lodging. 
A

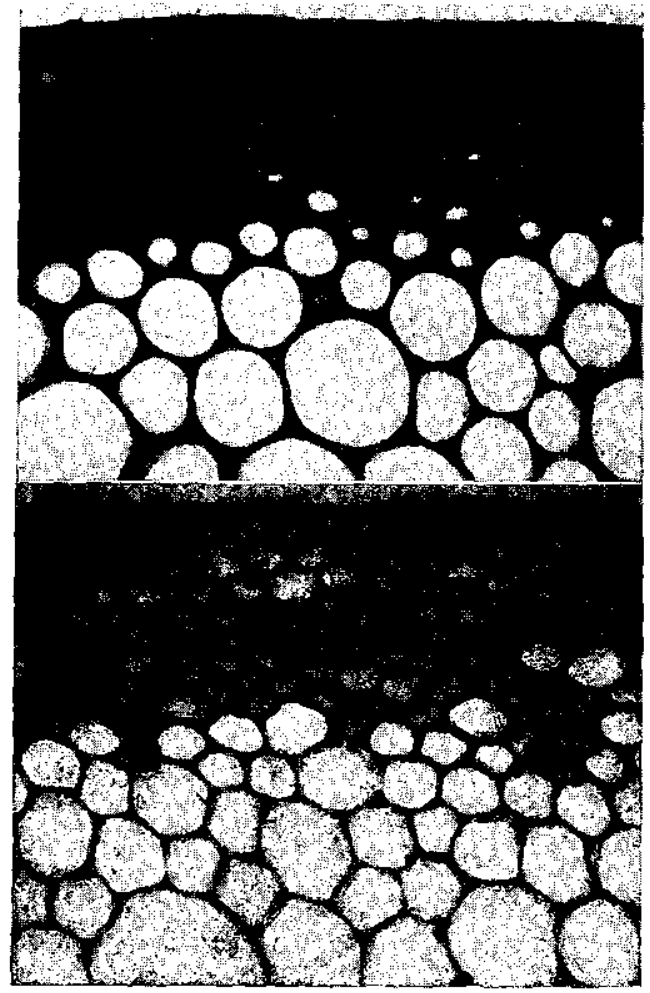

Plate 11. Sclerenchymatous ring and lignified parenchyma of basal culm internodes of rye. A: erect plants, dressed with $30 \mathrm{~kg} \mathrm{~N}$ per ha; B : lodged plants, dressed with $140 \mathrm{~kg} \mathrm{~N}$ per ha.

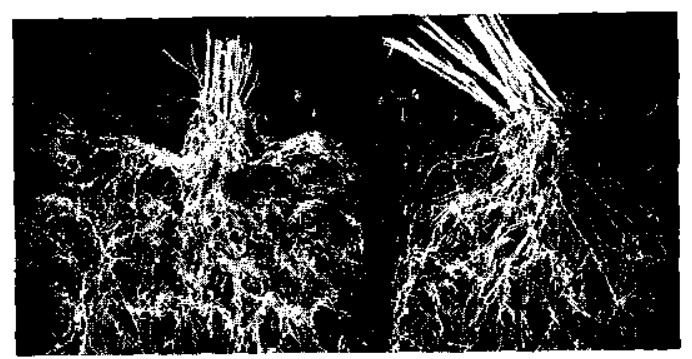

Plate III. Root system of oat plants on pin boards after being washed free from soil. Left: erect plants, dressed moderately with nitrogen: right: lodged plants, supplied excessively with nitrogen. 
sturdy roots. This was confirmed by a number of experiments in 1953 in which root systems of lodged and erect plants have been collected and studied. The root samples were taken according to the method described on page 251 a few weeks before ripening of the crop. At that time the coronal roots of the non-lodged plants which had been supplied with a moderate amount of nitrogen were more vigorous than those of the lodged plants which had been supplied amply with nitrogen (see Plate III and IV and Table VI). They were

TABLE VI

\begin{tabular}{|l|c|c|c|}
\hline \multicolumn{3}{|c|}{ Effect of nitrogen nutrition (lodging) on weight of roots of cereal plants } \\
\hline Field and cereal & $\begin{array}{c}\text { Nitrogen } \\
\text { supply }\end{array}$ & $\begin{array}{c}\text { Lodged(1) } \\
\text { or erect(e) }\end{array}$ & $\begin{array}{c}\text { Yield of roots, g } \\
\text { (to a depth of } \\
20 \mathrm{~cm} \text { ) }\end{array}$ \\
\hline 2. Summer wheat & $\begin{array}{l}\text { moderate } \\
\text { excessive }\end{array}$ & $\mathrm{e}$ & 2.94 \\
3. Summer wheat & moderate & $\mathrm{e}$ & 1.18 \\
& excessive & 1 & 1.71 \\
6. Oats & moderate & $\mathrm{e}$ & 1.04 \\
7. Oats & excessive & 1 & 2.46 \\
& low & $\mathrm{e}$ & 1.57 \\
8. Oats & excessive & $\mathrm{e}$ & 2.53 \\
& moderate & $\mathrm{e}$ & 1.99 \\
\hline
\end{tabular}

slightly thicker, were much less flexible, had many more branch roots and had a white colour as contrasted with the yellow-brown colour of the roots of lodged plants. Furthermore there existed a pronounced difference in lignification (TableVII). The coronal roots of the lodged oat plants were practically free from lignified cells beneath the epidermis as contrasted with those of the non-lodged plants which had a zone of lignified cells (Plate VA and B). Degree of lignification of the stele was also less pronounced. Lignin as per cent of dry matter was found to be slightly higher in roots of lodged plants. The latter need not be contradictory to the anatomical picture if it is assumed that in the erect plants, in addition to lignin, other C-compounds in even greater quantities have been used to strengthen the tissues. 
TABLE VII

\begin{tabular}{|c|c|c|c|c|c|c|c|c|c|c|}
\hline \multicolumn{11}{|c|}{$\begin{array}{c}\text { of nitrogen uutrition on root characters of oat and wheat plants (coronal roots at } 1 \mathrm{~cm} \text { from } \\
\text { culm base). }\end{array}$} \\
\hline \multirow[b]{2}{*}{$\begin{array}{l}\text { Cereal } \\
\text { and } \\
\text { nitrogen } \\
\text { supply }\end{array}$} & \multirow[b]{2}{*}{$\begin{array}{l}\text { Lodged } \\
\text { (I) or } \\
\text { erect(e) }\end{array}$} & \multirow[b]{2}{*}{$\begin{array}{c}\text { Number } \\
\text { of roots } \\
\text { used }\end{array}$} & \multirow[b]{2}{*}{$\begin{array}{c}\text { Dia- } \\
\text { meter, } \\
\mu\end{array}$} & \multirow[b]{2}{*}{$\begin{array}{c}\text { Dia- } \\
\text { meter } \\
\text { of } \\
\text { stele, } \\
\mu\end{array}$} & \multicolumn{3}{|c|}{$\begin{array}{l}\text { Lignified layer beneath } \\
\text { hypodermis }\end{array}$} & \multirow{2}{*}{\begin{tabular}{|c} 
Wall \\
thick- \\
ness of \\
lignified \\
cells \\
in stele \\
$\mu$
\end{tabular}} & \multirow{2}{*}{$\begin{array}{c}\text { Thick- } \\
\text { ness of } \\
\text { inner } \\
\text { cell wall } \\
\text { of endo- } \\
\text { dermis, } \\
\mu\end{array}$} & \multirow{2}{*}{\begin{tabular}{|c} 
Ratio, \\
thickness \\
inner cell \\
wall to \\
width of \\
endo- \\
dermis
\end{tabular}} \\
\hline & & & & & $\begin{array}{c}\text { Number } \\
\text { of } \\
\text { cell } \\
\text { layers }\end{array}$ & \begin{tabular}{|c|} 
Thick- \\
ness \\
of \\
layer, \\
$\mu$
\end{tabular} & $\begin{array}{c}\text { Thick- } \\
\text { ness of } \\
\text { lignified } \\
\text { cell wall, } \\
\mu\end{array}$ & & & \\
\hline \multirow{3}{*}{$\begin{array}{l}\text { Oats } \\
\text { Moderate } \\
\text { Excessive }\end{array}$} & & & & & & & & & & \\
\hline & e & 48 & $906 \pm 21$ & $335 \pm 9$ & $2.0 \pm 0.17$ & $47 \pm 3.5$ & $3.5 \pm 0.13$ & $3.0 \pm 0.10$ & $6.0 \pm 0.22$ & $0.36 \pm 0.14$ \\
\hline & 1 & 46 & $862 \pm 28$ & $369 \pm 10$ & $0.3 \pm 0.13$ & $7 \pm 0.3$ & $2.9 \pm 0.51$ & $2.2 \pm 0.07$ & $3.4 \pm 0.25$ & $0.17 \pm 0.13$ \\
\hline \multicolumn{11}{|l|}{ S. wheat } \\
\hline Moderate & e & 16 & $806 \pm 22$ & $341 \pm 10$ & $2.9 \pm 0.37$ & $70 \pm 8.2$ & $3.7 \pm 0.45$ & $2.4 \pm 0.08$ & $5.6 \pm 0.34$ & $0.33 \pm 0.03$ \\
\hline Excessive & 1 & 16 & $789 \pm 39$ & $323 \pm 16$ & $2.1 \pm 0.31$ & $45 \div 6.4$ & $1.8 \pm 0.27$ & $1.9 \pm 0.08$ & $4.0 \pm 0.23$ & $0.21 \pm 0.02$ \\
\hline S. wheat & & & & & & & & & & \\
\hline Moderate & $\mathrm{e}$ & 14 & $894 \pm 47$ & $401 \pm 22$ & $3.4 \pm 0.18$ & $77 \pm 3.8$ & $2.9 \pm 0.25$ & $2.0 \pm 0.15$ & $4.7 \pm 0.35$ & $0.25 \pm 0.03$ \\
\hline Excessive & 1 & 14 & $888 \pm 25$ & $366 \pm 11$ & $2.6 \pm 0.19$ & $60 \pm 3.8$ & $2.2 \pm 0.15$ & $1.8 \pm 0.11$ & $3.9 \pm 0.21$ & $0.19 \pm 0.02$ \\
\hline
\end{tabular}

A very marked contrast existed in the degree of thickening of the inner cell wall of the endodermis (Plate VC and D).

The loss of most branch roots and also the discolouration indicate that the roots of the lodged plants had been more liable to microbial attack than those of the non-lodged plants which were quite intact. It is probable that the large differences in weight of roots between lodged and erect plants (cf Table VI) are partly due to the more severe attack on the former roots by micro-organisms during the period between flowering and ripening of the crop. That during this period in cereals a decrease in root weight may occur can be seen from the data of $\mathrm{Sehul} \mathrm{ze}^{33}$ ).

The results of the above-mentioned experiments have shown that weakness of the basal parts of cereal plants in different cases may depend on a poor development of different plant characters. In one case a small diameter of the basal culm internodes will be the limiting factor, in a second a reduced culm wall thickness, a poor lignification of the culm tissues, or a weak root system, while in a third a combination of these factors occurs.

Liability to lodging, however, does not merely depend on weakness of lower culm or root system but on also lack of proportionality between sturdiness of the basal parts of the plant and weight of the 


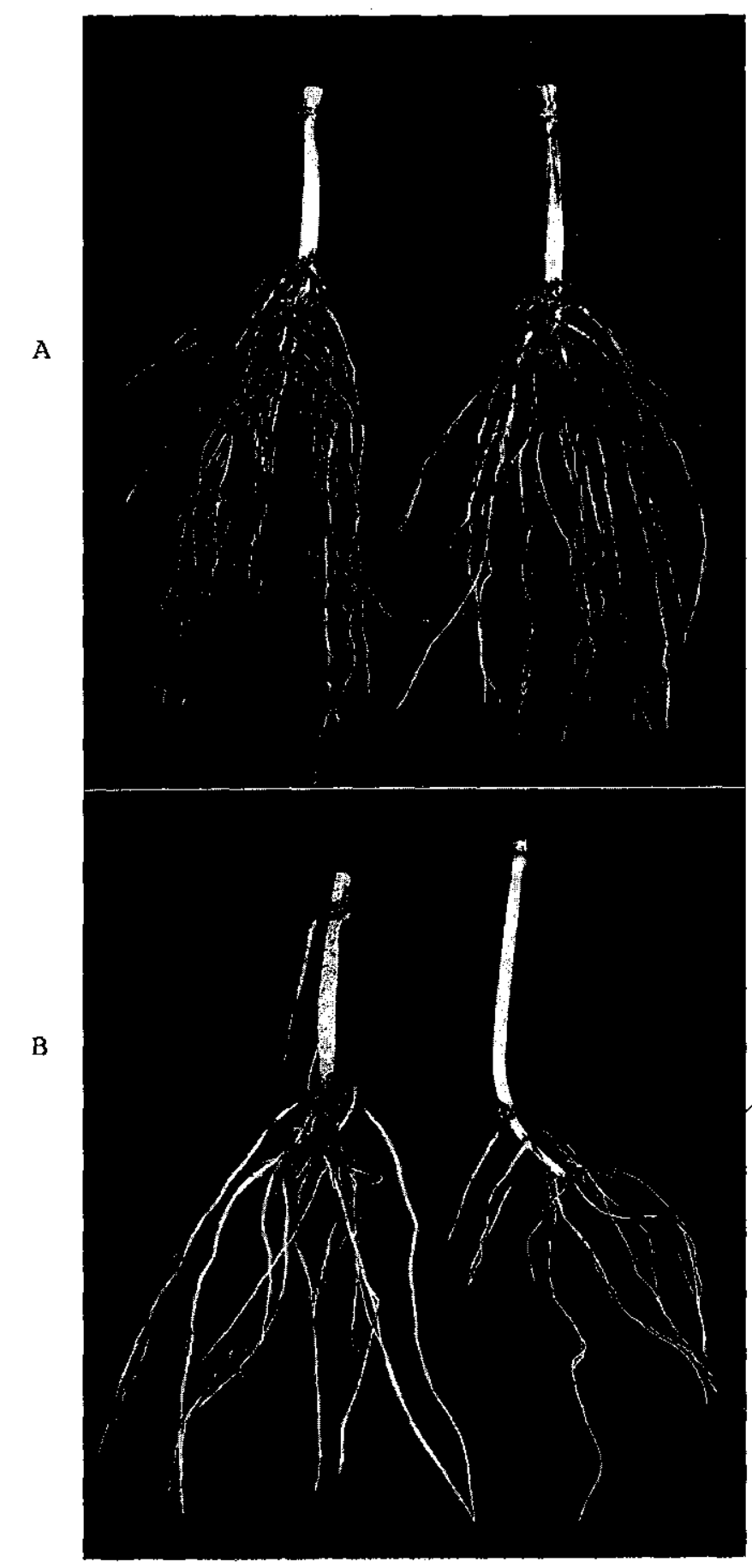

Plate IV. Culm bases and root systems of oat plants. A : erect plants, supplied moderately with nitrogen. B: lodged piants, supplied excessively with nitrogen. 
A

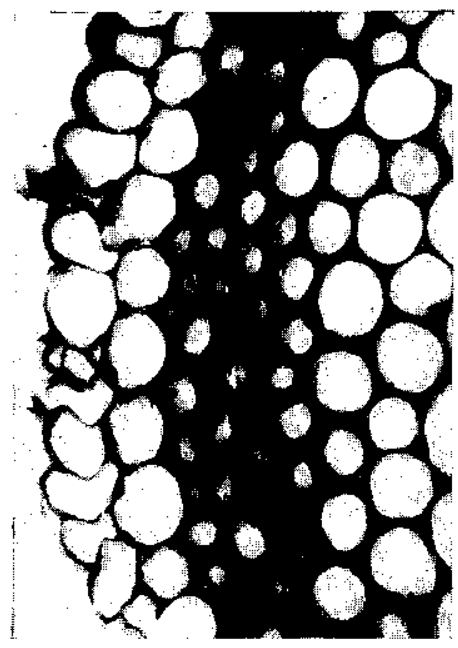

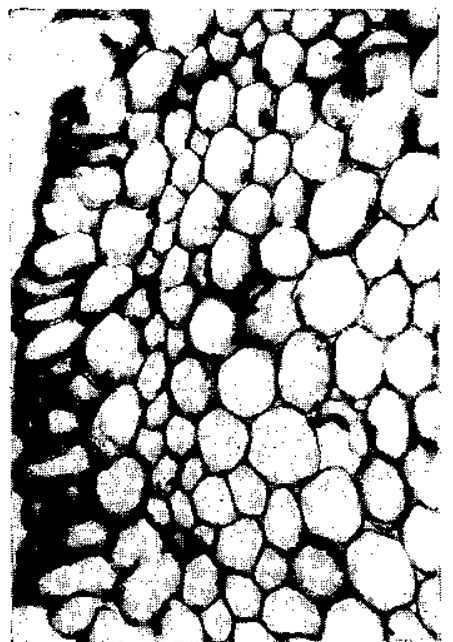

B
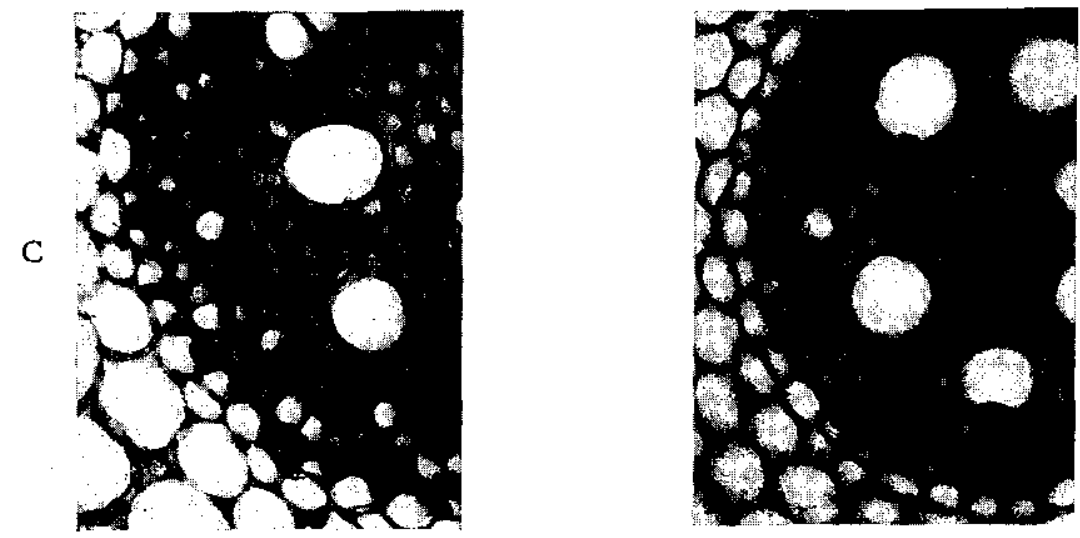

Plate V. Transverse sections of coronal roots of oats. A and B : epidermis with part of cortex. C and D; stele with endodermis. $A$ and $C$ : moderate nitrogen, erect plants. B and D: excessive nitrogen, lodged plants. The roots of the erect plants possess three lignified cell layers beneath the hypodermis which are absent in the roots of the lodged plants. Furthermore the inner cell walls of the endodermis of the former plants and the walls of the lignifted cells of the stele are more thickened than is the case in roots of lodged plants. 
upper parts. A crop with relatively strong lower culms and roots may have a high liability to lodging when the plants are longstrawed and have heavily developed upper culm internodes, leaves and ears. On the other hand a plant with relatively weak basal culms and roots may have a low tendency to lodging because of poor development of upper parts and of shortness of straw.

\section{c. The cause of the nitrogen effect}

The influence of nitrogen nutrition on various plant characters, as described above, may be attributed to a direct physiological

Exp. tield 612,1941
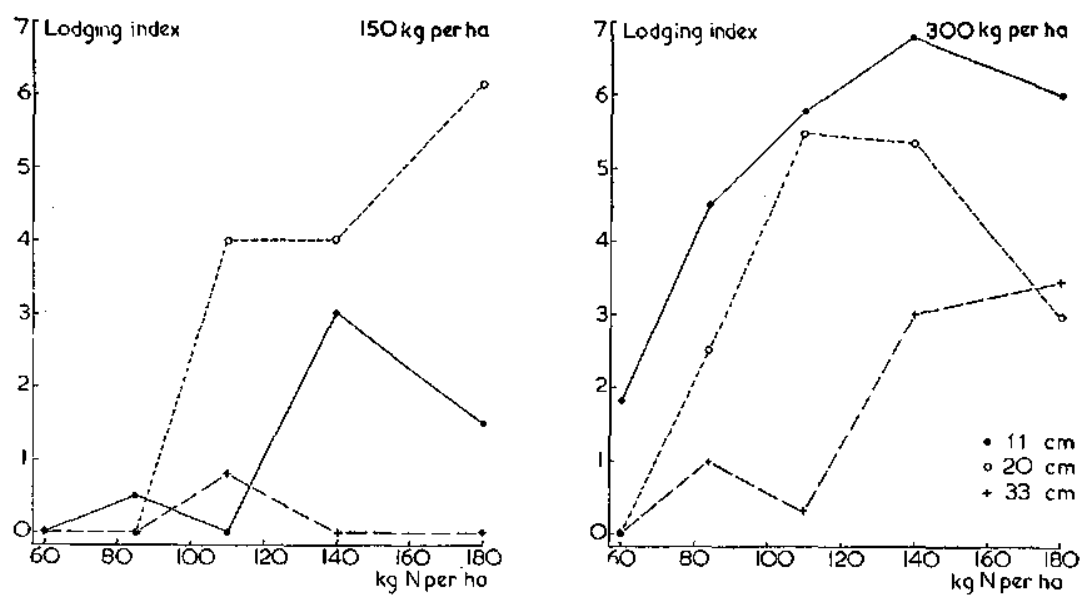

Fig. 8. Effect of rate of seeding (150 and $300 \mathrm{~kg}$ per ha), spacirg (11, 20 and $33 \mathrm{~cm}$ ) and nitrogen nutrition on lodging of winter rye. Lodging indices determined 46 days before harvesting.

effect of nitrogen or to an indirect effect resulting from increased shading of the lower internodes of the culms. An improved nitrogen nutrition favours the stooling of the plants as well as leaf development. Both factors considerably increase the density of the crop. In order to study the direct and indirect effects separately the following experiments have been carried out:

1. Rye and wheat were sown on experimental fields at different rates and at different spacings. By varying the amount of applied. 
fertiliser nitrogen, it was possible to study the effect of nitrogen at varying degrees of density of the crop.

2. Oats were sown in Mitscherlich pots and supplied with different amounts of nitrogen. A number of pots were exposed to full sunshine in a greenhouse whereas the others were placed in part of the greenhouse where direct sunshine was excluded by using curtains of white paper. Wire frames were used for supporting the leaves in such a way that the exposure to light of the lower internodes was not affected by variations in leaf development resulting from differences in nitrogen nutrition.

1. Field experiments. Winter rye and summer wheat were sown at the rate of 75,150 and $300 \mathrm{~kg}$ per ha at 11,20 and $33 \mathrm{~cm}$ spacing. Nitrogen was applied at the rate of 60,85, 110,140 and 180 $\mathrm{kg} \mathrm{N}$ per ha in 1941 and $0,40,80,120$ and $160 \mathrm{~kg} \mathrm{~N}$ per ha in 1942. In both cases ammonium nitrate limestone has been used as the nitrogenous fertiliser.

The winter rye of Exp. 612 (1941) lodged shortly after flowering. Lodging indices have been plotted in Fig. 8 . The effect of density of the crop on lodging appeared to be of more importance than that of nitrogen supply. This may be concluded from the fact that a dressing of $180 \mathrm{~kg} \mathrm{~N}$ per ha gave no lodging when the rye had been sown at the rate of $150 \mathrm{~kg}$ per ha and at $33 \mathrm{~cm}$ spacing, whereas severe lodging occurred at much lower dressings of nitrogen when the stand of the crop was more dense. Similar results have been obtained on Plot 659 with winter rye and on Plot 658 with summer wheat in 1942 (see Fig. 9). On Exp. plot 612 the highest grain yield was obtained at spacings of 20 and $33 \mathrm{~cm}$. At $11 \mathrm{~cm}$ grain production was considerably reduced. The rate of seeding had little effect on yield in this experiment. On Exp. plot 658 a spacing of $11 \mathrm{~cm}$ gave a marked drop in grain yield when the wheat was sown at $300 \mathrm{~kg}$ per ha and when the nitrogen supply was higher than $80 \mathrm{~kg}$ per ha. On Exp. plot 659 a spacing of $11 \mathrm{~cm}$ gave markedly higher grain yields than one of $33 \mathrm{~cm}$. At $20 \mathrm{~cm}$ the grain yields were similar to those at $11 \mathrm{~cm}$. A rate of seeding of $75 \mathrm{~kg}$ per ha was inadequate for obtaining an optimal yield on both latter experimental plots. On plot 659, $300 \mathrm{~kg}$ gave even higher grain yields than $150 \mathrm{~kg}$ notwithstanding the fact that lodging was much more severe at the former rate of seeding (cf Fig. 9). This demonstrates that in this case lodging hardly reduced grain production. 
The results of a number of measurements of length and thickness of internodes are plotted in Fig. 10. The effect of excessive nitrogen on length of lower internodes was particularly clear in the wheat plants of Experiment 658 at a rate of seeding of $300 \mathrm{~kg}$ per ha. That

\section{WHEAT \\ Exp.field 658,1942}
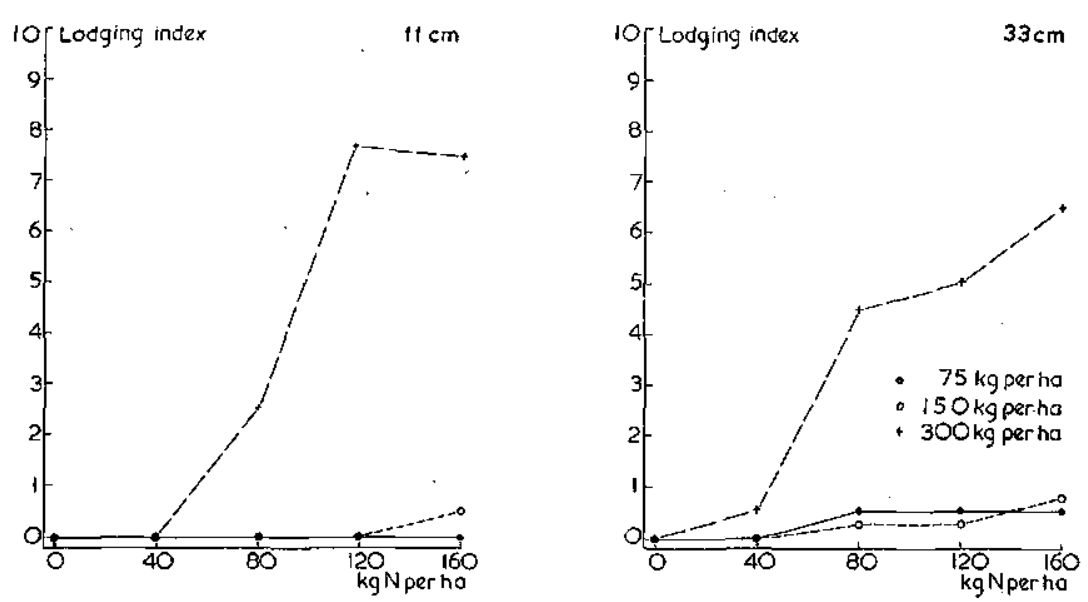

RYE

Exp. field 659,1942
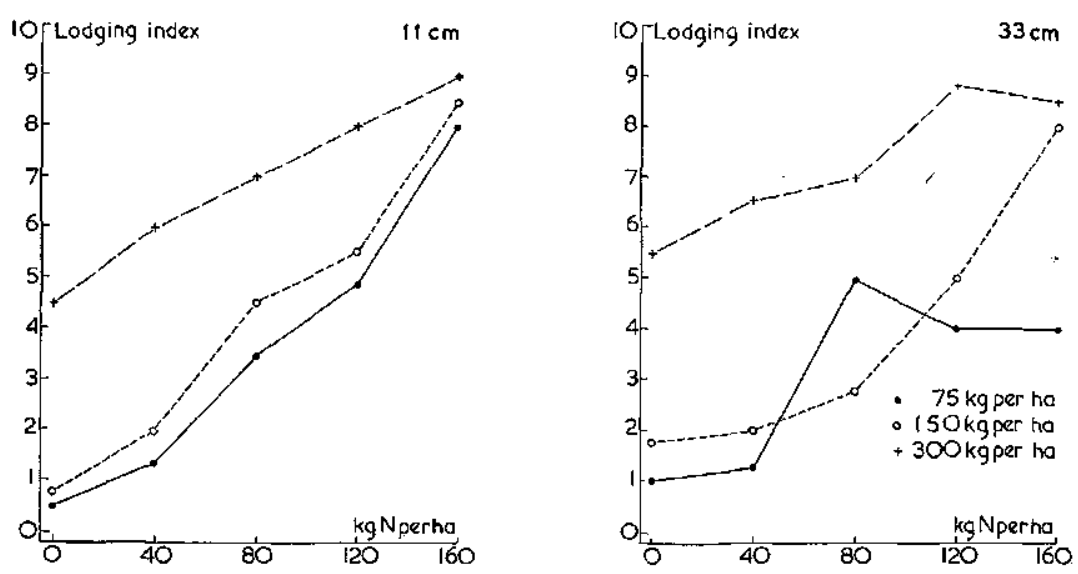

Fig. 9. Effect of rate of seeding (75, 150 and $300 \mathrm{~kg}$ per ha), spacing (11 and $33 \mathrm{~cm}$ ) and nitrogen nutrition on lodging of summer wheat and winter rye. Lodging indices determined 7 days before harvesting. 


\section{RYE}
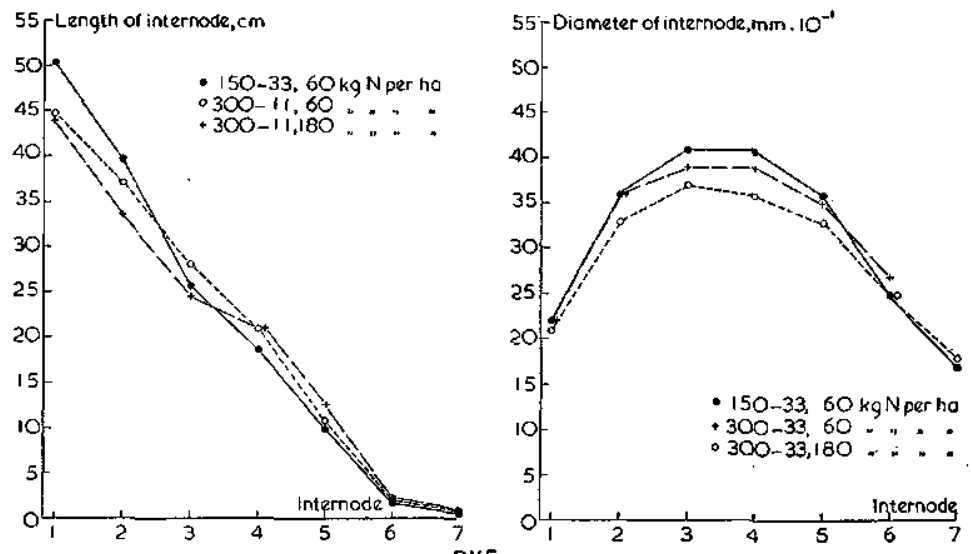

RYE. Field 659,1942

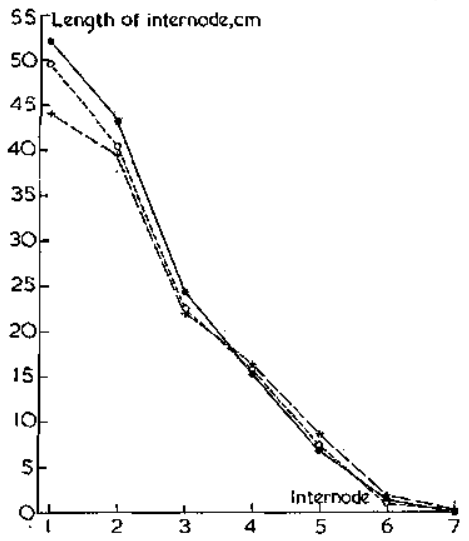

55 -Diometer of internodk, $\mathrm{mm}, 1 \mathrm{O}^{-1}$

WHEAT

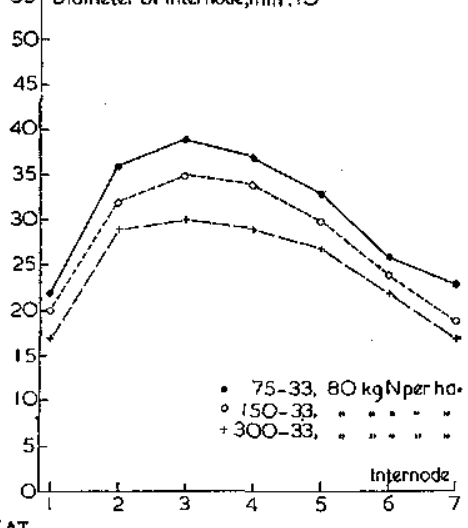

Exp. field 658,1942
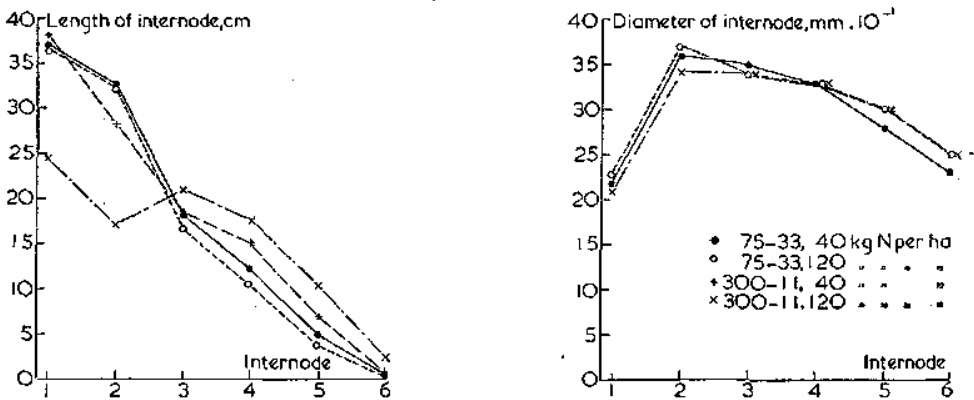

Fig. 10. Effect of rate of seeding (75, 150 and $300 \mathrm{~kg}$ per ha), spacing (11 and $33 \mathrm{~cm})$ and nitrogen nutrition on length and diameter of culm internodes of winter rye and summer wheat. 1 st $=$ highes.t internode. For lodging indices see Tables VIII and IX. 
this effect was indirect, resulting from shading of the lower internodes through increased stooling and leaf formation, may be concluded from the fact that plants sown at a rate of seeding of 75 or $150 \mathrm{~kg}$ per ha and at a spacing of $33 \mathrm{~cm}$ did not possess longer lower internodes when dressed with excessive nitrogen. Apparently in the latter case the increased leaf formation was inadequate to prevent the exposure to direct sunlight of the lower internodes.

Similarly plants with equal nitrogen dressings possessed considerably longer lower internodes when the density of the crop was greater because of a higher rate of seeding or a narrower spacing.

In the case of the rye plants of Experiments 612 and 659 density of crop and nitrogen nutrition exerted only a slight effect on the length of the lower internodes. The number of internodes tended to increase with increased density of the crop. As a result of this, higher values for the lower internodes may be found in the more densely sown crops of the latter experiments when average values for all culms per sample are calculated (cf footnote on p. 263).

Culm diameter of the lower internodes of rye plants was considerably reduced by an increased rate of seeding on Exp. plot 659 . This may have been the main cause of the differences in lodging between plots of different density. In the case of Exp. 612 (rye) and Exp. 658 (wheat), however, reduced culm diameter cannot have been responsible for the increased lodging of crops with a higher density or with an increased nitrogen supply as practically no effect of these conditions on culm diameter was observed (see Fig. 10).

Weight per unit of culm length was considerably reduced by increased density of the crop in the case of Exp. 658 (wheat) and of Exp. 659 (rye) but not on Exp. 612 (Table VIII). In the wheat plants it was apparently due partly to the thicker culm wall of the les's densely sown plants. A slight effect of nitrogen nutrition on culm wall thickness was noted in the rye of Exp. 612 as well as in the wheat of Exp. 658 (Table IX).

No clear relationship between density and nitrogen nutrition of the crop and extension of sclerenchymatous tissue was observed in the rye plants of Exp. 612. In the case of the wheat of Exp. 658 the lodged plants of the densely sown crop (300-11) treated excessively with nitrogen had a thinner sclerenchyma ring than plants sown under less dense conditions (75-33). The area of lignified tissue of 
TABLE VIII

\begin{tabular}{|c|c|c|c|c|c|c|c|c|}
\hline \multicolumn{9}{|c|}{$\begin{array}{l}\text { Effect of nitrogen nutrition, rate of seeding and spacing of cereal plants on weight } \\
\text { per cm of culm length of second lowest internodes }\end{array}$} \\
\hline \multirow{2}{*}{$\begin{array}{l}\text { Cereal *), } \\
\text { exp., year } \\
\text { and harvest } \\
\text { date }\end{array}$} & \multirow{2}{*}{$\begin{array}{c}\text { Rate of } \\
\text { seeding, } \\
\text { kg per } \\
\text { ha }\end{array}$} & \multirow{2}{*}{$\begin{array}{l}\text { Spac- } \\
\text { ing, } \\
\mathrm{cm}\end{array}$} & \multirow{2}{*}{$\begin{array}{c}\mathrm{Kg} \mathrm{N} \\
\text { per } \\
\text { ha }\end{array}$} & \multicolumn{2}{|c|}{$\begin{array}{l}\text { Lodging } \\
\text { index }\end{array}$} & \multicolumn{3}{|c|}{$\begin{array}{l}\text { Weight per } \mathrm{cm} \text { of } \\
\text { culm length, } \mathbf{m g}\end{array}$} \\
\hline & & & & $\overline{\text { date }}$ & date & $\left.5^{* *}\right)$ & $6 * *)$ & $7 * * 1$ \\
\hline Winter rye, & & & & $2 x .6$ & 78.7 & & & \\
\hline 612,1941 & 150 & 33 & 60 & 0 & 2 & - & $18.7 \pm 1.1$ & $19.0 \pm 3.0$ \\
\hline \multirow[t]{6}{*}{ Aug. 5} & 150 & 33 & 180 & 0 & 3 & $14.1 \pm 1.0$ & $16.0 \pm 1.0$ & - \\
\hline & 150 & 11 & 60 & 0 & 3 & $12.0 \div 1.5$ & $18.1 \pm 0.9$ & $15.7 \pm 1.7$ \\
\hline & 150 & 11 & 180 & $1 \frac{1}{2}$ & 6 & - & $14.5 \pm 0.8$ & $16.5 \pm 1.4$ \\
\hline & 300 & 33 & 60 & 0 & $4 \frac{1}{2}$ & - & $13.9 \pm 0.1$ & $14.4 \pm 0.1$ \\
\hline & 300 & 33 & 180 & $3 \frac{1}{2}$ & 7 & $14.1 \pm 1.8$ & $18.0 \pm 1.3$ & 二 \\
\hline & 300 & 11 & 60 & 2 & 8 & - & $17.2 \pm 0.2$ & - \\
\hline \multirow{6}{*}{$\begin{array}{l}\text { Winter rye, } \\
659,1942, \\
\text { Aug. } 18\end{array}$} & & & & 58.7 & 22.8 & & & \\
\hline & 75 & 33 & 80 & 6 & 5 & $15.5 \div 0.9$ & $18.3 \pm 0.8$ & $20.3 \pm 3.6$ \\
\hline & 75 & 11 & 80 & 3 & $3 \frac{1}{8}$ & $15.2 \pm 0.7$ & $20.0 \pm 0.8$ & $22.0 \pm 0.9$ \\
\hline & 150 & 33 & 80 & 5 & 3 & - & $15.0 \pm 0.7$ & $11.4 \pm 1.1$ \\
\hline & 300 & 33 & 80 & $8 \frac{1}{2}$ & 7 & $9.9 \pm 1.2$ & $12.4 \pm 0.5$ & $12.5 \pm 0.8$ \\
\hline & 300 & 11 & 80 & $8 \frac{1}{2}$ & 7 & - & $10.7 \pm 0.5$ & $9.0 \pm 1.1$ \\
\hline \multirow{6}{*}{$\begin{array}{l}\text { Summer } \\
\text { wheat, } 658 \text {, } \\
\text { 1942, Sept. } 3\end{array}$} & & & & 14.7 & 28.8 & & & \\
\hline & 75 & 33 & 40 & $\frac{1}{2}$ & 0 & $19.0 \pm 0.7$ & $20.9 \pm 1.8$ & - \\
\hline & 75 & 33 & 120 & 0 & $\frac{1}{2}$ & $18.0 \neq 1.0$ & $23.6 \pm 0.9$ & - \\
\hline & 150 & 33 & 40 & 0 & 0 & $15.3 \pm 0.8$ & $17.5 \div 0.9$ & - \\
\hline & 150 & 33 & 120 & 0 & $2 \frac{1}{8}$ & $15.6 \pm 0.7$ & $16.5 \pm 1.0$ & - \\
\hline & 300 & 11 & 120 & 9 & 8 & $13.8 \pm 1.1$ & $12.7 \pm 0.2$ & - \\
\hline
\end{tabular}

*) Culms collected: Exp. 612 two weeks, Exp. 659 four weeks, Exp. 658 one week before harvesting.

**) Culms with 5, 6 and 7 internodes respectively.

the sclerenchymatous zone was also reduced in the densely sown wheat plants.

Thickness of sclerenchyma cell walls was reduced by increased density of the crop. It was slightly affected by increased nitrogen nutrition in the case of the rye plants but not in the case of the wheat (cf Table IX).

2. Pot experiment with oats. In this experiment the combined effect of potassium supply, nitrogen nutrition and illumination of the plants on growth and yield of oats has been studied. Although a full report of the results of this experiment will be given elsewhere, the measurements of those plant characters which are related to tendency to lodging will be recorded in this paper. 


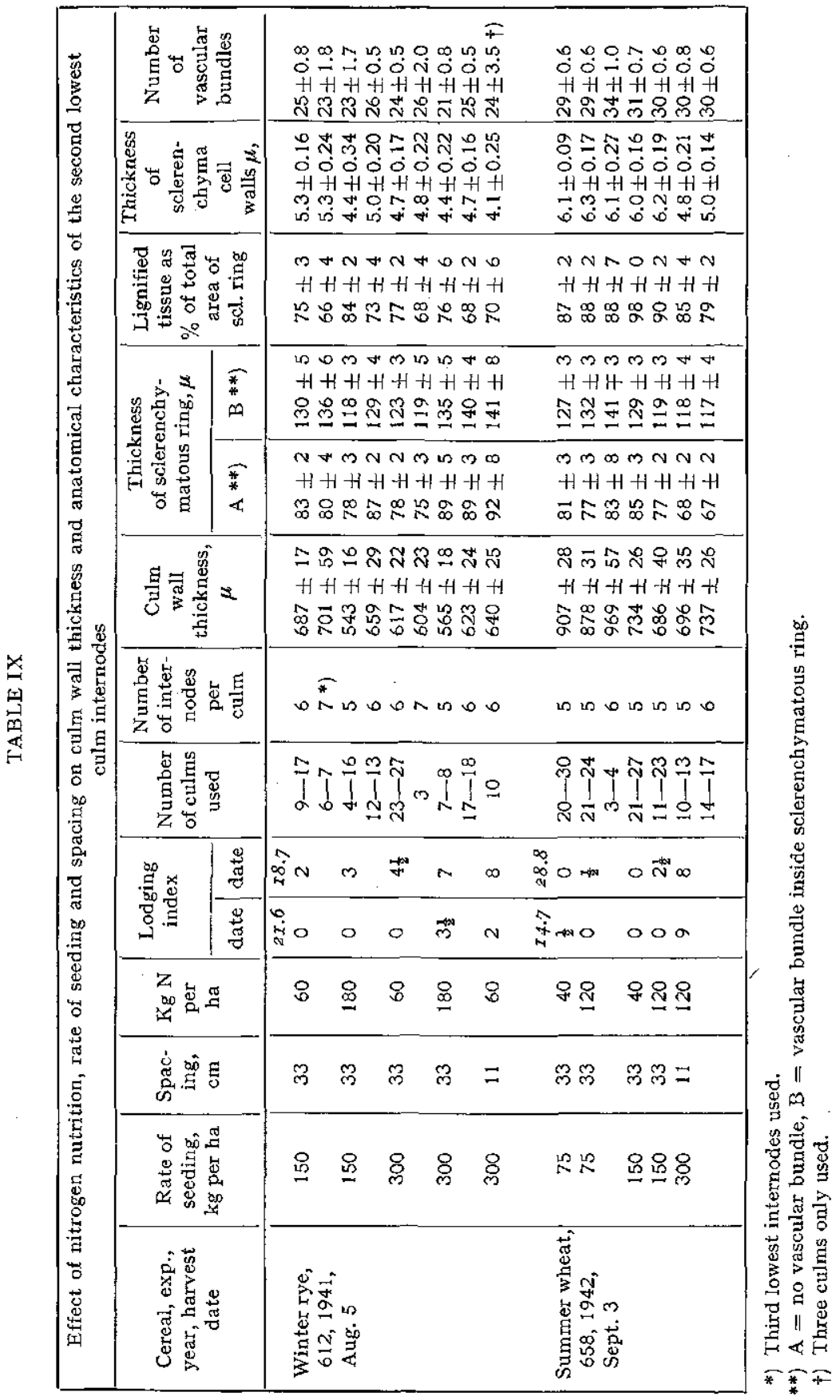


The Mitscherlich pots used contained approximately $5 \mathrm{~kg}$ of a potassiumdeficient sandy soil of $\mathrm{pH}$ 5.2. Potassium was supplied in amounts of 0.5 , 1.0 and $3.0 \mathrm{~g} \mathrm{~K}_{2} \mathrm{SO}_{4}$ per pot, nitrogen in amounts of 175,350 and $1050 \mathrm{mg}$ $N$ per pot in the form of either calcium nitrate or ammonium sulphate. Further dressings consisted of monocalcium phosphate, magnesium sulphate and copper sulphate.

There was a considerable difference between oats growing in the unshaded and those in the shaded part of the greenhouse. In both cases the plants responded to the K-dressings. The requirement for nitrogen of the unshaded plants was considerably higher than that of the shaded ones, indicating a difference in the rate of carbon dioxide assimilation. The highest applications of nitrogen in the form of ammonium sulphate depressed the yield in the case of the shaded plants.

\section{Pot experiment 1941}
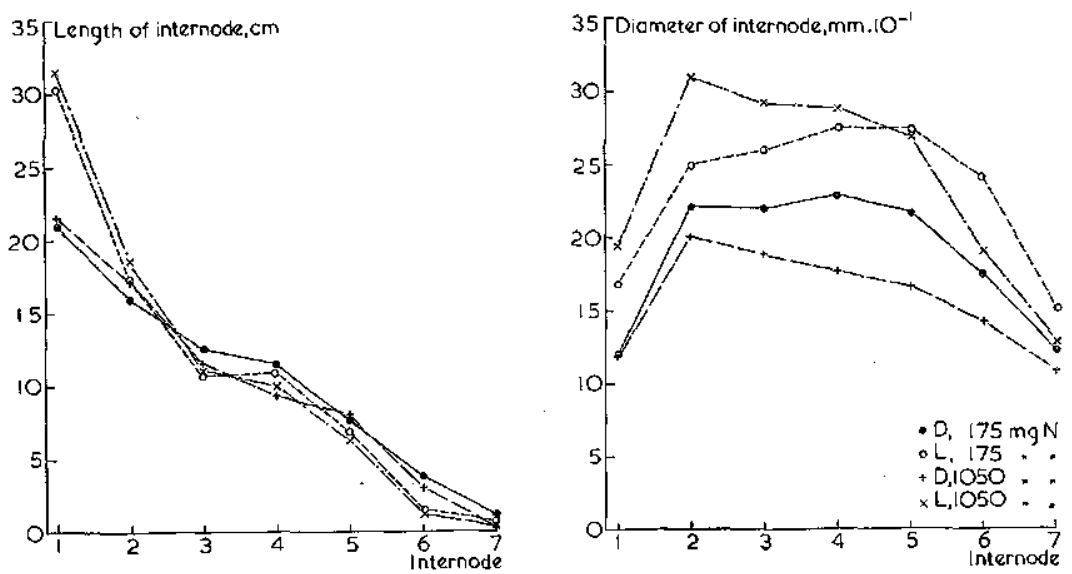

Fig. 11. Effect of illumination and nitrogen nutrition on length and diameter of internodes of oat culms. $\mathrm{N}$ in the form of ammonium sulphate. $\mathrm{D}=$ shaded, $\mathrm{L}=$ unshaded, $1 \mathrm{st}=$ highest internode.

The effect of nitrogen nutrition and exposure to light on length of internodes is demonstrated in Fig. 11. It will be seen that the length of the lower internodes was not increased by the nitrogen dressings. Shading, however, resulted in the formation of considerably longer lower internodes than were found in plants exposed to bright sunshine. In agreement with the results of the abovementioned field experiments 612,658 and 659, this pot experiment shows that the elongation of the lower internodes of cereal plants 
as often observed in nitrogen-dressed fields is not a direct effect of improved nitrogen nutrition but is due to an indirect shading effect.

The negative correlation between length of lower and upper internodes as observed more or less clearly in the above-mentioned field experiments again is found in this pot experiment. Shaded plants have considerably shorter upper internodes than unshaded ones.

The number of internodes was not increased by shading or by increased nitrogen supply. Generally it was somewhat higher in the illuminated plants. This is in contrast with the results obtained on a number of experimental fields. Plants supplied with ammonium sulphate tended to have more internodes than those with calcium nitrate.

Culm diameter was considerably reduced in the shaded plants as compared with the unshaded ones (Fig. 11). This was the case with both upper and lower internodes. Excessive amounts of ammonium sulphate likewise reduced the internode diameter throughout the culm in the shaded plants. In the unshaded plants the diameter of the basal internodes was reduced but that of the higher ones was increased by excessive amounts of ammonium sulphate. Calcium

TABLE X

\begin{tabular}{|c|c|c|c|c|}
\hline \multicolumn{2}{|c|}{ Nitrogen } & \multirow{2}{*}{ Illumination } & \multicolumn{2}{|c|}{$\begin{array}{l}\text { Weight per } \mathrm{cm} \text { of culm } \\
\text { length, } \mathrm{mg}\end{array}$} \\
\hline mg per pot & compound & & $6 * * * 1)$ & $7 * * * 1$ \\
\hline 175 & as $*$ & $D * *$ & $4.1 \pm 0.2$ & $4.1 \pm 0.1$ \\
\hline 175 & as & $\mathrm{L}$ & - & $7.1 \pm 0.3$ \\
\hline 350 & as & $\mathrm{D}$ & $3.6 \pm 0.2$ & $3.7 \pm 0.2$ \\
\hline 350 & as & $\mathrm{L}$ & - & $7.8 \pm 0.2$ \\
\hline 1050 & as & D & $3.8 \pm 0.3$ & $3.4 \pm 0.2$ \\
\hline 1050 & as & $\mathrm{L}$ & $7.2 \pm 0.3$ & $7.0 \pm 0.2$ \\
\hline 175 & $\mathrm{cn}$ & $\mathrm{D}$ & $4.0 \pm 0.1$ & $3.9 \pm 0.1$ \\
\hline 175 & $\mathrm{cn}$ & L & 一 & $7.3 \pm 0.2$ \\
\hline 350 & cn & $\mathrm{D}$ & $4.4 \pm 0.2$ & $5.1 \pm 0.4$ \\
\hline 350 & $\mathrm{cn}$ & $\mathrm{L}$ & - & $8.0 \pm 0.2$ \\
\hline 1050 & $\mathrm{cn}$ & $\mathrm{D}$ & $4.9 \pm 0.2$ & $4.4 \pm 0.4$ \\
\hline 1050 & $\mathrm{cn}$ & L & $7.3 \pm 0.4$ & $8.2 \pm 0.3$ \\
\hline
\end{tabular}

*) as $=$ ammonium sulphate, $\mathrm{cn}=$ calcium nitrate.

**) $\mathrm{D}=$ shaded, $\mathrm{L}=$ unshaded.

***) Culms with 6 and 7 internodes respectively. 
nitrate gave similar results in this respect both in shaded and unshaded plants but the differences were less striking.

Weight per $\mathrm{cm}$ of culm length was much lower in the shaded plants than in those grown in sunlight. This was due partly to reduced culm diameter, partly to reduced culm wall thickness and partly to reduced lignification of the lower internodes (see Tables $\mathrm{X}$ and $\mathrm{XI}$ ). In the shaded plants increasing amounts of nitrogen in the form of ammonium sulphate caused a slight reduction in culm weight.

Culm wall thickness was markedly reduced by shading of the plants. Excessive amounts of nitrogen accentuated this effect. In the unshaded plants high amounts of nitrogen tended to increase the culm wall thickness (Table XI).

Rate of lignification of the culms was determined microscopically in transverse sections as well as chemically. Both thickness of sclerenchymatous layer and thickness of the sclerenchyma cell walls were found to be considerably reduced by shading of the plants as well as by increased nitrogen supply. The results of the chemical analyses were in general agreement with the microscopical observations (cf Tables XI and XII).

Excessive nitrogen has reduced the lignin content of shaded plants to a much higher degree than that of unshaded plants.

TABLE XI

\begin{tabular}{|c|c|c|c|c|c|c|c|c|c|}
\hline \multicolumn{10}{|c|}{$\begin{array}{l}\text { Effect of nitrogen nutrition and illumination on culm wall thickness and anato- } \\
\text { mical characteristics of the second lowest culm internodes of oat plants (pot } \\
\text { experiment 1941) }\end{array}$} \\
\hline \multirow[t]{2}{*}{$\begin{array}{l}\mathrm{N} *) \\
\mathrm{mg} \\
\text { per } \\
\text { pot }\end{array}$} & \multirow[t]{2}{*}{$\begin{array}{l}\text { Illum- } \\
\text { ina- } \\
\text { tion }\end{array}$} & \multirow[t]{2}{*}{$\begin{array}{l}\text { Num- } \\
\text { ber of } \\
\text { culms } \\
\text { used }\end{array}$} & \multirow{2}{*}{$\begin{array}{l}\text { Num- } \\
\text { ber of } \\
\text { inter- } \\
\text { nodes } \\
\text { per } \\
\text { culm }\end{array}$} & \multirow[t]{2}{*}{$\begin{array}{c}\text { Culm } \\
\text { wall } \\
\text { thick- } \\
\text { ness, } \mu\end{array}$} & \multicolumn{2}{|c|}{$\begin{array}{c}\text { Thickness } \\
\text { of scleren- } \\
\text { chymatous } \\
\text { ring, } \mu\end{array}$} & \multirow[t]{2}{*}{$\begin{array}{c}\text { Lignified } \\
\text { tissue as } \\
\% \text { of total } \\
\text { area of } \\
\text { scl. ring }\end{array}$} & \multirow[t]{2}{*}{$\begin{array}{c}\text { Thickness } \\
\text { of scleren- } \\
\text { chyma } \\
\text { cell } \\
\text { walls, } \mu\end{array}$} & \multirow[t]{2}{*}{$\begin{array}{l}\text { Number } \\
\text { of vas- } \\
\text { cular } \\
\text { bundles }\end{array}$} \\
\hline & & & & & $A+1$ & B & & & \\
\hline \multirow[t]{2}{*}{175} & $\left.D^{* *}\right)$ & 8 & 6 & $466 \pm \overline{18}$ & $41 \pm 2$ & 8 & & & $16 \pm 0.8$ \\
\hline & & & & & & & & & \\
\hline 175 & L & $33-$ & 7 & $9 \pm 11$ & 47 」 & $97 \pm 2$ & & & $22 \pm$ \\
\hline \multirow[t]{2}{*}{1050} & D & $2-4$ & 6 & $2 \pm 14$ & $38 \pm 6$ & $90 \pm 0$ & & 5 & $4 \pm 0.3$ \\
\hline & & $9-14$ & 7 & $394 \pm 12$ & $32 \pm 2$ & $78 \pm 4$ & $50 \pm 3$ & 18 & $19 \pm 0.5$ \\
\hline \multirow[t]{2}{*}{1050} & $\mathrm{~L}$ & 7 & 6 & $0 \pm 15$ & $47 \pm 3$ & $99 \pm$ & $46 \pm$ & & 20.0 \\
\hline & & $24-28$ & 7 & $497 \pm 20$ & $43 \pm 1$ & $91 \pm 4$ & $54 \pm 2$ & $2.7 \pm 0.07$ & $21 \pm 0.6$ \\
\hline
\end{tabular}

*) as $\left(\mathrm{NH}_{4}\right)_{2} \mathrm{SO}_{4}$.

**) $\mathrm{D}=$ shaded, $L=$ unshaded.

†) $\mathrm{A}=$ no vascular bundle, $\mathrm{B}=$ vascular bundle inside sclerenchymatous ring. 
The number of vascular bundles was slightly reduced by shading the plants (Table XI).

TABLE XII

\begin{tabular}{|c|c|c|c|c|c|}
\hline \multicolumn{6}{|c|}{$\begin{array}{c}\text { Effect of nitrogen nutrition and illumination on lignin content of oat culms (pot } \\
\text { experiment 1941) }\end{array}$} \\
\hline \multicolumn{2}{|c|}{ Nitrogen } & \multirow{2}{*}{$\begin{array}{l}\text { Illumi- } \\
\text { nation }\end{array}$} & \multicolumn{3}{|c|}{ Lignin in internodes, $\%$ of dry matter $\dagger$ ) } \\
\hline mg per pot & compound & & 5th & 4th & $3 \mathrm{rd}$ \\
\hline 175 & as *) & $\mathrm{D} * *)$ & 20.8 & 22.6 & 22.3 \\
\hline 175 & $n$ & $\mathbf{L}$ & 21.7 & 22.0 & 22.2 \\
\hline 1050 & $"$ & $\mathbf{D}$ & 7.9 & 16.9 & 17.0 \\
\hline 1050 & ," & L & 21.2 & 23.4 & 23.1 \\
\hline 175 & en & D & 18.6 & 19.9 & 19.5 \\
\hline 175 & ," & $\mathrm{L}$ & 22.1 & 21.9 & 21.4 \\
\hline 1050 & , & D & 10.5 & 11.3 & 14.5 \\
\hline 1050 & , & L & 20.8 & 22.7 & 22.9 \\
\hline
\end{tabular}

*) as = ammonium sulphate, cn = calcium nitrate.

**) $\mathrm{D}=$ shaded, $\mathrm{L}=$ unshaded.

f) averages of duplicate values.

The results of the field and pot experiments recorded in this section show that the unfavourable effect of excessive nitrogen on the strength of the lower internodes of cereal plants is due partly to an indirect shading effect resulting from an abundant leaf formation and partly to a direct nutritional effect. Elongation of the lower internodes depends entirely on the shading effect. Reduction of culm diameter, of culm wall thickness and of lignification may be brought about by shading as well as by a direct nitrogen effect.

\section{EFFECT OF POTASSIUM NUTRITION}

The effect of potassium nutrition on lodging has been studied on a number of experimental fields with rye, barley and wheat. The soils on which these experiments had been laid out, were in general poor in potassium so that plant growth was reduced considerably by $\mathrm{K}$-deficiency when potassium dressings were omitted. The influence of K-supply on lodging was tested by applying increasing amounts of nitrogenous fertilisers at different $\mathrm{K}$-levels: no $\mathrm{K}$, moderate, normal and excessive amounts of added potassium salts respectively.

Although in some cases the plants dressed with potassium lodged more severely than those without a K-dressing (Fig. 12), this was probably due to the fact that the latter suffered from potassium 
deficiency so that a far less heavy and dense crop was formed. The straw of potassium-deficient plants appeared to be more brittle as a result of which breaking of the culms occurred much more frequently than was the case with fully dressed plants. These breakages

\section{RYE}

\section{Exp. Field 589}

1941
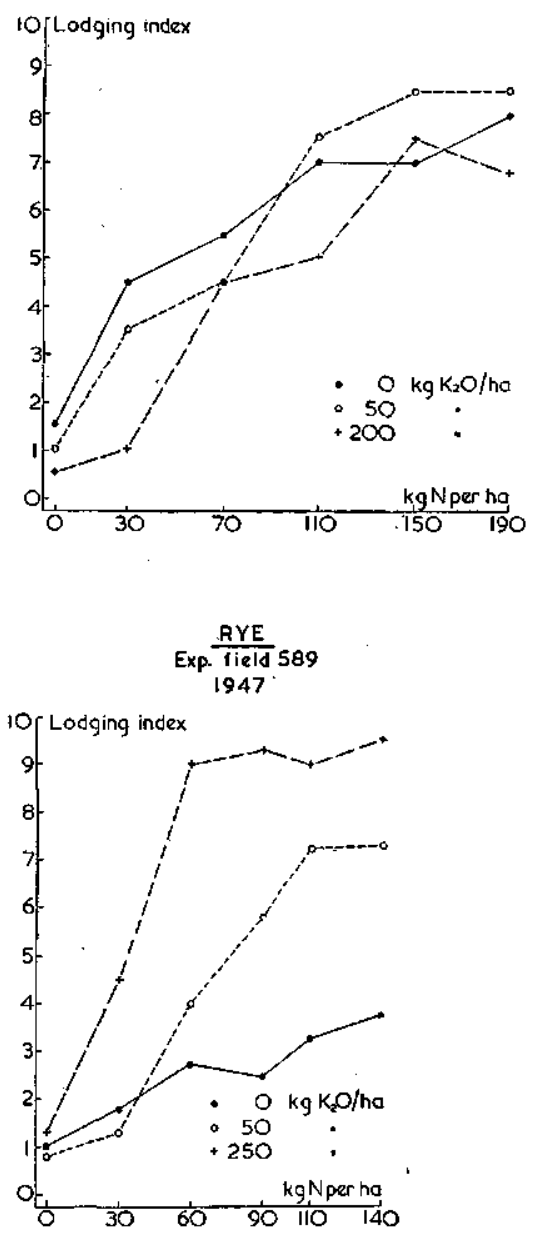

1943

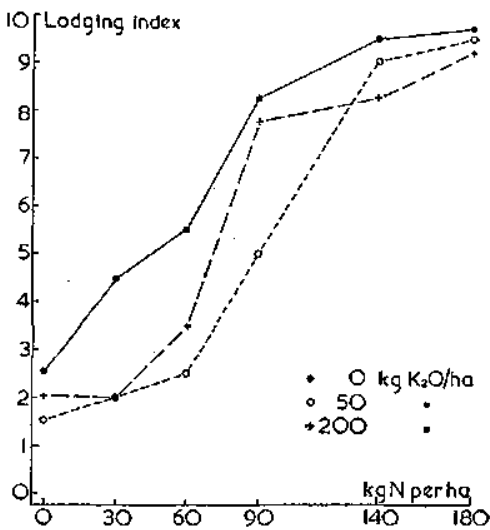

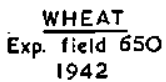

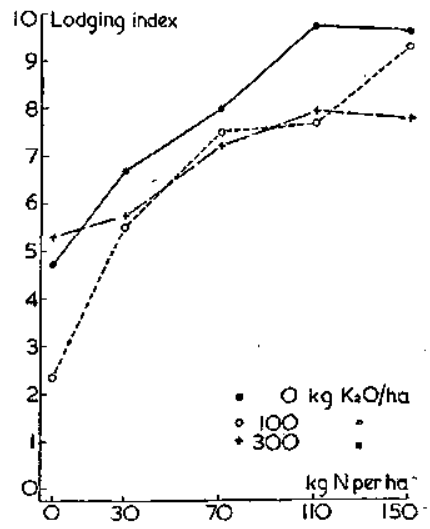

Fig. 12. Effect of potassium and nitrogen nutrition on lodging of winter rye (in three different years) and of summer wheat. Lodging indices determined 14 (Exp. 589, 1941), 11 (Exp. 589, 1943), 20 (Exp. 589, 1947) and 35 (Exp. 650, 1942) days respectively before harvesting. 
E.xp. field 589,1947
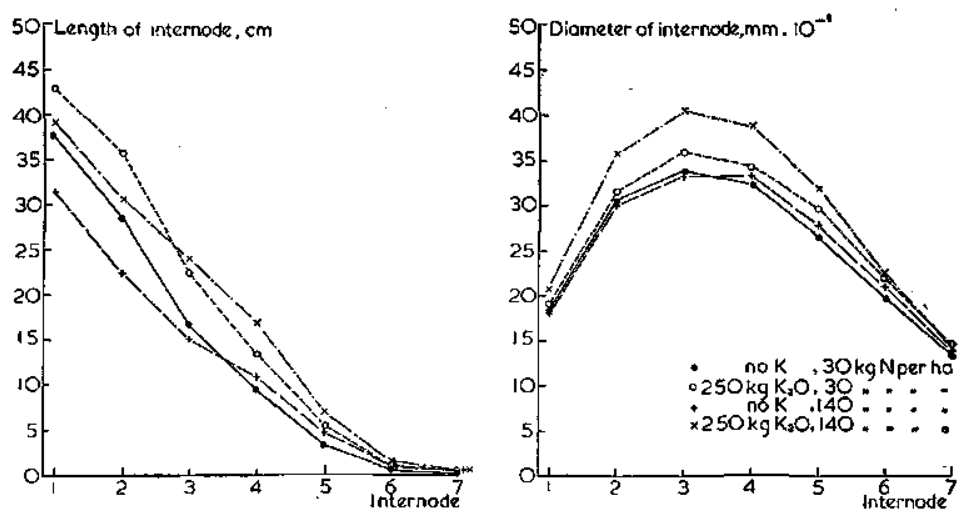

WHEAT

Exp. field 650,1942
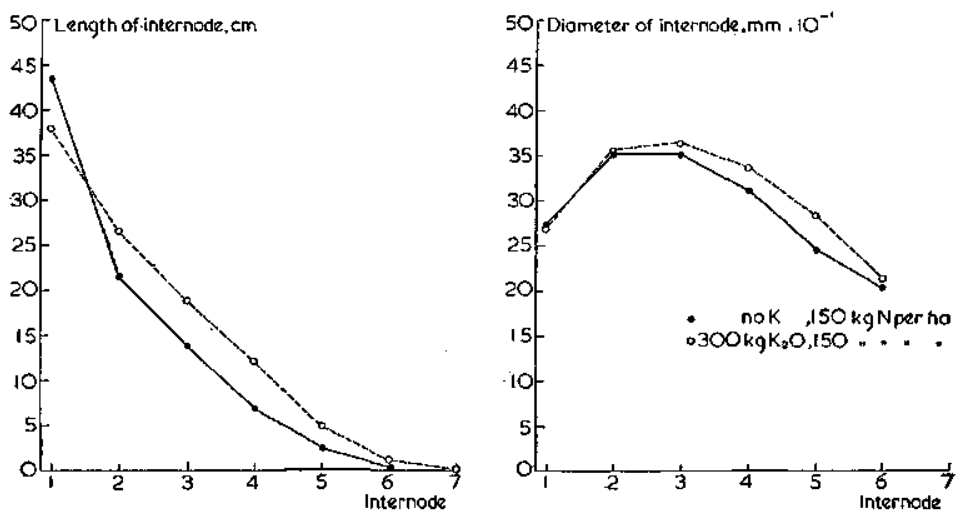

Pot experiment 194i
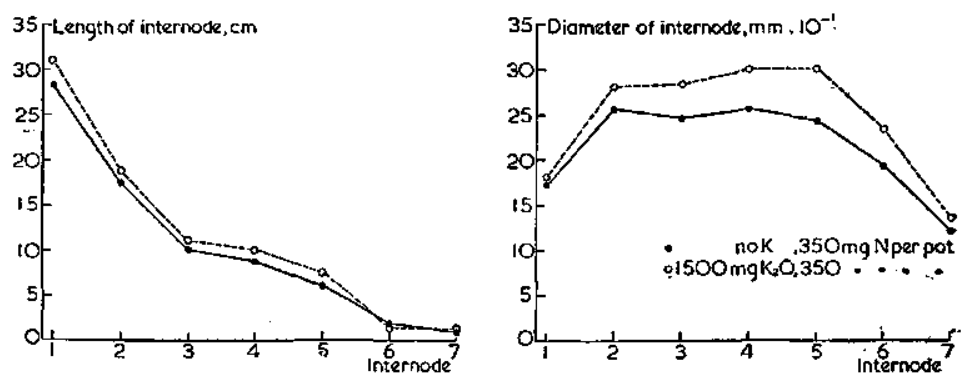

Fig. 13. Effect of potassium nutrition on length and diameter of culm internodes of winter rye, summer wheat and oats. For lodging data see

Figure 12. 
TABLE XIII

\begin{tabular}{|c|c|c|c|c|c|c|c|}
\hline \multicolumn{8}{|c|}{ Effect of potassium nutrition of cereal plants on weight per $\mathrm{cm}$ of cuIm length } \\
\hline \multirow{3}{*}{$\begin{array}{l}\text { Cereal }{ }^{*} \text { ), } \\
\text { experi- } \\
\text { ment } \\
\text { and soil }\end{array}$} & \multirow{3}{*}{$\begin{array}{c}\mathrm{K}_{2} \mathrm{O}, \mathrm{kg} \\
\text { per ha, or } \\
\text { mg per pot }\end{array}$} & \multicolumn{2}{|c|}{ Nitrogen } & \multirow{3}{*}{$\begin{array}{l}\text { Illumi- } \\
\text { nation }\end{array}$} & \multirow{2}{*}{\multicolumn{3}{|c|}{$\begin{array}{l}\text { Weight per cm of culm length, } \\
\text { 2nd lowest internode } \dagger \dagger), \mathrm{mg}\end{array}$}} \\
\hline & & \multirow{2}{*}{$\begin{array}{c}\text { kg per ha } \\
\text { or mg } \\
\text { per pot }\end{array}$} & \multirow{2}{*}{$\begin{array}{c}\text { com- } \\
\text { pound }\end{array}$} & & & & \\
\hline & & & & & 5 & $\frac{6}{6}$ & 7 \\
\hline Oats, & 0 & 350 & as ***) & $\mathrm{D} \dagger$ & - & - & $3.1 \pm 0.2$ \\
\hline pot exp., & 0 & 350 & , & L & - & - & $5.5 \pm 0.2$ \\
\hline 1941 & 0 & 350 & $\mathrm{cn}$ & $\mathrm{D}$ & - & $3.2 \pm 0.1$ & - \\
\hline sandy & 0 & 350 & ," & L & - & $5.5 \pm 0.4$ & $5.3 \pm 0.2$ \\
\hline & 1500 & 350 & as & D & - & $3.6 \pm 0.2$ & $3.7 \pm 0.2$ \\
\hline & 1500 & 350 & , & $\mathbf{L}$ & - & - & $7.8 \pm 0.2$ \\
\hline & 1500 & 350 & cn & D & - & $4.4 \pm 0.2$ & $5.1 \pm 0.4$ \\
\hline & 1500 & 350 & ", & L & - & - & $8.0 \pm 0.2$ \\
\hline Wheat, & 0 & 0 & - & 一 & $14.3 \pm 1.0$ & $18.1 \pm 1.4$ & - \\
\hline field exp. & $0(100) * *)$ & 0 & - & - & $13.6 \pm 0.8$ & $16.6 \pm 0.7$ & - \\
\hline 650,1942 & $100(300)$ & 0 & - & - & $14.2 \pm 0.8$ & $15.1 \pm 1.0$ & - \\
\hline sandy & $300(600)$ & 0 & - & - & $12.6 \pm 0.5$ & $15.7 \pm 1.5$ & - \\
\hline & 0 & 150 & anl & - & $15.3 \pm 0.8$ & $13.3 \pm 0.9$ & - \\
\hline & $0(100)$ & 150 & ," & - & $14.9 \pm 0.8$ & $14.6 \pm 1.1$ & - \\
\hline & $100(300)$ & 150 & , & - & $12.8 \pm 1.3$ & $14.2 \pm 1.1$ & 一 \\
\hline & $300(600)$ & 150 & , & - & $15.6 \pm 1.6$ & $14.7 \pm 0.5$ & $11.8 \pm 0.3$ \\
\hline
\end{tabular}

*) Oat culms collected when the plants were ripe, wheat culms four weeks before harvesting.

**) Figures in brackets refer to K-dressings in 1941 .

***) as = ammonium sulphate, $\mathrm{cn}=$ calcium nitrate, anl $=$ ammonium nitrate limestone.

†) $\mathrm{D}=$ shaded, $\mathrm{L}=$ unshaded.

††) Culms with 5, 6 and 7 internodes respectively.

occurred not only at the lower internodes but also at higher ones. When a comparison was made between plants treated with a moderate and an excessive amount of potassium, no difference in lodging could be detected. This does not indicate a strengthening effect of large amounts of potassium on the culm of cereals as is sometimes stated in the literature ${ }^{35}$ ). It is an agreement with the results obtained by $\mathrm{Krant} z$ and $\mathrm{Ch}$ and $\mathrm{ler}{ }^{23}$ ) in field experiments with maize.

The effect of K-nutrition on various plant characters related to standing ability of cereal plants is given in Tables XIII-XV and in Fig. 13. It will be seen that K-deficient plants in general had shorter internodes than plants treated amply with potassium. This applies to the lower as well as to the upper internodes (Fig. 13). 
TABLE XIV

Effect of potassium nutrition on wall thickness and anatomical characteristics of the second lowest culm internodes

\begin{tabular}{|c|c|c|c|c|c|c|c|c|c|c|c|c|}
\hline \multirow[t]{2}{*}{ Cereal *) } & \multirow[t]{2}{*}{$\begin{array}{l}\text { Exp. } \\
\text { and } \\
\text { year }\end{array}$} & \multirow[t]{2}{*}{$\begin{array}{c}\mathrm{Kg} \\
\mathrm{K}_{2} \mathrm{O} \\
\text { per } \\
\text { ha }\end{array}$} & \multirow[t]{2}{*}{$\begin{array}{l}\mathrm{Kg} \\
\mathrm{N} \\
\text { per } \\
\text { ha }\end{array}$} & \multirow[t]{2}{*}{$\begin{array}{l}\text { Lodged } \\
\text { (I) or } \\
\text { erect(e) }\end{array}$} & \multirow[t]{2}{*}{$\begin{array}{l}\text { Num- } \\
\text { ber of } \\
\text { culms } \\
\text { used }\end{array}$} & \multirow[t]{2}{*}{$\begin{array}{l}\text { Num- } \\
\text { ber of } \\
\text { inter- } \\
\text { nodes } \\
\text { per } \\
\text { culm }\end{array}$} & \multirow[t]{2}{*}{$\begin{array}{l}\text { Culm } \\
\text { wall } \\
\text { thick- } \\
\text { ness, } \\
\mu\end{array}$} & \multicolumn{2}{|c|}{$\begin{array}{l}\text { Thickness } \\
\text { of scleren- } \\
\text { chymatous } \\
\text { ring, } \\
\mu\end{array}$} & \multirow[t]{2}{*}{$\left|\begin{array}{c}\text { Lignified } \\
\text { tissue as } \\
\% \text { of total } \\
\text { area of } \\
\text { sclerenchy- } \\
\text { matous } \\
\text { ring }\end{array}\right|$} & \multirow[t]{2}{*}{$\begin{array}{c}\text { Thickness } \\
\text { of scleren- } \\
\text { chyma } \\
\text { cell walls, } \\
\mu\end{array}$} & \multirow[t]{2}{*}{$\begin{array}{c}\text { Number } \\
\text { of vas- } \\
\text { cular } \\
\text { bundles }\end{array}$} \\
\hline & & & & & & & & $\overline{A+1}$ & $\overline{B+1}$ & & & \\
\hline \multirow{2}{*}{$\begin{array}{l}\text { Winter } \\
\text { rye }\end{array}$} & 589 & 0 & 140 & e & 60 & - & $545 \pm 14 \mid$ & $62 \pm 1$ & - & - & $2.4 \pm$ & - \\
\hline & 1947 & 250 & 140 & 1 & $59-60$ & - & $726 \pm 17$ & $64 \pm 1$ & - & - & $2.5 \pm 0.10$ & 一 \\
\hline \multirow{4}{*}{$\begin{array}{c}\text { Summer } \\
\text { wheat }\end{array}$} & 650 & 0 & 150 & 1 & $13-14$ & 5 & $779 \pm 31$ & $89 \pm 4$ & $132 \pm 4$ & $90 \pm 2$ & $4.7 \pm 0.25$ & $24 \pm 0.7$ \\
\hline & 1942 & & & & $5-12$ & 6 & $715 \pm 40$ & $98 \pm 3$ & $149 \pm 6$ & $88 \pm 3$ & $4.5 \pm 0.27$ & $27 \pm 1.2$ \\
\hline & & 300 & 150 & I & $22-24$ & 5 & $649 \pm 24$ & $81 \pm 3$ & $125 \pm 4$ & $93 \pm 2$ & $4.6 \pm 0.15$ & $26 \pm 0.5$ \\
\hline & & & & & $44-48$ & 6 & $724 \pm 20 \mid$ & $90 \pm 3$ & $130 \pm 3$ & $81 \pm 2$ & $5.2 \pm 0.13$ & $26 \pm 0.3$ \\
\hline
\end{tabular}

*) Culms collected: Exp. 589 two weeks, Exp. 650 four weeks before harvesting.

†) A: no vascular bundle, B: vascular bundle inside sclerenchymatous ring.

TABLE XV

\begin{tabular}{|c|c|c|c|c|c|}
\hline Cereal & $\begin{array}{l}\text { Experiment } \\
\text { year and } \\
\text { soil }\end{array}$ & $\begin{array}{l}\mathrm{Kg} \mathrm{K}_{2} \mathrm{O} \\
\text { applied } \\
\text { per ha }\end{array}$ & $\begin{array}{c}\mathrm{Kg} \mathrm{N} \\
\text { per } \\
\text { ha }\end{array}$ & $\begin{array}{l}\text { Lodged(1) } \\
\text { or } \\
\operatorname{erect}(\mathrm{e})\end{array}$ & $\begin{array}{c}\text { Lignin, } \\
\% \text { of } \\
\text { dry matter }\end{array}$ \\
\hline \multirow[t]{6}{*}{ Winter rye $\dagger$ ) } & 589 , & 0 & 0 & e & $25.5 \pm 0.35$ \\
\hline & 1947, & 250 & 0 & e & $19.3 \pm 0.07$ \\
\hline & sandy & 0 & 30 & $\mathrm{e}$ & $22.2 \pm 0.14$ \\
\hline & & 250 & 30 & $\mathrm{e}$ & $19.3 \pm 0.28$ \\
\hline & & 0 & 140 & $1 * *)$ & $22.8 \pm 0.31$ \\
\hline & & 250 & 140 & 1 & $16.0 \pm 0.12$ \\
\hline \multirow[t]{8}{*}{ Summer wheat $\uparrow \dagger$ ) } & 650 , & 0 & 0 & e & $18.4 \pm 0.15$ \\
\hline & 1942 & $0(100) *)$ & 0 & e & $17.1 \pm 0.10$. \\
\hline & peaty & $100(300)$ & 0 & $\mathrm{e}$ & $11.3 \pm 0.32^{\circ}$ \\
\hline & & $300(600)$ & 0 & $\mathrm{e}$ & $15.7 \pm 0.17$ \\
\hline & & 0 & 150 & 1 & $18.2 \pm 0.57$ \\
\hline & & $0(100)$ & 150 & 1 & $17.5 \pm 0.68$ \\
\hline & & $100(300)$ & 150 & 1 & $16.4 \pm 0.16$ \\
\hline & & $300(600)$ & 150 & 1 & $14.3 \pm 0.43$ \\
\hline
\end{tabular}

t) Second lowest internodes, collected two weeks before harvesting.

$\left.t_{\dagger}\right)$ Third lowest internodes, collected four weeks before harvesting.

*) Figures in brackets refer to K-dressings in 1941.

**) Lodging index $=5$. 
Culm diameter was clearly reduced in potassium-deficient plants.

Weight per $\mathrm{cm}$ of basal culm was lower in $\mathrm{K}$-deficient oats than in plants with a normal K-supply (pot experiment 1942). This was apparently due to the reduced culm diameter of the potassiumdeficient plants (Table XIII). In the case of wheat K-deficient culms were slightly heavier than those treated with potassium. This may have been due to the somewhat thicker culm walls and the somewhat thicker sclerenchyma zone in the K-deficient plants. In the rye plants of Exp. 589 potassium deficiency gave a highly significant reduction of culm wall thickness (Table XIV).

Thickness of lignified cell walls tended to be slightly reduced in the case of potassium deficiency.

The effect of potassium on lignin content of basal culm internodes is demonstrated in Table XV. In general the plants with the lowest potassium supply have the highest lignin content.

\section{EFFECT OF PHOSPHORUS NUTRITION}

The effect of phosphorus on the standing ability of cereal plants has been studied on some experimental fields laid out on P-deficient
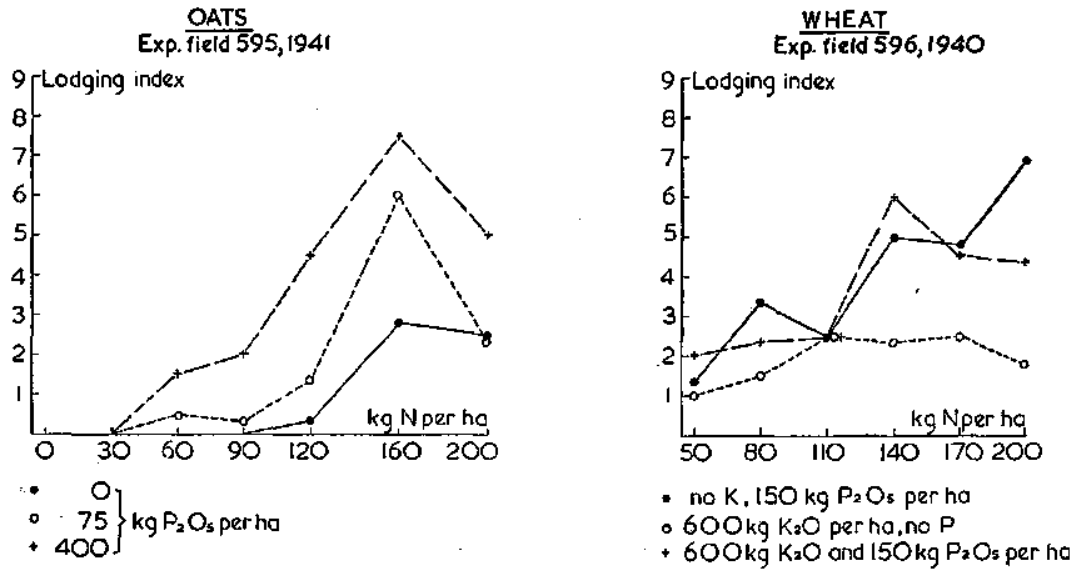

Fig. 14. Effect of phosphorus and nitrogen nutrition on lodging of oats and summer wheat. Lodging indices determined 15 (Exp. 595) and 42 (Exp. 596) days respectively before harvesting.

soils. On these areas increasing amounts of nitrogenous fertilisers were applied at different P-levels in the soil. From the results of 
these field experiments as well as from those of pot experiments no particular effect of phosphorus supply on the standing capacity of the plants could be observed. The P-deficient plants lodged less severely than those dressed amply with phosphate apparently due to a poorer development (Fig. 14).

The effect of phosphorus deficiency on anatomical characters was studied in oat and wheat plants grown in a pot experiment. Since the soil used in this experiment was extremely poor in available phosphorus, plants treated with moderate and high amounts of fertiliser phosphorus were investigated. The yields of the phosphorus-deficient wheat plants were approximately $30 \%$ of the yields of plants dressed with adequate phosphorus. In the case of oats these figures were $30 \%$ (at $0.6 \mathrm{~g}$ phosphate per pot) and $60 \%$ (at $1.0 \mathrm{~g}$ phosphate).

Culm wall thickness was clearly reduced in the phosphorus-deficient plants. In oats this was only the case at the lowest nitrogen level (see Table XVI).

Thickness of the sclerenchymatous ring was likewise reduced in the phosphorus-deficient wheat plants but not in the oat plants. Thickness of the sclerenchyma cell walls was unaffected by the phosphorus supply.

Number of vascular bundles, however, was significantly reduced

TABLE XVI

\begin{tabular}{|c|c|c|c|c|c|c|c|c|c|c|}
\hline \multirow[t]{2}{*}{ Cereal } & \multirow[t]{2}{*}{$\begin{array}{c}\mathrm{Ca}- \\
\left(\mathrm{H}_{2} \mathrm{PO}_{4}\right)_{2} \\
g \text { per pot }\end{array}$} & \multirow[t]{2}{*}{$\begin{array}{c}\text { Nitro- } \\
\text { gen, *) } \\
\text { g per pot }\end{array}$} & \multirow[t]{2}{*}{$\begin{array}{l}\text { Number } \\
\text { of culms } \\
\text { used }\end{array}$} & \multirow[t]{2}{*}{$\begin{array}{l}\text { Diameter } \\
\text { of } \\
\text { internodes }\end{array}$} & \multirow{2}{*}{$\begin{array}{l}\text { Culm } \\
\text { wall } \\
\text { thick- } \\
\text { ness, } \mu\end{array}$} & \multicolumn{2}{|c|}{$\begin{array}{l}\text { Thickness of } \\
\text { sclerenchym- } \\
\text { atous ring, } \mu\end{array}$} & \multirow{2}{*}{$\begin{array}{c}\text { Lignif. } \\
\text { tissue as } \\
\% \text { of total } \\
\text { area of } \\
\text { scl. ring }\end{array}$} & \multirow{2}{*}{$\begin{array}{c}\text { Thickness } \\
\text { of scleren- } \\
\text { chyma } \\
\text { cell walls, } \\
\mu\end{array}$} & \multirow[t]{2}{*}{$\begin{array}{c}\text { Number } \\
\text { of } \\
\text { vascular } \\
\text { bundles }\end{array}$} \\
\hline & & & & & & $\left.A^{* *}\right)$ & $\left.\mathrm{B}^{* *}\right)$ & & & \\
\hline \multirow[t]{6}{*}{ Oats } & 0.6 & 0.350 & $17-18$ & $33.8 \pm 0.2$ & $549 \pm 22$ & $75 \pm 3$ & $106 \pm 4$ & $93 \pm 1$ & $\{5.1 \pm 0.11\}$ & $21 \pm 0.7$ \\
\hline & 0.6 & 1.050 & $18-20$ & $30.3 \pm 0.1$ & $532 \pm 23$ & $53 \pm 2$ & $104 \pm 5$ & $98 \pm 1$ & $5,0 \pm 0.19$ & $20 \pm 0.5$ \\
\hline & 1.0 & 0.350 & $14-20$ & $36.7 \pm 0.1$ & $518 \pm 17$ & $64 \pm 2$ & $107 \pm 3$ & $94 \pm 1$ & $5.7 \pm 0.22$ & $22 \pm 0.7$ \\
\hline & 1.0 & 1.050 & $11-20$ & $37.6 \pm 0.1$ & $599 \pm 13$ & $63 \pm 1$ & $114 \pm 3$ & $91 \pm 2$ & $5.8 \pm 0.21$ & $21 \pm 0.4$ \\
\hline & 5.0 & 0.350 & 21 & $39.5 \pm 0.1$ & $647 \pm 23$ & $81 \pm 3$ & $109 \pm 3$ & $85 \pm 1$ & $5.1 \pm 0.17$ & $27 \pm 0.5$ \\
\hline & 5.0 & 1.050 & 22 & $38.6 \pm 0.1$ & $562 \pm 19$ & $68 \pm 3$ & $116 \pm 3$ & $76 \pm 3$ & $3.9 \pm 0.23$ & $27 \pm 0.3$ \\
\hline \multirow[t]{4}{*}{ Wheat } & 1.0 & 0.175 & $16-20$ & $18.7 \pm 0.1$ & $638 \pm 24$ & $61 \pm 2$ & $102 \pm 3$ & $97 \pm 0$ & $5.5 \pm 0.23$ & $22 \pm 0.6$ \\
\hline & 1.0 & 0.350 & $10-22$ & $18.2 \pm 0.1$ & $566 \pm 18$ & $63 \pm 2$ & $110 \pm 7$ & $100 \pm 1$ & $6.0 \pm 0.28$ & $21 \pm 0.5$ \\
\hline & 5.0 & 0.175 & $19-21$ & $34.2 \pm 0.0$ & $786 \pm 25$ & $85 \pm 2$ & $120 \pm 3$ & $87 \pm 5$ & $5.3 \pm 0.09$ & $31 \pm 0.4$ \\
\hline & 5.0 & 0.350 & $12-20$ & $35.4 \pm 0.0$ & $721 \pm 30$ & $81 \pm 2 \mid$ & $125 \pm 2$ & $88 \pm 2$ & $6.2 \pm 0.14$ & $32 \pm 0.3$ \\
\hline
\end{tabular}

*) as $\mathrm{NH}_{4} \mathrm{NO}_{3}$.

**) A: no vascular bundle B: vascular bundle inside sclerenchymatous ring. 
in phosphorus-deficient wheat and oat plants. This effect is very remarkable since the number of vascular bundles of cereal culms is in general very constant.

\section{EFFECT OF SOIL-pH}

Raising the $\mathrm{pH}$ of acid soils by liming often results in an improvement in the growing conditions of the plants so that a heavier crop will develop which is more liable to lodging than the unlimed one. This was found to be the case on an acid peaty soil where relatively large amounts of soil nitrogen became available upon liming (Fig.15).

RYE

Exp. tield 649.1944
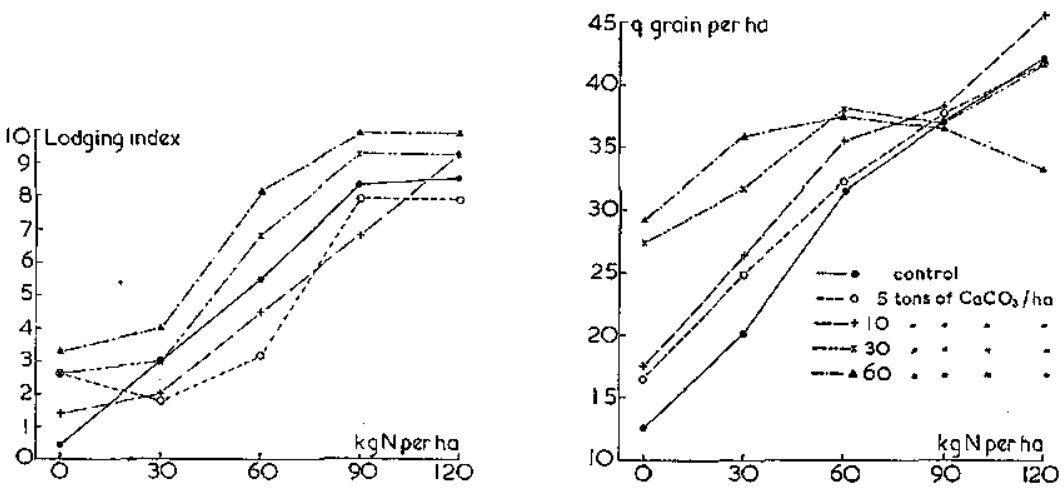

Fig. 15. Effect of liming an acid low moor peat soil and nitrogen dressings on yield and lodging of winter rye. Lodging indices determined 21 days before harvesting.

\section{EFFECT OF SOIL STRUCTURE}

The effect of soil structure on lodging of cereal crops was studied on a clay soil on which wheat was grown following two different crops, viz. Brussels sprouts leaving a poor soil structure, and red clover leaving an excellent structure. No lodging occurred on the soil with the poor structure notwithstanding the high yields which were obtained at the highest nitrogen dressings. Following the clover a moderate lodging occurred (Table XVII). From the yield data it can be seen that the latter was presumably a result of the improved nitrogen supply owing to nitrogen fixation by the clover. 
TABLE XVII

\begin{tabular}{|c|c|c|c|c|c|c|}
\hline Effect of pr & $\begin{array}{r}\text { ing crop on } \\
813,\end{array}$ & $\begin{array}{l}\text { ield *) an } \\
344 \text { (date }\end{array}$ & $\begin{array}{l}\text { odging o } \\
\text { harvesti }\end{array}$ & $\begin{array}{l}\text { Ammer w } \\
\text { Aug. 24) }\end{array}$ & Field & eriment \\
\hline \multirow{2}{*}{$\begin{array}{l}\mathrm{Kg} \text { fertiliser } \\
\mathrm{N} \text { per ha }\end{array}$} & \multicolumn{3}{|c|}{$\begin{array}{l}\text { After clover (good soil } \\
\text { structure) }\end{array}$} & \multicolumn{3}{|c|}{$\begin{array}{l}\text { After Brussels sprouts } \\
\text { (poor soil structure) }\end{array}$} \\
\hline & $\begin{array}{c}\text { Grain, } \\
\mathrm{q}^{* *} \text { ) per ha }\end{array}$ & $\begin{array}{l}\text { Straw, } \\
\text { q per ha }\end{array}$ & $\begin{array}{l}\text { Lodging } \\
\text { index, } \\
\text { Aug. } 11\end{array}$ & $\begin{array}{l}\text { Grain, } \\
\text { q per ha }\end{array}$ & $\begin{array}{l}\text { Straw, } \\
\text { q per ha }\end{array}$ & $\begin{array}{l}\text { Lodging } \\
\text { index, } \\
\text { Aug. } 11\end{array}$ \\
\hline 0 & 53.6 & 84.3 & 0 & 28.6 & 37.7 & 0 \\
\hline 40 & 56.8 & 92.3 & 1 & 38.7 & 55.4 & 0 \\
\hline 60 & 55.1 & 89.3 & 0 & 41.9 & 61.1 & \\
\hline 80 & 54.2 & 92.3 & 2 & 46.7 & 66.3 & 0 \\
\hline 100 & 53.2 & 89.5 & 3 & 47.7 & 68.2 & 0 \\
\hline 120 & 51.2 & 94.0 & $5 \frac{1}{2}$ & 49.3 & 71.4 & 0 \\
\hline 140 & 48.2 & 88.7 & $8 \frac{1}{2}$ & 49.1 & 71.5 & 0 \\
\hline
\end{tabular}

*) Average values for three plots.

**) $1 \mathrm{q}=100 \mathrm{~kg}$.

These results are in agreement with field observations. Lodged areas in unlodged fields may frequently be found to have a better soil structure as a result of which the soil-nitrogen supply to the crop has been more favourable than on the unlodged areas.

When soil structure is extremely poor, anchorage of the roots may be inadequate as a result of which the standing ability of the plants will be reduced. Nevertheless lodging does not occur on such soils because of the poor development of the tops.

\section{EFFECT OF LODGING ON YIELD}

The yield depressions resulting from lodging depend a) on the growing stage at which the crop lodged and b) on the weather conditions prevailing after lodging has taken place. When'the crop lodges before flowering i.e. before the plants have reached their full length, the culms may regain their upright position through intercalar growth of the nodes. Although such a crop will easily be flattened again, it may hold its upright position when favourable weather conditions prevail until ripening. Under these circumstances yield depressions will be of less importance than in the case of adverse weather conditions which often bring about a complete flattening. The ears may now remain partly deaf and the kernels formed will be shrivelled.

When the crop lodges some time after flowering the ears will not regain their upright position. Although in this case grain number is 
TABLE XVIII

\begin{tabular}{|c|c|c|c|c|c|c|c|}
\hline \multicolumn{8}{|c|}{ Number of plants and yield of lodged and standing areas in general fields *) } \\
\hline \multirow{2}{*}{$\begin{array}{l}\text { Field, } \\
\text { year } \\
\text { and soil }\end{array}$} & \multirow{2}{*}{ Crop } & \multirow{2}{*}{$\begin{array}{l}\text { Lodged(l) } \\
\text { or } \\
\text { erect(e) }\end{array}$} & \multirow{2}{*}{$\begin{array}{l}\text { Number } \\
\text { of culms } \\
\text { per } \mathrm{m}^{2}\end{array}$} & \multicolumn{2}{|c|}{ Yield, q per ha } & \multirow{2}{*}{$\begin{array}{c}\text { Grain } \\
\text { as } \% \text { of } \\
\text { total } \\
\text { yield }\end{array}$} & \multirow{2}{*}{$\begin{array}{c}\text { Weight } \\
\text { of } 1000 \\
\text { grains, } \\
\mathrm{g}\end{array}$} \\
\hline & & & & Grain & Straw & & \\
\hline 1, 1943, & summer wheat & $\mathrm{e}$ & 318 & 43.0 & 97.1 & 30.7 & - \\
\hline peaty & & 1 & 337 & 26.7 & 104.1 & 25.1 & - \\
\hline 2,1953 & summer wheat & e & 560 & 47.5 & 76.7 & 38.2 & 44.5 \\
\hline sandy & & l & 595 & 33.2 & 77.5 & 29.9 & 32.3 \\
\hline 3,1953 & summer wheat & e & 508 & 47.9 & 85.0 & 35.6 & 44.0 \\
\hline sandy & & 1 & 550 & 37.9 & 80.0 & 31.6 & 32.0 \\
\hline 4,1953 & summer wheat & $\mathrm{e}$ & 540 & 55.0 & 92.5 & 37.2 & 45.3 \\
\hline sandy & & 1 & 510 & 31.0 & 65.0 & 32.2 & 34.2 \\
\hline 5,1953 & oats & e & 383 & 46.3 & 57.5 & 44.4 & 32.1 \\
\hline sandy & & 1 & 418 & 39.5 & 55.0 & 41.6 & 22.3 \\
\hline 6,1953 & oats & e & - & 44.8 & 56.5 & 44.2 & 36.1 \\
\hline sandy & & 1 & 一 & 17.8 & 61.8 & 22.4 & 17,3 \\
\hline
\end{tabular}

*) Border effect eliminated.

not affected, grain weight may be considerably reduced. The degree of reduction likewise depends on weather conditions prevailing after the crop has lodged.

For estimating the reduction in grain yield resulting from lodging the following methods have been employed:

a. A comparison was made between the yields of lodged and non-lodged areas in the same plot.Table XVIII gives examples of such a comparison in crops of summer wheat and oats. Although this method provides an approximate estimation of yield depression, the values obtained may be too low because of the fact that the growing conditions for the non-lodged plants have often been less favourable than those for the lodged plants. Therefore the yield of the standing areas may be considerably lower than the yield which would have been obtained if the plants on the lodged areas had remained unlodged. This may be seen from the results obtained on experimental plots on which different amounts of fertiliser nitrogen had been applied (Fig. 3). If the severely lodged plots of Exp. 589, 1943 supplied with $180 \mathrm{~kg} \mathrm{~N}$ per ha are compared with the slightly lodged plots dressed with $140 \mathrm{~kg} \mathrm{~N}$ per ha, which yielded $4730 \mathrm{~kg}$ of rye per ha, yield reductions of 410,1000 and $1510 \mathrm{~kg}$ respectively for the triplicate plots will be found. Compared with the unlodged plots supplied with 60 and $90 \mathrm{~kg}$ of $\mathrm{N}$ per ha, however, which on an 
average yielded $3735 \mathrm{~kg}$ per ha and which may be considered as normal farmer's fields, values of $--585,+5$ and $+515 \mathrm{~kg}$ respectively will be found.

$b$. A second method which may be used when experimental fields supplied with increasing amounts of nitrogenous fertilisers are available consists of calculating the reduction in grain yield resulting from excessive nitrogen. Although this reduction may sometimes be ascribed to fertiliser interaction, it is usually due to lodging (see Fig. 3).

Under certain circumstances this method may have the same drawback as the first-mentioned, viz. when severe lodging has taken place on most plots. In that case the non-lodged plots which have to be used for calculating the yield depression will show sub-optimal yields due to nitrogen deficiency. Owing to this the calculated yield depression will be found too low. In order to overcome these difficulties the following method was introduced.

c. Parts of the crop on plots dressed excessively with nitrogen, the plants of which had generally a high tendency to lodging, were supported by ropes to keep them standing until harvest time (see Plate I). The differences in yield between the lodged and unlodged parts of the same plots were assumed to be a suitable measure of yield reduction owing to lodging. Initially the supported areas were comparatively small, viz. one meter by four, six and seven respectively (method $c_{1}$ ) so that the whole crop had to be taken for yield determinations. Table XIX shows the results of some typical experiments. It will be seen that the grain yields of the supported oat and wheat plants were often more than $50 \%$ higher than those of the lodged ones. This may be ascribed partly to a much increased carbon dioxide assimilation of the non-lodged plants and partly to a considerably higher grain-straw ratio. A typical feature of lodged plants is their shrivelled kernels which are the cause of the low hl weights.

Although the results of these experiments may explain the relatively high yields which may often be found when cereal crops are partly flattened, it is doubtable whether the values obtained give a true picture of yield reduction owing to lodging. It is very likely that small areas of standing plants within a lodged crop give higher yields than similar plants surrounded by non-lodged plants due to an increased illumination and $\mathrm{CO}_{2}$-supply.

In order to eliminate this border effect in subsequent experiments 
TABLE XIX

\begin{tabular}{|c|c|c|c|c|c|c|c|c|}
\hline \multicolumn{9}{|c|}{ Effect of lodging on yield } \\
\hline \multirow{2}{*}{$\begin{array}{l}\text { Exp., crop } \\
\text { and } \\
\text { harvest } \\
\text { date }\end{array}$} & \multirow{2}{*}{$\begin{array}{c}\mathrm{Kg} \mathrm{N} \\
\text { per } \\
\text { ha }\end{array}$} & \multicolumn{2}{|c|}{ Lodging index *) } & \multicolumn{2}{|c|}{ Yield, q per ha } & \multirow{2}{*}{$\begin{array}{l}\text { Grain as } \\
\% \text { of to- } \\
\text { tal yield }\end{array}$} & \multirow{2}{*}{$\begin{array}{c}\text { HI } \\
\text { weight, } \\
\text { lgg }\end{array}$} & \multirow{2}{*}{$\begin{array}{l}\text { Weight } \\
\text { of } 1000 \\
\text { grains, } \mathrm{g}\end{array}$} \\
\hline & & date & date & grain & straw & & & \\
\hline \multirow{9}{*}{$\begin{array}{l}607, \\
\text { summer } \\
\text { wheat, } \\
\text { Aug. } 31 \text {, } \\
1940\end{array}$} & & July 17 & Aug. 23 & & & & & \\
\hline & 50 & 1 & $2 \frac{1}{2}$ & 34.9 & 56.6 & 38.1 & 76.2 & 42.9 \\
\hline & $80(s)$ & 0 & 0 & 40.4 & 64.9 & 38.3 & 77.1 & 45.6 \\
\hline & 80 & $1 \frac{1}{2}$ & $4 \frac{1}{2}$ & 37.4 & 66.7 & 35.9 & 75.0 & 41.1 \\
\hline & $110(\mathrm{~s})$ & 0 & 0 & 52.3 & 91.6 & 36.3 & 78.0 & 47.6 \\
\hline & 110 & 6 & 8 & 36.9 & 69.8 & 34.6 & 73.9 & 40.1 \\
\hline & $140(\mathrm{~s})$ & 0 & 0 & 50.2 & 90.2 & 35.8 & 72.4 & 45.1 \\
\hline & 140 & 6 & $7 \frac{1}{2}$ & 31.9 & 69.8 & 31.7 & 71.8 & 37.3 \\
\hline & & JuIy 6 & July $31 * *)$ & & & & & \\
\hline \multirow{9}{*}{$\begin{array}{l}590, \text { oats, } \\
\text { Aug. } 26 \text {, } \\
1940\end{array}$} & 50 & $\cdot 1$ & 10 & 38.7 & 62.1 & 38.4 & 48.2 & 32.0 \\
\hline & $80(s)$ & 0 & 0 & 51.2 & 70.9 & 41.9 & 52.0 & 36.2 \\
\hline & 80 & $1 \frac{1}{2}$ & 10 & 40.5 & 64.1 & 38.7 & 46.7 & 30.0 \\
\hline & $110(\mathrm{~s})$ & 0 & 0 & 61.2 & 90.3 & 40.4 & 50.8 & 33.6 \\
\hline & 110 & 7 & 10 & 39.6 & 71.4 & 35.7 & 45.6 & 29.3 \\
\hline & $140(s)$ & 0 & 0 & 65.9 & 90.0 & 42.3 & 51.1 & 33.7 \\
\hline & 140 & 8 & 10 & 42.5 & 73.9 & 36.5 & 43.8 & 29.8 \\
\hline & $170(\mathrm{~s})$ & 0 & 0 & 60.3 & 88.3 & 40.6 & 50.5 & 33.9 \\
\hline & 170 & $6 \frac{1}{2}$ & 10 & 42.2 & 77.2 & 35.3 & 44.4 & 28.4 \\
\hline
\end{tabular}

*) $0=$ standing, $10=$ completely lodged, $\mathrm{s}=$ supported.

**) July 31 the whole field was completely flattened except the supported plots which were standing.

TABLE XX

\begin{tabular}{|l|l|l|l|l|l|l|}
\hline \multicolumn{6}{|c|}{ Effect of lodging on yield. Winter rye. Exp. 596, 1942 } \\
\hline $\begin{array}{l}\text { Kg N } \\
\text { per ha }\end{array}$ & \multicolumn{2}{|c|}{ Lodging index, date ${ }^{*}$ ) } & \multicolumn{2}{|c|}{ Yield, q per ha } & $\begin{array}{c}\text { Grain as } \\
\% \text { of total } \\
\text { yield }\end{array}$ \\
\hline & & & grain & straw & \\
$30(\mathrm{~s}) *)$ & 0 & 0 & 0 & 32.9 & 69.3 & 32.2 \\
30 & 0 & 0 & $1 \frac{1}{2}$ & $31.5 \pm 1.3$ & $61.6 \pm 1.2$ & 33.8 \\
$60(\mathrm{~s})$ & 0 & 0 & 2 & 42.2 & 88.6 & 32.3 \\
60 & 2 & 3 & $6 \frac{1}{2}$ & $33.3 \pm 0.3$ & $70.5 \pm 2.1$ & 32.1 \\
$90(\mathrm{~s})$ & 0 & 0 & 0 & 41.2 & 82.5 & 33.3 \\
90 & $4 \frac{1}{2}$ & $5 \frac{1}{2}$ & 7 & $28.6 \pm 1.2$ & $69.6 \pm 2.0$ & 29.1 \\
$120(\mathrm{~s})$ & 0 & 0 & 0 & 36.4 & 77.5 & 32.0 \\
120 & $7 \frac{1}{20}$ & $7 \frac{1}{2}$ & 9 & $31.3 \pm 0.6$ & $73.9 \pm 1.2$ & 29.8 \\
$150(\mathrm{~s})$ & 0 & 0 & 0 & 35.8 & 80.3 & 30.8 \\
150 & $8 \frac{1}{2}$ & 8 & $9 \frac{1}{2}$ & $23.3 \pm 2.5$ & $68.3 \pm 4.6$ & 25.5 \\
\hline
\end{tabular}

*) $\mathrm{s}=$ supported plots (single values).

**) Date of harvest August 19. 
TABLE XXI

\begin{tabular}{|c|c|c|c|c|c|c|c|c|c|}
\hline \multicolumn{10}{|c|}{ Effect of lodging on yield } \\
\hline \multicolumn{5}{|c|}{ Experiment 612,1941 (winter rye) } & \multicolumn{5}{|c|}{ Experiment 658, 1942 (summer wheat) } \\
\hline $\begin{array}{l}\text { Lodging } \\
\text { index, } \\
\text { June } 21\end{array}$ & $\begin{array}{c}\mathrm{Kg} \mathrm{N} \\
\text { per } \\
\mathrm{ha}\end{array}$ & $\begin{array}{l}\text { Grain } \\
\text { yield, } \\
\text { q per ha }\end{array}$ & $\begin{array}{c}\text { Grain } \\
\text { yield of } \\
\text { unlodged } \\
\text { plots, *) } \\
\text { q per ha }\end{array}$ & $\begin{array}{c}\text { Reduction } \\
\text { in grain } \\
\text { yield, } \\
\text { q per ha }\end{array}$ & $\begin{array}{l}\text { Lodging } \\
\text { index, } \\
\text { July } 14\end{array}$ & $\begin{array}{c}\mathrm{Kg} \mathrm{N} \\
\text { per } \\
\text { ha }\end{array}$ & $\begin{array}{l}\text { Grain } \\
\text { yield, } \\
\text { q per ha }\end{array}$ & $\begin{array}{c}\text { Grain } \\
\text { yield of } \\
\text { unlodged } \\
\text { plots, }{ }^{*} \text { ) } \\
\text { q per ha }\end{array}$ & $\left\{\begin{array}{c}\text { Reduction } \\
\text { in grain } \\
\text { yield, } \\
\text { q per ha }\end{array}\right.$ \\
\hline \multirow[t]{7}{*}{4} & $\overline{110}$ & 31.3 & $\left.36.5(7)^{* *}\right)$ & +5.2 & 4 & 80 & 30.2 & $\left.28.2(17)^{* *}\right)$ & -2.0 \\
\hline & 110 & 34.2 & $36.5(7)$ & +2.3 & & 80 & 29.7 & $28.2(17)$ & -1.5 \\
\hline & 140 & 43.2 & $38.7(5)$ & -4.5 & & 120 & 26.0 & $27.7(14)$ & +1.7 \\
\hline & 140 & 36.9 & $38.7(5)$ & +1.8 & & & & & \\
\hline & 180 & 38.3 & $36.7(6)$ & -1.6 & 5 & 160 & 29.2 & $26.7(11)$ & -2.5 \\
\hline & 180 & 40.1 & $36.7(6)$ & -3.4 & & 160 & 26.5 & $26.7(11)$ & +0.2 \\
\hline & 180 & 41.7 & $36.7(6)$ & -5.0 & & 160 & 28.5 & $26.7(11)$ & -1.8 \\
\hline \multirow[t]{4}{*}{5} & 85 & 37.9 & $35.8(10)$ & -2.1 & 6 & 40 & 31.0 & $24.4(15)$ & -6.6 \\
\hline & 140 & 34.0 & $38.7(5)$ & +4.7 & & & & & \\
\hline & 180 & 33.7 & $36.7(6)$ & +3.0 & 7 & 160 & 26.7 & $26.7(11)$ & 0 \\
\hline & & & & & & 160 & 27.8 & $26.7(11)$ & -1.1 \\
\hline \multirow[t]{4}{*}{6} & 85 & 32.2 & $35.8(10)$ & +3.6 & & 160 & 28.4 & $26.7(11)$ & -1.7 \\
\hline & 140 & 38.6 & $38.7(5)$ & +0.1 & & & & & \\
\hline & 140 & 35.8 & $38.7(5)$ & +2.9 & 8 & 120 & 21.3 & $27.7(14)$ & +6.4 \\
\hline & & & & & & 160 & 25.3 & $26.7(11)$ & +1.4 \\
\hline \multirow[t]{2}{*}{$6 \frac{1}{2}$} & 140 & 33.9 & $38.7(5)$ & +4.8 & & & & & \\
\hline & & & & & 9 & 80 & 24.8 & $28.2(17)$ & +3.4 \\
\hline \multirow[t]{3}{*}{7} & 110 & 32.5 & $36.5(7)$ & +4.0 & & 120 & 20.7 & $27.7(14)$ & +7.0 \\
\hline & 180 & 35.9 & $36.7(6)$ & +0.8 & & 120 & 18.9 & $27.7(14)$ & +8.8 \\
\hline & & & & & & 120 & 26.5 & $27.7(14)$ & +1.2 \\
\hline \multirow[t]{2}{*}{$7 \frac{1}{2}$} & 110 & 31.3 & $36.5(7)$ & +5.2 & & 160 & 22,7 & $26.7(11)$ & +4.0 \\
\hline & 140 & 28.5 & $38.7(5)$ & +10.2 & & 160 & 23.6 & $26.7(11)$ & +3.1 \\
\hline \multirow[t]{2}{*}{8} & 110 & 34.7 & $36.5(7)$ & +1.8 & 10 & 120 & 19.7 & $27.7(14)$ & +8.0 \\
\hline & 180 & 37.4 & $36.7(6)$ & -0.7 & & & & & \\
\hline
\end{tabular}

*) Also includes the yields of plots with lodging index 3 or lower.

**) Number of plots from which the average values were calculated.

the supported plots were taken much larger so that the border plants could be discarded (method $c_{2}$ ).

The results of an experiment of this type are given in Table XX.

d. A fourth method of calculating the yield depressions owing to lodging, has been used in those cases where a large variation in lodging occurred resulting from different rates of sowing, different spacings, etc. Yield depressions of plots having a lodging index of 4 and higher were calculated by subtracting their yield values from average yield values of unlodged plots which had been dressed with 
TABLE XXII

\begin{tabular}{|c|c|c|c|c|c|c|c|c|c|c|c|c|c|}
\hline \multicolumn{14}{|c|}{ Effect of lodging on loss of grain yield } \\
\hline \multirow{2}{*}{$\begin{array}{l}\text { Exp. } \\
\text { and } \\
\text { year }\end{array}$} & \multicolumn{3}{|c|}{$\begin{array}{l}\text { Mean lodging } \\
\text { index }\end{array}$} & \multicolumn{2}{|c|}{ Reduction } & \multirow{2}{*}{ 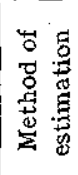 } & \multirow{2}{*}{$\begin{array}{c}\text { Exp. and } \\
\text { year }\end{array}$} & \multicolumn{3}{|c|}{$\begin{array}{l}\text { Mean lodging } \\
\text { index }\end{array}$} & \multicolumn{2}{|l|}{ Reduction } & \multirow{2}{*}{ 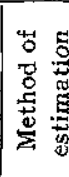 } \\
\hline & 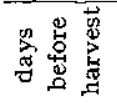 & 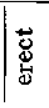 & $\begin{array}{l}0 \\
0 \\
00 \\
0 \\
0\end{array}$ & q per ha & $\%$ & & & 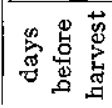 & 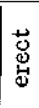 & $\mid \begin{array}{l}8 \\
8 \\
8 \\
0 \\
0\end{array}$ & q per ha & $\%$ & \\
\hline \multicolumn{2}{|l|}{ Winter rye } & & & & & & \multicolumn{2}{|l|}{ Summer reheat } & & & & & \\
\hline $589, ' 41$ & 51 & $1 \frac{1}{2}$ & $4 \frac{1}{2}$ & $7.8 \pm 7.1$ & 16.3 & B & $813, ' 44$ & 37 & $\frac{1}{2}$ & 4 & $4.9 \pm 1.4$ & 8.7 & B \\
\hline '41 & 51 & 0 & $4 \frac{1}{2}$ & 8.4 & 17.3 & $\mathrm{C}_{1}$ & $' 44$ & 37 & 0 & 4 & $4.2 \pm 4.5$ & 7.6 & $\mathrm{C}_{8}$ \\
\hline '43 & 58 & 2 & $5 \frac{1}{2}$ & 8.4 & 19.4 & $A$ & Gf*) $1,{ }^{\prime} 43$ & - & 0 & 10 & $16.3 \pm 4.4$ & 37.9 & $A$ \\
\hline$' 43$ & 58 & $1 \frac{1}{2}$ & $4 \frac{1}{2}$ & $9.7 \pm 3.6$ & 20.5 & B & Gf $2,{ }^{\prime} 53$ & 一 & 0 & 10 & $14.3 \pm 5.3$ & 30.1 & A \\
\hline$' 47$ & 20 & $6 \frac{1}{2}$ & $8 \frac{1}{2}$ & $4.7 \pm 0.5$ & 13.3 & B & $3, ' 53$ & - & 0 & 10 & $10.0 \pm 3.2$ & 21.3 & A \\
\hline $596, ' 42$ & 61 & 0 & 7 & $10.0 \pm 5.5$ & 26.5 & $\mathrm{C}_{2}$ & Gf $\quad 4, ' 53$ & 一 & 0 & 10 & $24.0 \pm 6.0$ & 43.6 & A \\
\hline $612, ' 41$ & 45 & 1 & 8 & $4.2 \pm 2.1$ & 11.3 & $D$ & Oats & & & & & & \\
\hline $614, ' 41$ & 54 & $2 \frac{1}{2}$ & $4 \frac{1}{2}$ & $2.6 \pm 2.1$ & 6.1 & $\mathrm{C}_{2}$ & $590, ' 40$ & 51 & 1 & 6 & $-1.3 \pm 2.0$ & -3.1 & B \\
\hline '41 & 54 & $2 \frac{1}{2}$ & 7 & $8.1 \pm 4.9$ & 18.9 & $\mathrm{C}_{2}$ & '40 & 51 & 0 & 6 & $18.9 \pm 2.1$ & 31.3 & $\mathrm{C}_{1}$ \\
\hline $649, ' 49$ & 63 & 0 & 8 & $3.8 \pm 4.3$ & 8.6 & $A$ & $595, ' 41$ & 15 & 2 & 6 & $-5.0 \pm 2.2$ & -13.5 & B \\
\hline '49 & 63 & $2 \frac{1}{8}$ & $8 \frac{1}{2}$ & $6.7 \pm 0.9$ & 15.8 & B & '41 & 15 & 0 & 6 & $6.7 \pm 1.7$ & 13.8 & $\mathrm{C}_{1}$ \\
\hline \multicolumn{2}{|c|}{ Summey rye } & & & & & & $598, ' 40$ & 22 & 3 & 4 & $-3.8 \pm 1.8$ & -8.8 & $\mathrm{~B}$ \\
\hline $612, ' 41$ & 57 & 1 & 9 & $0.3 \pm 0.4$ & 1.0 & $\mathrm{D}$ & '40 & 22 & 0 & 5 & $-1.4 \pm 4.7$ & -3.0 & $\mathrm{C}_{1}$ \\
\hline \multicolumn{2}{|c|}{ Winter wheat } & & & & & & $600, ' 40$ & 22 & 2 & 9 & $-5.6 \pm 1.0$ & -11.7 & A \\
\hline $650, ' 44$ & 32 & 2 & 7 & 9.4 & 25.4 & A & 40 & 22 & 0 & 5 & $4.5 \pm 1.3$ & 8.0 & $C_{1}$ \\
\hline$' 44$ & 32 & $\frac{1}{2}$ & 4 & $9.2 \pm 1.9$ & 20.7 & B & $611, ' 41$ & 21 & 4 & $8 \frac{1}{2}$ & $-5.6 \pm 1.1$ & -14.7 & B \\
\hline $665, ' 43$ & 50 & 0 & 10 & 9.8 & 25.6 & A & $1413, * *) \times 53$ & 50 & 0 & 10 & $13.1 \pm 2.0$ & 29.2 & B \\
\hline \multicolumn{2}{|c|}{ Summer wheat } & & & & & & Gf $5, ' 53$ & - & 0 & 10 & $6.8 \pm 4.1$ & 14.7 & A \\
\hline $588, ' 41$ & 3 & 0 & 5 & $3.5 \pm 1.9$ & 8.1 & $\mathrm{C}_{2}$ & Gf 6, ' 53 & 一 & 0 & 10 & $27.0 \pm 7.0$ & 60.3 & A \\
\hline $591, ' 40$ & 29 & 0 & 3 & $1.7 \pm 0.7$ & 3.7 & $\mathrm{C}_{1}$ & \multicolumn{2}{|l|}{ Winter barley } & & & & & \\
\hline $596, ' 40$ & 42 & 0 & $4 \frac{1}{2}$ & $4.3 \pm 1.2$ & 16.7 & $\mathrm{C}_{\mathrm{I}}$ & $759, ' 43$ & 40 & 2 & 7 & $-0.3 \pm 2.0$ & -0.6 & B \\
\hline $607, ' 40$ & 45 & $1 \frac{1}{2}$ & 6 & $3.0 \pm 1.5$ & 8.0 & B & ' 43 & 40 & 0 & 7 & $2.2 \pm 2.3$ & 4.4 & $\mathrm{C}_{2}$ \\
\hline '40 & 45 & 0 & 6 & $16.9 \pm 1.9$ & 32.9 & $\mathrm{C}_{1}$ & \multicolumn{2}{|c|}{ Summer burley } & & & & & \\
\hline $658, ' 42$ & 51 & $2 \frac{1}{8}$ & 5 & $3.7 \pm 1.6$ & 13.0 & $\mathrm{~B}$ & $599, ' 40$ & 42 & 2 & 8 & $3.4 \pm 1.1$ & 7.6 & $\mathrm{~B}$ \\
\hline 42 & 51 & $\frac{1}{2}$ & 9 & $5.6 \pm 1.3$ & 20.3 & D & '40 & 42 & 0 & 8 & $11.8 \pm 1.3$ & 22.3 & $\mathrm{C}_{1}$ \\
\hline
\end{tabular}

*) $\mathrm{Gf}=$ general field.

**) Exp. field of J. P r u m m e l of this station.

equal amounts of nitrogen (see Table XXI). From these data it will be seen that the yields of slightly lodged crops were often higher than those of standing crops. When, however, shortly after flowering lodging indices of 7 or higher were found, depressions in grain yield varying from 10 to $30 \%$ were common.

In order to determine the average losses in grain yield for various crops the results of all experimental fields on the subject available have been brought together in Table XXII. It will be seen that a large 
variation exists in the calculated values. This is partly due to the different methods of estimation used and partly to the difference in weather conditions prevailing after the crop had fallen.

\section{The cause of yield reduction of lodged plants}

Reduced carbon dioxide assimilation resulting from inadequate illumination of the green tissues is apparently the main cause of the reduced weight of lodged plants. The fact that grain formation is affected much more seriously than straw production is in accordance with this conception. The grains are formed during a relatively short period of time in which lodging frequently occurs. Straw production, however, takes place over the entire growing period.

Whether the reduced length of the highest culm internodes which is a common feature of early lodged plants may adversely affect grain formation is unknown. According to $\mathrm{B}$ oon stra${ }^{5}$ ) the assimilation of the first internode contributes approximately 10 per cent towards grain formation.

In addition to the reduced carbon-dioxide assimilation, secondary factors may play a part in reducing the grain yield of lodged plants. When the plants fall before flowering, pollination may be affected as a result of which the ears remain partly deaf.

Lodged wheat plants may sometimes be heavily attacked by the semi-parasitic fungus Septoria nodorum which, beginning from the top, brings about necrosis and grey-brown discoloration of the chaffs. As carbon dioxide assimilation of the latter plays an important part in the grain formation (see Boonstra ${ }^{5}$ )), it will easily be seen that an early dying of these tissues appreciably effects the grain yield.

\section{DISCUSSION}

Lodging of cereal crops results from the combination of adverse weather conditions and an inadequate standing ability of the plants. The latter may be due to relatively weak lower internodes of the culm or to an inadequate anchorage of the plants in the soil in proportion to the weight of the upper parts of the plants. The heavier the weight of the leaves, the culm and the ear and the greater the distance of their centre of gravity to the base of the plants, the stronger should be the resistance to bending of the lower internodes 
and the stronger the anchorage of the plants in the soil. This means that tendency to lodging is not a question of one particular plant property, but results from the lack of proportionality between sturdiness of the basal parts of the plants and the weight of the upper parts.

Although uprooting of plants without any bending of the lower internodes of the culm was found in a few cases to be the cause of lodging of crops dressed excessively with nitrogen, in by far the majority of the cases studied by the author the lodged plants had bent and sometimes broken lower internodes. The fact that plants dressed with excessive amounts of nitrogen were found to have a less strongly developed root system than plants with a more moderate nitrogen supply suggests that a combination of bending of the lower internodes and bending or breaking of the roots may occur rather frequently in lodged crops. It is difficult to decide, however, whether inadequate resistance of the culm base or of the roots will be the primary cause of the lodging.

From the results of the present investigation it has become clear that growing conditions during the period of elongation of the lower internodes of the cereal plants are of predominating importance in determining the tendency to lodging of the full-grown crop. These growing conditions include soil fertility, particularly available nitrogen, water supply to the plants and air humidity, and light conditions. The combination of favourable moisture conditions, relatively high temperature, cloudiness, and excessive supply of nitrogen during this part of the growing period gives rise to a very rapid growth of the young cereal plant which results in the formation of long and weak lower internodes. This is still further promoted by a dense stand of the crop. Although length of lower internodes as such has little value as an index for standing ability of the plants, it may be considered more or less as an indicator of type of growth during the early stages of the growing period. The long lower internodes often resulting from favourable growing conditions are sometimes correlated with a small culm diameter and a poor culm wall thickness. More frequently the area of lignified tissue of the sclerenchyma zone, the thickness of the lignified tissues and particularly the wall thickness of the sclerenchyma cells are reduced, whereas the development of the upper parts of the plants is more luxuriant. This gives rise to a high tendency to lodging in such a 
crop. A mere wettening of the foliage and of the ears by a light rain may give rise to the flattening of the crop.

As to the influence of the various growing conditions on plant characters related to standing capacity, it has been shown that the effect of nitrogen on length and sturdiness of lower internodes is an indirect one, resulting from etiolation of the basal parts of the stem owing to the much increased leaf canopy. Apparently the same is true of water supply, since no particular effect on length of lower internodes was observed in pot experiments with widely differing moisture contents of the soil. High temperature has presumably both a direct and an indirect effect on length of lower internodes. This is concluded from the fact that in 1949 when the temperature in the spring was relatively high, exceptionally long lower internodes were formed both in the absence and presence of high nitrogen dressings. In the latter case, however, the lengths were greater than in the absence of applied nitrogen.

In addition to the indirect influence of available nitrogen on lodging resistance of cereal plants, a direct effect was found to exist viz. an adverse effect of nitrogen nutrition on the thickness of lignified tissues and particularly on the wall thickness of the sclerenchyma cells of the lower internodes of the culm. Furthermore nitrogen dressings substantially promote the development of the higher parts of the plants whilst at excessive levels a notable reduction in root development may often be observed. The latter is in agreement with the results obtained by $\mathrm{Turne} \mathrm{r}{ }^{36}$ ) who grew barley and maize in nutrient solutions at different nitrate concentrations and with those of $\mathrm{Goedewa} g$ e $\mathrm{n}$ who carried out pot experiments with wheat ${ }^{13}$ ) and field experiments on permanent grassland ${ }^{16}$ ).

The nitrogen-carbohydrate antagonism, as observed in the reduced lignification of cereal culms with increased nitrogen supply, is of general importance in plant physiology. The reduced root formation at high nitrogen levels presumably depends on the same principle. In sugar beet and potato its existence was shown by the author in field experiments with varying nitrogen dressings. In some varieties of potato the formation of tubers was largely suppressed by excessive amounts of nitrogen. At the expense of these storage tissues large amounts of protein-rich leaves were formed.

Potassium-deficient cereal plants, in addition to having a slack

Plant and Soil V 
appearance, possess brittle culms so that breakages occur more frequently than in the case of plants supplied with adequate amounts of potassium. As a result of this, potassium dressings will often give the impression of strengthening the plants. Although in general this was found to be true, in a number of cases plants dressed adequately with potassium lodged more severely than those with symptoms of $\mathrm{K}$-deficiency. Presumably this was due to the poor development of the deficient plants in comparison with the heavy and dense crop as occurred with the full dressing. No indications were obtained that excessive amounts of potassium may exert any strengthening effect on the standing ability of cereal plants.

Length and diameter of culm internodes and in some cases culm wall thickness were found to be clearly reduced in potassiumdeficient cereal plants. This will result in a weakening of the culms in the case of potassium deficiency, a conclusion which is in agreement with the results obtained by $\mathrm{T} \mathrm{u} \mathrm{b} \mathrm{b} \mathrm{s}{ }^{35}$ ) with barley. Thickness of lignified cell walls of the sclerenchymatous ring as determined microscopically was slightly reduced in potassium-deficient culms. Chemically however, higher values for lignin were found in the K-deficient culms. It is not known whether in the latter plants "lignin" includes some other compound which is not present in the plants dressed adequately with potassium or that the increased lignin content is simply due to a decrease of other compounds in the K-deficient plants.

Phosphorus-deficient oat and wheat plants were found to have a thinner culm wall, an observation which is in agreement with the results of $\mathrm{K}$ is s el ${ }^{21}$ ). Thickness of the sclerenchymatous tissue was reduced in phosphorus-deficient wheat but not in oats. In spite of the decreased strength of phosphorus-deficient plants, liability to lodging was found to be increased by phosphate dressings on some experimental fields apparently as a result of the heavier and denser crop in the case of full dressing in comparison with the phosphorusdeficient crop.

Lodging frequently brings about a serious depression in the yield of cereal crops. In addition to a reduced quantity of grain, quality is often badly affected. The size of the yield depression depends to a large extent on the weather conditions prevailing after the crop had fallen. This presumably is the main reason for the large variation in grain losses found in the present investigation (Table XXII). Under 
very wet conditions as was the case in 1953 , losses of 30 per cent may frequently be found. Losses of 10-20 per cent are more common, however, whilst under favourable weather conditions values below 10 per cent will be found.

\section{SUMMARY}

The effect of nitrogen, phosphorus and potassium nutrition on lodging and yield of cereals was studied on experimental plots laid out on different soils during the years 1940 to 1949 .

It was shown that favourable growing conditions prevailing during the first part of the growing period of the plants, particularly during the period of elongation of the lower culm internodes, give rise to a crop with a high tendency to lodging. These growing conditions include supply of nutrient elements, particularly of nitrogen, water supply and temperature. Ample nitrogen in combination with an optimal supply of other nutrients, an optimal water supply and a relatively high temperature at this stage will almost invariably produce a crop with a high liability to lodging. A poor illumination of the stems such as may result from shading or from a high density of the crop due to a high rate of seeding or a high proportion of weed will also decrease the standing ability of the plants. If during the period of elongation of the lower culm internodes, however, the plants suffer from a shortage of water, culms with a high standing ability will be formed.

Cereal crops with a high tendency to lodging may remain erect in the absence of adverse weather conditions during the period between ear emergence and ripening. Frequently, however, even a light rain will be sufficient to bring down such a crop. Heavy rain storms may flatten a crop which under normal climatic conditions would have maintained its upright position.

In by far the majority of cases studied by the author lodged cereal plants had bent and sometimes broken basal internodes. A combination of bending of the lower internodes and bending or breaking of the roots presumably may frequently occur in lodged crops.

An comprehensive study was made of the effect of nitrogen dressings on" a number of plant properties related to the standing ability of cereal plants. Plants supplied amply with nitrogen, which in general have a high tendency to lodging, were found to have longer lower culm internodes than those grown on the same field with a low or moderate nitrogen supply. The upper two internodes of the former plants were often considerably shorter, particularly when lodging had taken place before the plants had reached their full height. The number of measurable internodes tends to increase with increased nitrogen supply.

With an increased rate of nitrogen supply, the diameter of the upper culm internodes was often found to be considerably increased; the lower internodes, however, had equal or smaller diameters. 
In a number of cases the culm wall thickness of lodged plants was found to be considerably smaller than that of non-lodged plants. In some other cases, however, no difference or even the reverse was found.

The thickness of the sclerenchymatous ring in a number of cases tended to decrease with increased nitrogen supply. Thickness of sclerenchyma cell walls and area of lignified tissue in the sclerenchyma zone were found to be appreciably reduced by ample nitrogen. The number of vascular bundles was unaffected by nitrogen nutrition but ignification of these bundles and of the outer layers of parenchyma was reduced by large dressings with nitrogenous fertilisers.

Weight per $\mathrm{cm}$ of basal culm length was frequently found to be lower in plants treated with ample nitrogen.

The development of the root system was likewise found to be clearly affected by nitrogen dressings. Lodged plants supplied with excessive amounts of nitrogen had a less sturdy root system with less heavily lignified roots.

The results of the latter experiments have shown that weakness of the basal parts of a cereal plant may be brought about by the poor development of various plant characters. Since tendency to lodging depends on a disproportionality between the weight of the aerial parts of the plant and the resistance to bending and breaking of the basal culm internodes and the roots, it can be concluded that a high liability to lodging may, in different cases, be due to different causes.

In pot experiments with different degrees of illumination and in field experiments with different rates of seeding and spacing it was found that the unfavourable effect of excessive amounts of nitrogen on the strength of the basal parts of cereal culms has to be attributed partly to an indirect shading effect and partly to a direct nutritional effect. Elongation of the lower internodes depends entirely on the shading effect whilst reduction of culm diameter, of culm wall thickness and of lignification may be brought about by shading as well as by a direct nitrogen effect.

Although the straw of potassium-deficient cereal plants is more brittle than that of plants supplied with adequate amounts of potassium, more severe lodging in the latter was sometimes observed. This was presumably due to the heavier and denser crop in the case of fully dressed plants. No effect of excessive amounts of potassium on strength of culms was observed.

$K$-deficient plants in general had shorter and thinner internodes than plants supplied normally with potassium. The thickness of the sclerenchyma cell walls tended to be slightly reduced in the case of potassium deficiency.

Phosphorus-deficient plants lodged less severely than those dressed amply with phosphate, apparently due to a poorer development. The number of vascular bundles was found to be reduced in phosphorus-deficient oat and wheat plants.

Liming an acid peaty soil was found to increase the tendency to lodging of a cereal crop growing on this soil, due to the improved nitrogen supply of the plants. 
A poor soil structure was found to give no increased liability to lodging of cereal plants.

For estimating the reduction in grain yield due to lodging different methods have been employed, viz. a) comparison of the yields of lodged and non-lodged areas in the same field, $b$ ) calculation of the reduction in grain yield at high nitrogen dressings on fertiliser experimental fields, c) comparison of the yields of lodged and non-lodged (supported) parts of plots dressed with high amounts of fertiliser nitrogen, d) comparison of the yields of cereal plots with a different lodging index due to a different rate of sowing and a different spacing of the plants.

The losses in yield of grain due to lodging varied from 0 to 60 per cent. In some cases even negative values have been found. This large variation was due partly to the different methods of estimation and partly to the difference in weather conditions prevailing after the crop had fallen.

\section{ACKNOWLEDGEMENT}

The author is much indebted to Dr L. Ley to n, Department of Forestry, University of Oxford, for reading and improving the text of this paper.

Received April 6, 1954.

\section{REFERENCES}

1) Albrecht, K., Untersuchungen über Korrelationen im Aufbau des Weizenhalmes, welche für die Lagerfestigkeit des Getreides von Bedeutung sind. Landwirtsch. Jahrb. 37, 617-672 (1908).

2) A t kin s, I. M., Relation of certain plant characters to strength of straw and lodging in winter wheat. J. Agr. Research 56, 99-120 (1938).

3) A t k i n s, I. M., Inheritance of weight per unit length of culm and other characters in Kanred $x$ Coppei wheat. J. Agr. Research 76, 53-72 (1948).

4) B o c k m a n n, H., Der Einflusz der Stickstoffdüngung auf die Halmbruchkrankheit (Lagerfuszkrankheit) des Weizens. Phytopathol. Z. 19, 383-388 (1952).

5) B o o n t $x$ a, A. E. H. R., Der Einflusz der verschiedenen assimilierenden Teile auf den Samenertrag von Weizen. Z. Zücht. Reihe A Pflanzenzücht. 21, 115-147 (1936).

6) B r a d y, J., Some factors influencing lodging in cereals. J. Agr. Sci, 24, 209-232 (1934).

7) Bra un s, E. B., The chemistry of lignin. Academic Press, New York (1952).

8) Caffrey, M. and Carro11, P. T., Lodging in oats. J. Dep. Agr. 35, 25-38 (1938).

9) Cl a r k, E. R. and W i 1 s o n, H. K., Lodging in small grains. J. Am. Soc. Agrỏn. 25, 561-572 (1933).

10) Davis, L. L. and Stant on, T. R., Studies on the breaking strength of straw of oat varieties at Aberdeen, Idaho. J. Am. Soc. Agron. 24, 290-300 (1932).

11) Droogleever Fortuyn-van Leyden, C. E., Mededeel. Dep. Landb. Econ. Zaken Paramaribo Suriname no. 5 (1946).

12) G a r ber, R. J. and O ls e n, P. J., A study of the relation of some morphological characters to lodging in cereals. J. Am. Soc. Agron. 11, 173-186 (1919).

13) Goed e w a a ge n, M. A. J., Het wortelstelsel der landbouwgewassen. Algemene Landsdrukkerij, 's-Gravenhage (1942).

14) Goedew a a gen, M. A. J., De methoden, die aan het Landbouwproefstation en Bodemkundig Instituut T.N.O. te Groningen bij het wortelonderzoek op bouwen grasland in gebruik zijn. Groningen (1948). 
15) Goed ew a a gen, M. A. J., Een en ander over de methodiek van het wortelonderzoek.op bouw- en grasland. Maandblad Landbouwvoorl. 6, 194-200 (1949).

16) Goed e w a a e n, M. A. J., Wortelontwikkeling en droogteschade in het gewas in het bijzonder op grasland. Verslagen Technische bijeenkomsten Hydrologische Commissie T.N.O. 's-Gravenhage 1-6, 206-222 (1952).

17) G o s s, M. J. and P hilli p s, M., Studies on the quantitative estimation of lignin. J. Assoc. Offic. Agr. Chemists 19, 341-350 (1936).

18) H a Ili d a y, D. J., Nitrogen for cereals. Jealott's Hill Research Sta. Bull. 6, pp. 38 (1948).

19) H a milton, D. G., Culm, crown and root development in oats as related to lodging. Sci. Agr. 31, 286-315 (1951).

20) H a n l e y, F., Lodging in cereals. J. Mineral Agr. 48, 212-216 (1942).

21) Kisse1, J., Der Bau des Gramineenhalmes unter dem Einflusz verschiedener Düngung. Ber. Oberhessischen Ges. Natur u. Heilk., Giessen Naturw. Abt. 1, 43-85 (1904-1906).

22) $\mathrm{K} \circ \mathrm{c} \mathrm{h}$, L., Abnorme Aenderungen wachsender Pflanzenorgane durch Beschattung. Botanischer Jahresber, 1, 283-284 (1873).

23) $\mathrm{K} \mathbf{r}$ a $\mathrm{n} \mathrm{t} z$, B. A. and $\mathrm{Ch}$ a $\mathrm{ndl} \mathrm{e} \mathrm{r}$, W. V., Lodging, leaf composition, and yield of corn as influenced by heavy applications of nitrogen and potash. Agron. J. 48, $547-552$ (1951).

24) K r a 1 s, C., Die Lagerung der Getreide. Stuttgart (1908).

25) M ol de n h a w er, K. V., Die Gefässbundelzahl und ihre Bedeutung für die Lagerung des Getreides. Z. Landw. Versuchsw. Deut. Oesterr. 17, 886-891 (1914).

26) Perciva l, J., The wheat plant. Duckworth and Co., London. 463 pp. (1921).

27) Phillips, M., D avids on, J. and We ih e, H. D., Studies of lignin in wheat straw with reference to lodging. J. Agr. Research 43, 619-626 (1931).

28) P u r vis, O. N., The effect of potassium salts on the anatomy of Dactylis glomerata. J. Agr. Sci. 9, 338-365 (1919).

29) R a mi a h, K. and $\mathrm{D} \mathrm{h}$ a r m a li.n g a $\mathrm{m}$, S., Lodging of straw and its inheritance in rice (Oryza sativa). Indian J. Agr. Sci. \$, 880-894 (1934).

30) Rivera, cited by We 1 t on (38).

31) S a c h s, J., Handbuch der Experimental Physiologie der Pflanzen, Leipzig (1865).

32) S a I m o n, S. C., An instrument for determining the breaking strength of straw and a preliminary report on the relation between breaking strength and lodging. J. Agr. Research 43, 73-82 (1931).

33) S c hulz e, B., Wurzelatlas. Verlagsbuchhandlung Paul Parey, Berlin (191 I).

34) S w i e c i c k i, B., Die Bedeutung der Kieselsäure als Bestandteil der Pflanzen und ihre Beziehung zum Lagern des Getreides. Ber. Physiol. Lab. Versuchsanstalt Univ. Halle 14, 66-108 (1900).

35) T u b b s, F. R., Physiological studies in plant nutrition. II The effect of manural deficiency upon the mechanical strength of barley straw. Ann. Botany 44, 147-160 (1930).

36) Turner, T. W., Studies of the mechanism of the physiological effects of certain mineral salts in altering the ratio of top growth to root growth in seed plants. Am. J. Botany, 9, 415-445 (1922).

37) V a n $D \circ b$ b e n, W. H., Enkele metingen aan het stro van drie zaaitijdenproeven met zomergraanrassen benevens gegevens betreffende de oogstcompositie. Verslag Centr. Inst. Landbouwk. Onderzoek 1950, 79-87 (1951).

38) We 1 t o n, F. A., Lodging in oats and wheat. Botan. Gaz. 85, 121-151 (1928).

39) We 1 to n, F. A. and Morris, V. H., Lodging in oats and wheat. Ohio Agr. Exp. Sta. Bull. 471, pp. 88 (1931). 